UC-25 Metallurgy and Ceramics (TID-4500, 15th Ed.)

Contract No. W-7405-eng -92

\title{
DEVELOPMENT OF CORROSION-RESISTANT NIOBIUM-BASE ALLOYS
}

by

\author{
Daniel J. Maykuth \\ William D. Klopp \\ Robert I. Jaffee \\ Warren E. Berry \\ Frederick W. Fink
}

May 12, 1960

\author{
BATTELLE MEMORIAL INSTITUTE \\ $505 \mathrm{King}$ Avenue \\ Columbus 1, Ohio
}




\section{DISCLAIMER}

This report was prepared as an account of work sponsored by an agency of the United States Government. Neither the United States Government nor any agency Thereof, nor any of their employees, makes any warranty, express or implied, or assumes any legal liability or responsibility for the accuracy, completeness, or usefulness of any information, apparatus, product, or process disclosed, or represents that its use would not infringe privately owned rights. Reference herein to any specific commercial product, process, or service by trade name, trademark, manufacturer, or otherwise does not necessarily constitute or imply its endorsement, recommendation, or favoring by the United States Government or any agency thereof. The views and opinions of authors expressed herein do not necessarily state or reflect those of the United States Government or any agency thereof. 


\section{DISCLAIMER}

Portions of this document may be illegible in electronic image products. Images are produced from the best available original document. 


\section{TABLE OF CONTENTS}

Page

ABSTRACT . . . . . . . . . . . . . . . . . . . . . . . . . . 1

INTRODUCTION . . . . . . . . . . . . . . . . . . . . . . . . . . . . . 1

EXPERIMENTAL PROCEDURES . . . . . . . . . . . . . . . . . . . . . 2

Materials . . . . . . . . . . . . . . . . . . . . . . . 2

Alloy Preparation . . . . . . . . . . . . . . . . . . . . . . 4

Corrosion-Test Procedures . . . . . . . . . . . . . . . . . . 4

Specimen Preparation . . . . . . . . . . . . . . . 4

Test Conditions.... . . . . . . . . . . . . . . 5

Evaluation .. . . . . . . . . . . . . . . . 5

Hot-Hardness Testing. . . . . . . . . . . . . . . . . . 6

Tensile and Creep Testing. . . . . . . . . . . . . . . . . 6

EXPERIMENT AL RESULTS . . . . . . . . . . . . . . . . . . . . . . . 6

Alloy Preparation . . . . . . . . . . . . . . . . . . . . 6

Screening Alloys . . . . . . . . . . . . . . . 6

Scaleup Alloys . . . . . . . . . . . . . . . . 12

Metallography .. . . . . . . . . . . . . . 16

Corrosion Testing . . . . . . . . . . . . . . . . . . . 16

Appearance of Corroded Samples . . . . . . . . . . . . . . 19

Identification of Surface Oxides . . . . . . . . . . . . . 19

Corrosion Rates . . . . . . . . . . . . . . . . 20

Selective Attack. . . . . . . . . . . . . . . . . 33

Oxygen Contamination . . . . . . . . . . . . . . 35

Hydrogen Absorption . . . . . . . . . . . . . . . . . . . 35

Correlation of Corrosion-Test Results . . . . . . . . . . . . . 40

Theoretical Aspects. . . . . . . . . . . . . . . . 49

Hot Hardness . . . . . . . . . . . . . . . . . . . . 52

Tensile Properties . . . . . . . . . . . . . . . . . 65

Room Temperature .. . . . . . . . . . . . 68

Elevated Temperatures . . . . . . . . . . . . . 70

Creep Properties . . . . . . . . . . . . . . . . . . 77

CONCLUSIONS . . . . . . . . . . . . . . . . . . . . . . . . . . 88

REFERENCES . . . . . . . . . . . . . . . . . . . . . 89 


\title{
DEVELOPMENT OF CORROSION-RESISTANT NIOBIUM-BASE ALLOYS
}

\author{
Daniel J. Maykuth, William D. Klopp, Robert I. Jaffee, \\ Warren E. Berry, and Frederick W. Fink
}

\begin{abstract}
The hot-water corrosion resistance and mechanical properties of niobium and a number of its alloys were evaluated with a view toward determining their usefulness in pressurized-water thermal reactors.

Unalloyed niobium is rapidly attacked by 600 and $680 \mathrm{~F}$ water and $750 \mathrm{~F}$ steam. However, a number of alloying additions were found which markedly improve the corrosion resistance of niobium. Of these, binary and ternary combinations of chromium, molybdenum, titanium, vanadium, and zirconium were among the most effective. Many of these alloys show as low or lower weight gains than those obtained for Zircaloy-2 under similar test conditions. Most of the niobiumbase alloys tested for strength also show excellent resistance to creep at temperatures up to $1200 \mathrm{~F}$ under stresses through $20,000 \mathrm{psi}$.
\end{abstract}

\section{INTRODUCTION}

The objective of this research program was the development of a high-strength, low-neutron-absorption, corrosion-resistant niobium-base alloy suitable for use in pressurized-water thermal reactors. Concurrent niobium corrosion programs are also underway at Bettis and Knolls Atomic Power Laboratories.

Prior to the initiation of this work, relatively little information concerning the hotwater corrosion resistance of niobium or its alloys was available. Some work by Griess, et al. (1) indicated that unalloyed niobium showed moderately good resistance to $480 \mathrm{~F}$ water. Other reported data on the corrosion behavior in water of alloys containing niobium were those given by Ivanoff and Grigorovich(2). This work, however, was primarily concerned with zirconium-base alloys.

Work at Battelle(3) and elsewhere had shown that the hot-air oxidation resistance of niobium could be improved significantly by alloying. Moreover, principles were developed in the Battelle work by which the effectiveness of alloying elements on the air oxidation resistance of niobium could be explained or predicted. This was believed to be of great practical significance since both the air and water oxidation reactions were believed to be basically the same.

Chromium, molybdenum, titanium, tungsten, vanadium, and zirconium are foremost among the binary addition elements which are known to improve the hot-air oxidation resistance of niobium. Thus, it was of interest to determine the hot-water corrosion resistance of these binary-alloy systems to establish the suspected correlation between the hot-air and hot-water oxidation resistance of these alloys.

(1) References are at end of report. 
In addition a number of ternary niobium-base alloys were also evaluated. Initially, zirconium was most strongly favored as the major addition in the ternary alloys because of its low cross section and the high thermodynamic stability of its oxide. Later, as experimental results became available, several series of ternary alloys using vanadium as the major alloying addition were prepared for evaluation.

The experimental work on this program was actually begun with the corrosion testing of a group of wrought, commercial-purity niobium-base alloys which were available from the previous Battelle work(3). Additional alloys, using high-purity niobium as a base material, were made to screen and evaluate other compositions of interest as described above.

In the alloy-development work, emphasis was directed toward alloys which were fabricable and which would have a total calculated thermal-neutron-absorption cross section as low as possible, the cross section not to exceed the value of 2.8 barns per atom for an $18 \mathrm{w} / 0$ chromium-8 w/o nickel stainless steel. Although not a primary objective of the program, useful information was obtained concerning the melting and fabrication properties of the alloys.

\section{EXPERIMENTAL PROCEDURES}

\section{Materials}

All of the niobium and niobium-base alloys prepared for this study were made from 3 to 4-in. -diameter niobium ingots which had been purified to the analyses shown in Table 1 by double electron-beam zone melting. As indicated, the results of a check analysis at Battelle on one of these ingots were in good agreement with the supplied analysis. The alloying additions were of comparably high purity as indicated by the data of Table 2 .

Some evaluations were also conducted on a series of alloys made with commercially pure niobium of the following representative analysis:

\begin{tabular}{|c|c|c|c|}
\hline Impurity & Amount, ppm & Impurity & Amount, $\mathrm{ppm}$ \\
\hline Aluminum & 40 & Molybdenum & 100 \\
\hline Carbon & 50 & Nitrogen & 100 \\
\hline Calcium & 20 & Nickel & 60 \\
\hline Copper & 30 & Oxygen & 500 \\
\hline Iron & 200 & Silicon & 100 \\
\hline Hydrogen & 1 & Titanium & 50 \\
\hline Magnesium & $<10$ & Zirconium & 100 to 6000 \\
\hline Manganese & 10 & & \\
\hline
\end{tabular}

These alloys were made using alloy additions of the same or similar quality indicated in Table 2 for the higher purity niobium-base alloys. 
TABLE 1. ANALYSES AND HARDNESS OF DOUBLE ELECTRON-BEAM-MELTED NIOBIUM USED AS BASE MATERIAL FOR ALLOY INGOTS(a)

\begin{tabular}{|c|c|c|c|c|}
\hline \multirow[b]{3}{*}{ Element } & \multicolumn{4}{|c|}{ Analyses, ppm } \\
\hline & \multicolumn{2}{|c|}{$\begin{array}{c}\text { Lot } 405-599 \text { P37 } \\
{[\text { Bhn }(500-\mathrm{Kg} \text { Load })=55.7]}\end{array}$} & \multirow{2}{*}{$\begin{array}{c}\text { Lot } 405-599-162 \mathrm{A3} \\
\frac{[\mathrm{Bhn}(500-\mathrm{Kg} \text { Load })=59.3]}{\text { Supplier }}\end{array}$} & \multirow{2}{*}{$\begin{array}{c}\text { Lot } 405-645-168 \mathrm{A3} \\
\frac{[\mathrm{Bhn}(500-\mathrm{Kg} \text { Load })=51]}{\text { Supplier }}\end{array}$} \\
\hline & Battelle & Supplier & & \\
\hline & & & & $\therefore$ \\
\hline Aluminum & 20 & $<20$ & $<20$ & $<20$ \\
\hline Boron & - & $<1$ & $<1$ & $<1$ \\
\hline Carbon & 70 & 100 & $<30$ & $<30$ \\
\hline Cadmium & -- & $<1$ & -- & $<1$ \\
\hline Chromium & $<50$ & $<20$ & $<20$ & $<20$ \\
\hline Copper & $<10$ & 70 & -- & $<40$ \\
\hline Iron & $<30$ & $<100$ & $<100$ & $<100$ \\
\hline Magnesium & $<5$ & $<20$ & $<20$ & $<20$ \\
\hline Manganese & $<20$ & $<20$ & $<20$ & $<20$ \\
\hline Molybdenum & 300 & 40 & 20 & $<20$ \\
\hline Nutrogen & 70 & 103 & 50 & 40 \\
\hline NickeI & $<20$ & $<20$ & $<20$ & $<20$ \\
\hline Oxygen & 130 & 131 & 52 & 50 \\
\hline Lead & 30 & 40 & 50 & $<20$ \\
\hline Silicon & 30 & $<100$ & $<100$ & $<100$ \\
\hline Tin & - - & $<20$ & -- & $<20$ \\
\hline Tantalum & $<1500$ & 960 & 780 & 620 \\
\hline Titanium & $<30$ & $<150$ & $<150$ & $<150$ \\
\hline Vanadıum & -- & $<20$ & $<20$ & $<20$ \\
\hline Tungsten & - & $<300$ & 287 & $<300$ \\
\hline Zinc & -- & $<20$ & -- & $<20$ \\
\hline Zirconium & $<10$ & $<500$ & -- & $<500$ \\
\hline
\end{tabular}

(a) Niobium purity was $>998$ per cent, material and data recelved from the Wah Chang Corporatıon.

TABLE 2. ANALYSES OF ALLOYING ADDITIONS USED TO MAKE HIGH-PURITY NIOBIUM-BASE ALLOYS

\begin{tabular}{|c|c|c|c|c|c|c|c|c|c|c|c|c|c|c|c|}
\hline \multirow{2}{*}{$\begin{array}{l}\text { Base } \\
\text { Metal }\end{array}$} & \multirow{2}{*}{$\begin{array}{c}\text { Method of Preparation } \\
\text { or Source }\end{array}$} & \multicolumn{14}{|c|}{ Supplier's Analyses, ppm } \\
\hline & & Al & $\mathrm{C}$ & $\mathrm{Cr}$ & $\mathrm{Cu}$ & $\mathrm{Fe}$ & $\mathrm{H}$ & MIg & Mn & $N$ & 0 & $S_{1}$ & $T_{1}$ & V & $\mathrm{Cl}$ \\
\hline $\mathrm{Cl}_{\mathrm{l}}$ & Iodide process & 1 & 10 & - & -- & 1.5 & 1 & 1 & -- & 3 & 10 & -- & -- & -- & -- \\
\hline $\mathrm{Fe}$ & Electrolytic flake & $<30$ & 40 & $<30$ & $<10$ & -- & -- & $<5$ & 10 & - & 500 & 10 & $<10$ & $<50$ & -- \\
\hline Mo & Commercial, sintered rod & -- & 40 & -- & -- & -- & -- & - & -- & 40 & 70 & -- & -- & -- & -. \\
\hline Mlo & Vacuum -fusion purified & -- & $<30$ & $<5$ & 5 & $<50$ & $<1$ & $<20$ & $<5$ & $<10$ & $<10$ & $<20$ & $<10$ & -- & -- \\
\hline $\mathrm{N}_{1}$ & $\begin{array}{l}\text { Commercial, Nivac P } \\
\text { sheet }\end{array}$ & $<50$ & 26 & $<10$ & 40 & 130 & -- & -- & $<30$ & 1.2 & 58 & 20 & -- & - & -- \\
\hline $\mathrm{T}_{2}$ & Fused-salt electrolysis & $<300$ & 120 & $<50$ & $<60$ & $<50$ & 70 & $<10$ & 100 & 20 & 180 & 100 & -- & $<50$ & 600 \\
\hline V & Calcium reduction & $\cdots$ & - & -- & -. & -. & -- & -- & -- & -- & $25(a)$ & -. & -- & -- & -- \\
\hline $\mathrm{Zr}$ & Iodide process & $<35$ & 33 & -. & $<25$ & 27 & -- & $<10$ & -- & 8 & 300 & -. & $<25$ & -- & -. \\
\hline
\end{tabular}

(a) Estimated on the basis of lattice-parameter measurements. 


\section{Alloy Preparation}

All alloys were prepared by arc melting in either of two sizes, i. e., as 50-g "button" ingots or as 2-in.-diameter, consumable-electrode-melted ingots.

The button ingots were used to obtain a broad composition coverage for screening the alloys according to their $680 \mathrm{~F}$ water corrosion resistance and hot hardness. These ingots were inversion melted with a tungsten electrode, under an absolute helium pressure of $20^{\circ}$ to $30 \mathrm{~cm}$ of mercury, on a rocking, water-cooled copper crucible. Each alloy received a minimum of three, separate inversion-arc-melting operations.

The 2-1/2-1b ingots were prepared by double consumable-electrode arc melting under an absolute helium pressure of $25 \mathrm{~cm}$ of mercury. After the first melt, the ingots were sectioned longitudinally and joined end to end, by inert-atmosphere arc welding, to form a new electrode for the second melting operation.

Most of both types of alloy ingots were made using elemental charges of the desired addition metals. The only exceptions were for the ternary, 50-g alloy ingots containing combinations of niobium and vanadium with chromium or aluminum. In these instances, master alloys containing $51.4 \mathrm{w} / 0$ vanadium-48.6 w/o chromium and 40.6 w/o vanadium-59.4 w/o aluminum were first prepared by inert-electrode arc melting. These were then used in the alloy charges.

After melting, the hardnesses of all ingots were determined. Generally, for the 50-g-size screening alloy ingots, direct cold rolling to sheet was attempted where the as-cast hardnesses did not exceed a value of 150 VHN. Ingots of higher hardness were ground to a rectangular shape and fitted into a Type 304 stainless steel pack of welded construction for hot rolling to sheet at $1800 \mathrm{~F}$. Prior to rolling, the packs were evacuated and sealed. A parting compound, made up of a slurry of chromic oxide in water glass was used to prevent bonding of the alloys with the steel cover plates during rolling.

For the 2-1/2-1b scaleup alloy ingots, several fabrication techniques were investigated. These included direct hot forging of the unprotected, 2-in.-diameter ingots in air and forging and rolling of the as-cast stainless steel-clad ingots. Generally, the most satisfactory procedure involved longitudinal sectioning of the ingots into roughly rectangular slabs, of about 3/4-in. thickness, and cladding of these slabs in stainless steel packs of the same type used for the 50-g alloy ingots. The clad slabs were then rolled directly to sheet in air at $1800 \mathrm{~F}$.

After pack rolling, all of the alloys were cleaned by pickling, then grinding prior to vacuum annealing.

\section{Corrosion-Test Procedures}

\section{Specimen Preparation}

Corrosion specimens were cut from the annealed sheet. Specimens were shaper finished to a rectangular cross section. A minimum of 0.005 in. of metal was removed 
from each surface to insure that no surface contamination remained. Specimens were then measured, degreased, dried, and weighed prior to corrosion testing.

The specimens were inserted in individual Chromel A* wire baskets. Numbered stainless steel tags were attached to each basket to maintain specimen identity. The baskets were hung from stainless steel supports, and no effort was made to insulate them from the autoclave.

\section{Test Conditions}

The corrosion tests were conducted in static, l-liter-capacity autoclaves. The autoclaves and all auxiliary fittings and fixtures in contact with the water were AISI Type 316 stainless steel. An exception was the seal gasket which was made of "A" nickel.

Corrosion behavior was evaluated in 600 and $680 \mathrm{~F}$ degassed water and $750 \mathrm{~F}$, 1500-psi degassed steam. The test water was once distilled and then passed through a mixed-bed ion-exchange column. The specific resistivity of the starting water was in excess of 1 megohm-cm. The water was degassed for the 600 and $680 \mathrm{~F}$ tests by (1) boiling for $1 \mathrm{hr}$, (2) transferring quickly to the autoclave which was sealed, and (3) boiling off the excess water at $300 \mathrm{~F}$ to further purge the autoclave of entrapped air. In the $750 \mathrm{~F}$ steam tests, $100 \mathrm{ml}$ of water was added to the cold autoclave which was then sealed. The autoclave was opened to a vacuum pump three successive times with 5 -min intervals between pumpings. The autoclave temperature was then raised to $600 \mathrm{~F}$ and the excess steam was bled off periodically to keep the pressure at 1500 psi. Fresh water was added after each exposure period.

The schedule of corrosion-specimen examination was as follows:

(1) $600 \mathrm{~F}$ water: $7,14,28,42,56$ days and every 28 days thereafter

(2) $680 \mathrm{~F}$ water: $3,7,14,28,42,56$ days and every 28 days thereafter

(3) 750 F, 1500-psi steam: 1, 3, 7, 14, 21, 28, 42 days and every 14 days thereafter.

\section{Evaluation}

Corrosion behavior during the course of the experiment was evaluated on the basis of appearance and weight change of specimens. Specimens were brushed prior to weighing to remove any loose corrosion product. The microstructures of most specimens were examined when the corrosion tests were terminated. On selected samples, hardness traverses were made to determine the depth of contamination in the metal beneath the oxide film, and corrosion films were identified and hydrogen analyses were obtained. 
Hot-Hardness Testing

Hot-hardness measurements were conducted on annealed sheet specimens of each alloy in a vacuum atmosphere at $600,900,1200,1400$, and $1650 \mathrm{~F}$. Allowed heating times for the 600 and $900 \mathrm{~F}$ measurements were 60 and $45 \mathrm{~min}$, respectively, with $10-$ min periods being used for each of the higher temperatures. A sapphire indenter with a $730-\mathrm{g}$ load was used in all of the tests.

Leak rates for the vacuum system were checked before and after each run and were found not to exceed a value of $0.6 \mu$ per min for any run. As a check against possible contamination on heating, the room-temperature hardness of each sample was measured after as well as before heating to $1650 \mathrm{~F}$.

\title{
Tensile and Creep Testing
}

All tensile and creep tests were conducted on annealed sheet samples, approximately 45 mils thick, with a reduced section approximately $1 / 4$ in. wide and a gage length of 1 in.

All tensile tests were carried out at a crosshead speed of 0.02 in. per min, with testing at room temperature and $600 \mathrm{~F}$ being performed in air and tests at $1200 \mathrm{~F}$ being performed in helium.

The creep tests were all conducted in vacuum. Prior to testing, the reduced section of each sample was wrapped with niobium foil to minimize contamination.

\section{EXPERIMENTAL RESULTS}

\author{
Alloy Preparation
}

\section{Screening Alloys}

The compositions, cross sections, hardness, and fabrication data for all of the 50-g screening alloy ingots evaluated to date are listed in Table 3. This table includes data for the 22 binary and 9 ternary alloys prepared using commercial-purity niobium in the previous Battelle program. (3)

Generally, weight losses during melting of the alloys containing molybdenum, nickel, titanium, vanadium, and zirconium were quite low. However, the weight-loss data and subsequent analyses showed that almost all of the chromium and most of the aluminum and iron added to the alloy charges were lost during arc melting. 
TABLE 3. COMPOSITIONS, HARDNESSES, AND FABRICATION DATA FOR 50-G, INNERT-ELECTRODE ARC-MELTED NIOBIUM-BASE ALLOYS

\begin{tabular}{|c|c|c|c|c|c|c|c|c|}
\hline \multirow[b]{2}{*}{ Alloy } & \multirow{2}{*}{$\begin{array}{c}\text { Alloy Content } \\
\text { (Balance Niobium) }^{(a)} \text {, } \\
a / o \\
\end{array}$} & \multirow{2}{*}{$\begin{array}{l}\text { Weight Loss } \\
\text { in Melting, } \\
\text { per cent }\end{array}$} & \multirow{2}{*}{$\begin{array}{c}\text { Thermal-Neutron- } \\
\text { Absorption } \\
\text { Cross Section, } \\
\text { barns per atom }\end{array}$} & \multirow{2}{*}{$\begin{array}{l}\text { Fabrication } \\
\text { Procedure }^{(b)}\end{array}$} & \multirow{2}{*}{$\begin{array}{c}\text { Sheet } \\
\text { Quality }(c)\end{array}$} & \multirow{2}{*}{$\begin{array}{c}\text { Annealing } \\
\text { Temperature, } F\end{array}$} & \multicolumn{2}{|c|}{$\begin{array}{c}\text { Vickers Hardness } \\
\text { (10-Kg Load })\end{array}$} \\
\hline & & & & & & & As Cast & As Annealed \\
\hline \multicolumn{9}{|c|}{ Commercial-Purity (d) } \\
\hline-- & $100 \mathrm{Nb}$ & $-\cdot$ & 1.15 & $\mathrm{CR}$ & $\mathbf{E}$ & 2730 & 120 & 120 \\
\hline 138 & $10.5 \mathrm{ZI}$ & -- & 1.05 & HR & $G$ & 2730 & 187 & 199 \\
\hline 139 & $26.1 \mathrm{Zr}$ & -- & 0.90 & HR & G & 2730 & 212 & 266 \\
\hline 140 & $35.7 \mathrm{Zr}$ & -- & 0.81 & HR & $G$ & 2730 & 283 & 306 \\
\hline 141 & $45.7 \mathrm{Zr}$ & -- & 0.71 & $\mathrm{HR}$ & $G$ & 2730 & 289 & 302 \\
\hline 163 & $1.1 \mathrm{~W}$ & -- & 1.3 & $\mathrm{CR}$ & $G$ & 2730 & 147 & -- \\
\hline 164 & $4.7 \mathrm{~W}$ & -- & 2.0 & CR & $G$ & 2730 & 175 & -- \\
\hline 165 & $9.6 \mathrm{~W}$ & -- & 2.8 & HR & $G$ & 2730 & 230 & 266 \\
\hline 152 & 2. $45 \mathrm{Mo}$ & -- & 1.18 & $\mathrm{CR}$ & $G$ & 2730 & 128 & 126 \\
\hline 153 & $5.2 \mathrm{Mo}$ & -- & 1.21 & $\mathrm{CR}$ & $G$ & 2730 & 154 & 146 \\
\hline 154 & 7. $4 \mathrm{Mo}$ & -- & 1.26 & $C R$ & $\mathrm{~F}$ & 2730 & 175 & 205 \\
\hline 150 & $4.4 \mathrm{~V}$ & -- & 1.30 & CR & $G$ & 2730 & 152 & 143 \\
\hline 147 & $6.6 \mathrm{~V}$ & -- & 1.38 & $\mathrm{CR}$ & $G$ & 2730 & 168 & 169 \\
\hline 148 & $8.9 \mathrm{~V}$ & -- & 1.48 & $\mathrm{CR}$ & $G$ & 2730 & 196 & 191 \\
\hline 149 & $10.7 \mathrm{~V}$ & -- & 1. 54 & $\mathrm{CR}$ & $\mathrm{F}$ & 2730 & 209 & 210 \\
\hline 158 & $13.7 \mathrm{~V}$ & -- & 1.65 & $\mathrm{HR}$ & $G$ & 2730 & 264 & 281 \\
\hline 151 & $24.2 \mathrm{~V}$ & -- & 2.06 & $\mathrm{HR}$ & $G$ & 2730 & 285 & 314 \\
\hline 169 & $4.9 \mathrm{Fe}$ & -- & 1.22 & $\mathrm{CR}$ & G & 2730 & 167 & 127 \\
\hline 142 & $9.4 \mathrm{~T} 1$ & -- & 1.58 & $\mathrm{CR}$ & $E$ & 2730 & 123 & 127 \\
\hline 143 & $18.8 \mathrm{Tl}$ & -- & 2.02 & $\mathrm{CR}$ & $E$ & 2730 & 145 & 154 \\
\hline 144 & $24.3 \mathrm{Tl}$ & -- & 2.26 & $\mathrm{CR}$ & $\mathbf{E}$ & 2730 & 145 & 162 \\
\hline 145 & $30.5 \mathrm{~T}_{1}$ & -- & 2.58 & $\mathrm{CR}$ & $\mathrm{E}$ & 2730 & 151 & 160 \\
\hline 146 & $33.8 \mathrm{~T} 1$ & -- & 2.72 & $\mathrm{CR}$ & $\mathrm{E}$ & 2730 & 155 & 169 \\
\hline 175 & $12.0 \mathrm{~T} 1-0.5 \mathrm{Cr}$ & -- & 1.72 & $\mathrm{HR}$ & $\mathbf{E}$ & 2730 & 136 & 240 \\
\hline 176 & $20.2 \mathrm{~T} 1-2.1 \mathrm{Cr}$ & -- & 2.12 & $\mathrm{HR}$ & $E$ & 2730 & 192 & 235 \\
\hline 177 & $28.2 \mathrm{~T} 1-6.1 \mathrm{Cr}$ & -- & 2.56 & $\mathrm{HR}$ & $G$ & 2730 & 230 & 348 \\
\hline
\end{tabular}


TABLE 3. (Continued)

\begin{tabular}{|c|c|c|c|c|c|c|c|c|}
\hline \multirow[b]{2}{*}{ Alloy } & \multirow{2}{*}{$\begin{array}{c}\text { Alloy Cortent } \\
\text { (Balance Niobium) }^{(a)} \text {, } \\
\text { a/o }\end{array}$} & \multirow{2}{*}{$\begin{array}{l}\text { Weight Loss } \\
\text { in Melting, } \\
\text { per cent }\end{array}$} & \multirow{2}{*}{$\begin{array}{c}\text { Thermal-Neutron- } \\
\text { Absorption } \\
\text { Cross Section, } \\
\text { barns per atom }\end{array}$} & \multirow{2}{*}{$\begin{array}{l}\text { Fabrication } \\
\text { Procedure(b) }\end{array}$} & \multirow{2}{*}{$\begin{array}{c}\text { Sheet } \\
\text { Quality }(c)\end{array}$} & \multirow{2}{*}{$\begin{array}{c}\text { Anncaling } \\
\text { Temperature, } F \\
\end{array}$} & \multicolumn{2}{|c|}{$\begin{array}{l}\text { Vickers Hardness } \\
\text { (10-Kg Load) }\end{array}$} \\
\hline & & & & & & & As Cast & As Anne aled \\
\hline \multicolumn{9}{|c|}{$\frac{\text { Commercial-Purity }(\mathrm{d})}{\text { (Continued) }}$} \\
\hline 172 & $12 \mathrm{Ti}-4.2 \mathrm{Mo}$ & -- & 1.78 & $\mathrm{HR}$ & $G$ & 2730 & 171 & 177 \\
\hline 173 & 17.4 Ti-6. $2 \mathrm{Mo}$ & -- & 2.06 & HR & G & 2730 & 192 & 227 \\
\hline 174 & $23.1 \mathrm{Ti}-7.8 \mathrm{Mo}$ & -- & 2.35 & $\mathrm{HR}$ & G & 2730 & 206 & 260 \\
\hline 178 & $10.4 \mathrm{Ti}-5.0 \mathrm{~V}$ & $\cdots$ & 1.57 & $\mathrm{HR}$ & $\mathrm{E}$ & 2730 & 175 & 268 \\
\hline 179 & $16.1 \mathrm{Ti}-8.4 \mathrm{~V}$ & -- & 1.80 & $\mathrm{HR}$ & G & 2730 & 199 & 262 \\
\hline 180 & $22.6 \mathrm{Ti}-11.0 \mathrm{~V}$ & $\cdots$ & 2.05 & $\mathrm{HR}$ & $G$ & 2730 & 243 & 287 \\
\hline \multicolumn{9}{|c|}{ High-Purity } \\
\hline N1 & $100 \mathrm{Nb}$ & $\cdots$ & 1.15 & $\mathrm{CR}$ & E & 2190 & 95 & 105 \\
\hline $\mathrm{N} 40$ & $100 \mathrm{Nb}$ & -- & 1.15 & $\mathrm{CR}$ & $\mathrm{E}$ & 2190 & 101 & 109 \\
\hline N44 & $100 \mathrm{Nb}$ & -- & 1.15 & $\mathrm{CR}$ & $\mathrm{E}$ & 2190 & 93 & 110 \\
\hline N56 & $100 \mathrm{Nb}$ & -- & 1.15 & $\mathrm{CR}$ & E & 2190 & 93 & 94 \\
\hline N2 & $1.1 \mathrm{Zr}$ & 0 & 1.14 & $\mathrm{CR}$ & G & 2190 & 129 & 96 \\
\hline N3 & $2.2 \mathrm{Zr}$ & 0.3 & 1.13 & HR & G & 2190 & 151 & -- \\
\hline N4 & $5 \mathrm{Zr}(\mathrm{e})$ & 0 & 1.10 & HR & G & 2730 & 173 & 165 \\
\hline N5 & $10.2 \mathrm{Zr}$ & 0 & 1.05 & $\mathrm{HR}$ & G & 2730 & 207 . & 192 \\
\hline $\mathrm{N} 41$ & $25 \mathrm{ZN}^{(\mathrm{e})}$ & 0.1 & 0.91 & $\mathrm{HR}$ & $G$ & 2730 & 264 & -- \\
\hline $\mathrm{N} 42$ & $35 \mathrm{ZI}(\mathrm{e})$ & 0.2 & 0.81 & $\mathrm{HR}$ & $\mathrm{G}$ & 2730 & 279 & -- \\
\hline N6 & $40 \mathrm{Zn}(e)$ & 0 & 0.76 & HR & $G$ & 2730 & 276 & 293 \\
\hline $\mathrm{N} 43$ & $45 \mathrm{Zn}(\mathrm{e})$ & 0.1 & 0.72 & $\mathrm{HR}$ & $G$ & 2730 & 266 & -- \\
\hline N8 & $65 \mathrm{ZI}(\mathrm{e})$ & 0 & 0.52 & $\mathrm{HR}$ & $G$ & 2730 & 212 & 234 \\
\hline N9 & $75 \mathrm{Zr}(\mathrm{e})$ & 0 & 0.42 & $\mathrm{HR}$ & $G$ & 2730 & 193 & 195 \\
\hline $\mathrm{N} 10$ & $90 \mathrm{Zr}(\mathrm{e})$ & 0 & 0.27 & $\mathrm{HR}$ & $\mathrm{G}$ & 2730 & 304 & 435 \\
\hline $\mathrm{N} 11$ & $3.2 \mathrm{Ti}$ & 0.4 & 1.30 & $\mathrm{CR}$ & $\mathbf{E}$ & 2190 & 98 & 83 \\
\hline $\mathrm{N} 12$ & $10.5 \mathrm{Ti}$ & 2.0 & 1. 60 & $\mathrm{CR}$ & $\mathbf{E}$ & 2190 & 122 & 106 \\
\hline $\mathrm{N} 13$ & $25 \mathrm{Ti}^{(\mathrm{e})}$ & 2.4 & 2.30 & $\mathrm{CR}$ & $\mathrm{E}$ & 2190 & 146 & 123 \\
\hline N14 & $<0.02 \mathrm{Cr}$ & 0.8 & 1.15 & $C R$ & $E$ & 2190 & 84 & 74 \\
\hline N15 & $0.5 \mathrm{Cr}$ & 5.6 & 1.16 & $C R$ & $G$ & 2190 & 90 & 78 \\
\hline N48 & $0.5 \mathrm{Cr}$ & 5.2 & 1.16 & $\mathrm{CR}$ & G & 2190 & 84 & 113 \\
\hline
\end{tabular}


TABLE 3. (Continued)

\begin{tabular}{|c|c|c|c|c|c|c|c|c|}
\hline \multirow[b]{2}{*}{ Alloy } & \multirow{2}{*}{$\begin{array}{c}\text { Alloy Content } \\
\begin{array}{c}\text { (Balance Niobium) }^{(a)} \text {, } \\
\text { a/o }\end{array}\end{array}$} & \multirow{2}{*}{$\begin{array}{l}\text { Weight Loss } \\
\text { in Mclting, } \\
\text { per cont }\end{array}$} & \multirow{2}{*}{$\begin{array}{c}\text { Thermal-Neutron- } \\
\text { Absorption } \\
\text { Cross Section, } \\
\text { barns per atom }\end{array}$} & \multirow{2}{*}{$\begin{array}{l}\text { Fabrication } \\
\text { Procedure(b) }\end{array}$} & \multirow{2}{*}{$\begin{array}{c}\text { Sheet } \\
\text { Quality (c) }\end{array}$} & \multirow{2}{*}{$\begin{array}{c}\text { Annealing } \\
\text { Temperature, F }\end{array}$} & \multicolumn{2}{|c|}{$\begin{array}{l}\text { Vickers Hardness } \\
\text { (10-Kg Load) }\end{array}$} \\
\hline & & & & & & & $\widetilde{\text { As Cast }}$ & As Annealed \\
\hline & & & & $\frac{\text { High-Purity }}{\text { (Continued) }}$ & & & & \\
\hline $\mathrm{N} 45$ & $<0.08 \mathrm{Fe}$ & 0.6 & 1.15 & $\mathrm{CR}$ & G & 2190 & 89 & 96 \\
\hline $\mathrm{N} 46$ & $0.3 \mathrm{Fe}$ & 2.8 & 1.16 & HR & $G$ & 2190 & 116 & 107 \\
\hline $\mathrm{N} 47$ & $10 \mathrm{Fe}^{(\mathrm{e})}$ & 3.2 & 1.28 & $\mathrm{HR}$ & G & 2190 & 238 & 232 \\
\hline N57 & $1 \mathrm{Ce}(\mathrm{e})$ & 1.7 & 1. 13 & $\mathrm{CR}$ & G & 2190 & 73 & 71 \\
\hline N59 & $1 Y(e)$ & 1.2 & 1.15 & $\mathrm{CR}$ & G & 2190 & 86 & 94 \\
\hline N60 & $5 \mathrm{Y}(\mathrm{e})$ & 5.0 & 1.16 & $\mathrm{CR}$ & G & 2190 & 67 & 109 \\
\hline N61 & $1 \mathrm{Ni}(e)$ & 0.2 & 1.18 & HR & G & 2190 & 140 & 144 \\
\hline N62 & $2.5 \mathrm{Ni}(\mathrm{e})$ & 1.2 & 1.23 & $\mathrm{HR}$ & $F$ & 2190 & 192 & 171 \\
\hline N63 & $5 \mathrm{Ni}(e)$ & 0.6 & 1. 32 & $\mathrm{HR}$ & $\mathrm{P}$ & 2190 & 223 & 186 \\
\hline N64 & $1 \mathrm{Pd}(\mathrm{e})$ & 0.4 & 1.21 & $\mathrm{CR}$ & G & 2190 & 107 & 134 \\
\hline N16 & $1.6 \mathrm{~V}$ & 0.8 & 1.18 & $\mathrm{CR}$ & $G$ & 2190 & 106 & 91 \\
\hline N81 & $5 \mathrm{~V}(\mathrm{e})$ & 0 & 1.34 & $\mathrm{CR}$ & G & 2190 & 159 & 151 \\
\hline $\mathrm{N} 49$ & $2 \mathrm{~V}-2.5 \mathrm{Ti}$ & 2.4 & 1.34 & $\mathrm{CR}$ & G & 2190 & 115 & 118 \\
\hline N50 & $2 \mathrm{~V}-2.3 \mathrm{Mo}$ & 0.6 & 1.29 & $\mathrm{CR}$ & $G$ & 2190 & 127 & 134 \\
\hline N51 & $2.2 \mathrm{~V}-0.54 \mathrm{Fe}$ & 1.6 & 1.24 & $\mathrm{CR}$ & G & 2190 & 136 & 134 \\
\hline N52 & $2.2 \mathrm{~V}-0.87 \mathrm{Ni}$ & 1.4 & 1.24 & $\mathrm{HR}$ & G & 2190 & 177 & 174 \\
\hline $\mathrm{N} 53$ & $1.8 \mathrm{~V}-<0.02 \mathrm{Cr}$ & 2.2 & 1.19 & $\mathrm{CR}$ & G & 2190 & 106 & 105 \\
\hline N54 & $1.8 \mathrm{~V}-0.14 \mathrm{Al}$ & 1.0 & 1.19 & $\mathrm{CR}$ & G & 2190 & 105 & 109 \\
\hline N55 & $2.5 \mathrm{~V}-2.5 \mathrm{ZN}(\mathrm{e})$ & 0.6 & 1.22 & $\mathrm{HR}$ & $G$ & 2190 & 149 & 146 \\
\hline N65 & $5 \mathrm{~V}-2.5 \mathrm{Ti}^{(e)}$ & 0.5 & 1.49 & $\mathrm{CR}$ & $G$ & 2190 & 150 & 150 \\
\hline N66 & $5 \mathrm{~V}-2.5 \mathrm{Mo}(\mathrm{e})$ & 0.3 & 1.38 & $\mathrm{HR}$ & $G$ & 2190 & 144 & 158 \\
\hline N67 & $5 \mathrm{~V}-2.5 \mathrm{Fe}(\mathrm{e})$ & 0.1 & 1.38 & $\mathrm{HR}$ & $G$ & 2190 & 177 & 169 \\
\hline N68 & $5 \mathrm{~V}-2.5 \mathrm{Cr}(\mathrm{e})$ & 0.4 & 1.39 & $\mathrm{CR}$ & $G$ & 2190 & 149 & 149 \\
\hline N69 & $5 \mathrm{~V}-2.5 \mathrm{Ni}(\mathrm{e})$ & 0.7 & 1.48 & $\mathrm{HR}$ & G & 2190 & 232 & 211 \\
\hline N70 & $5 \mathrm{~V}-2.5 \mathrm{Al}(\mathrm{e})$ & 1.3 & 1. 32 & $C R$ & $G$ & 2190 & 150 & 144 \\
\hline N71 & $2.5 \mathrm{~V}-0.5 \mathrm{C}(\mathrm{e})$ & 0.4 & 1.24 & HR & G & 2190 & 153 & 130 \\
\hline $\mathrm{N} 72$ & $5 \mathrm{~V}-0.5 \mathrm{C}(\mathrm{e})$ & 0 & 1.34 & $\mathrm{HR}$ & G & 2190 & 198 & 163 \\
\hline
\end{tabular}


TABLE 3. (Continued)

\begin{tabular}{|c|c|c|c|c|c|c|c|c|}
\hline \multirow[b]{2}{*}{ Alloy } & \multirow{2}{*}{$\begin{array}{c}\text { Alloy Content } \\
\text { (Balance Niobium) }^{(a)} \\
\mathrm{a} / 0\end{array}$} & \multirow{2}{*}{$\begin{array}{l}\text { Weight Loss } \\
\text { in Melting, } \\
\text { per cent } \\
\end{array}$} & \multirow{2}{*}{$\begin{array}{c}\text { Thermal-Neutron- } \\
\text { Absorption } \\
\text { Cross Section, } \\
\text { barns per atom }\end{array}$} & \multirow{2}{*}{$\begin{array}{l}\text { Fabrication } \\
\text { Procedure(b) }\end{array}$} & \multirow{2}{*}{$\begin{array}{c}\text { Sheet } \\
\text { Quality }(c)\end{array}$} & \multirow{2}{*}{$\begin{array}{c}\text { Annealing } \\
\text { Temperature, F }\end{array}$} & \multicolumn{2}{|c|}{$\begin{array}{l}\text { Vickers Hardness } \\
\text { (10-Kg Load) }\end{array}$} \\
\hline & & & & & & & As Cast & As Annealed \\
\hline & & & & $\frac{\text { h-Purity }}{\text { ntinued) }}$ & & & & \\
\hline N73 & $2.5 \mathrm{~V}-0.25 \mathrm{Ti}-0.5 \mathrm{~d}(\mathrm{e})$ & 0.3 & 1.29 & HR & G & 2190 & 162 & 161 \\
\hline N74 & $5 \mathrm{~V}-0.25 \mathrm{Ti}-0.5 \mathrm{\alpha}(\mathrm{e})$ & 0 & 1.41 & HR & $G$ & 2190 & 179 & 186 \\
\hline N75 & $2.5 \mathrm{~V}-0.25 \mathrm{Zr}-0.5 \mathrm{~d}(\mathrm{e})$ & 0 & 1.24 & $\mathrm{HR}$ & $G$ & 2190 & 165 & 158 \\
\hline N76 & $5 \mathrm{~V}-0.25 \mathrm{Zr}-0.5 \mathrm{~d}(\mathrm{e})$ & 0.1 & 1.34 & $\mathrm{HR}$ & G & 2190 & 188 & 163 \\
\hline N77 & $2.5 \mathrm{~V}-0.5 \mathrm{Ti}-0.5 \mathrm{C}(\mathrm{e})$ & 0.3 & 1.30 & HR & $G$ & 2190 & 150 & 127 \\
\hline N78 & $5 \mathrm{~V}-0.5 \mathrm{Ti}-0.5 \mathrm{C}(\mathrm{e})$ & 0.3 & 1.42 & HR & $G$ & 2190 & 199 & 163 \\
\hline N79 & $2.5 \mathrm{~V}-0.5 \mathrm{Z}_{\mathrm{I}-0.5 \mathrm{C}(\mathrm{e})}$ & 0 & 1.24 & HR & $G$ & 2190 & 160 & 163 \\
\hline N80 & $5 \mathrm{~V}-0.5 \mathrm{Zr}-0.5 \mathrm{C}(\mathrm{e})$ & 0 & 1.34 & HR & G & 2190 & 203 & 198 \\
\hline $\mathrm{N} 17$ & $2.3 \mathrm{Zr}-4.0 \mathrm{~V}$ & 1.7 & 1.26 & $\mathrm{HR}$ & $G$ & 2190 & 101 & 168 \\
\hline $\mathrm{N} 18$ & $25 \mathrm{Zr}-5 \mathrm{~V}(\mathrm{e})$ & 0.2 & 1.10 & HR & $G$ & 2730 & 283 & 286 \\
\hline N19 & $35 \mathrm{Zr}-5 \mathrm{~V}(\mathrm{e})$ & 0.1 & 1.00 & HR & $G$ & 2730 & 297 & 313 \\
\hline $\mathrm{N} 20$ & $45 \mathrm{Zr}-5 \mathrm{~V}(\mathrm{e})$ & 0.1 & 0.90 & $\mathrm{HR}$ & $G$ & 2730 & 304 & 321 \\
\hline N21 & $10.9 \mathrm{Zr}-5.1 \mathrm{Ti}$ & 1.8 & 1.24 & HR & $G$ & 2730 & 202 & 210 \\
\hline N22 & $25 \mathrm{Zr}-5 \mathrm{Ti}(\mathrm{e})$ & 1.1 & 1.10 & HR & $G$ & 2730 & 258 & 271 \\
\hline $\mathrm{N} 23$ & $25 \mathrm{Zr}-15 \mathrm{Ti}(\mathrm{e})$ & 0.6 & 1.56 & HR & $G$ & 2730 & 253 & 277 \\
\hline $\mathrm{N} 24$ & $25 \mathrm{Zr}-25 \mathrm{Ti}(\mathrm{e})$ & 0.4 & 2.04 & HR & $G$ & 2730 & 253 & 265 \\
\hline N25 & $35 \mathrm{Zr}-5 \mathrm{Ti}(\mathrm{e})$ & 1.0 & 1.00 & HR & $G$ & 2730 & 262 & 274 \\
\hline N26 & $35 \mathrm{Zr}-15 \mathrm{Ti}(\mathrm{e})$ & 0.8 & 1.50 & $\mathrm{HR}$ & $G$ & 2730 & 264 & 306 \\
\hline N28 & $45 \mathrm{Zr}-5 \mathrm{Ti}(\mathrm{e})$ & 0.6 & 0.92 & $\mathrm{HR}$ & $G$ & 2730 & 253 & 280 \\
\hline $\mathrm{N} 29$ & $10 \mathrm{Zr}-5 \mathrm{Mo}(\mathrm{e})$ & 0.3 & 1.13 & $\mathrm{HR}$ & $G$ & 2730 & 236 & 244 \\
\hline N30 & $35 \mathrm{Zr}-5 \mathrm{Md}(\mathrm{e})$ & 0.6 & 0.88 & HR & $G$ & 2730 & 323 & 325 \\
\hline N31 & $45 \mathrm{Zr}-5 \mathrm{Md}(\mathrm{e})$ & 0.2 & 0.78 & HR & $G$ & 2730 & 321 & 313 \\
\hline N32 & $35 \mathrm{Zr}-5 \mathrm{Al}(\mathrm{e})$ & 0.4 & 0.76 & HR & G & 2730 & 325 & 329 \\
\hline N33 & $35 \mathrm{Zr}-15 \mathrm{Al}(\mathrm{e})$ & 0.2 & 0.68 & HR & NG & -- & 429 & -- \\
\hline N34 & $45 \mathrm{Zr}-5 \mathrm{Al}(\mathrm{e})$ & 0 & 0.67 & $\mathrm{HR}$ & G & 2730 & 311 & 329 \\
\hline N35 & $10 \mathrm{Zr}-5 \mathrm{Cr}(\mathrm{e})$ & 2.7 & 1.14 & HR & G & 2730 & 194 & 219 \\
\hline N36 & $35 \mathrm{Zr}-5 \mathrm{Cr}(\mathrm{e})$ & 1.0 & 0.99 & $\mathrm{HR}$ & NG & -- & 312 & -- \\
\hline N37 & $45 \mathrm{Zr}_{\mathrm{r}}-5 \mathrm{Cr}^{(\mathrm{e})}$ & 0.5 & 0.93 & $\mathrm{HR}$ & $G$ & 2730 & 330 & 332 \\
\hline N38 & $10 \mathrm{Zr}-5 \mathrm{Fe}(\mathrm{e})$ & 1.2 & 1.12 & $\mathrm{HR}$ & $G$ & 2730 & 266 & 341 \\
\hline N39 & $45 \mathrm{Zr}-5 \mathrm{Fe}(\mathrm{e})$ & 0 & 0.78 & $\mathrm{HR}$ & NG & -. & 348 & -- \\
\hline
\end{tabular}

Footnotes appear on following page. 
Footnotes for Table 3.

(a) By chemical analysis unless otherwise indicated.

(b) CR designates cold rolling to 45-mil-thick strip, with interstage annealing at 75 per cent reduction, HR designates hot rolling in evacuated stainless steel pack at $1800 \mathrm{~F}$ to $45-\mathrm{mll}$-thick strip.

(c) E desıgnates excellent, $G$ desıgnates good, $F$ desıgnates fair, NG desıgnates no good.

(d) Alloys made in earlier Battelle program, see BMI-1317, "Oxidation and Contamination Reactions of Niobium and Niobium Alloys", February 3, 1959.

(e) Nominal composition. 
The earlier Battelle work indicated that binary additions to niobium of titanium, molybdenum, zirconium, vanadium, iron, and tungsten (in the approximate order listed) resulted in alloys of increasingly higher hardnesses. This same work indicated the approximate limiting alloy contents for good cold workability in 50-g binary-alloy ingots were as follows:

Titanium
Vanadium
Molybdenum
Zirconium

Titanium Molybdenum Zirconium

$$
\begin{array}{r}
>33.8 \mathrm{a} / \mathrm{o} \\
10.7 \mathrm{a} / \mathrm{o} \\
\sim 7.5 \mathrm{a} / \mathrm{o} \\
<10.5 \mathrm{a} / \mathrm{o}
\end{array}
$$

$\begin{array}{ll}\text { Iron } & \sim 5 \mathrm{a} / \mathrm{o} \\ \text { Tungsten } & \sim 5 \mathrm{a} / \mathrm{o} \\ \text { Chromium } & <3 \mathrm{a} / \mathrm{o}\end{array}$

In the present work, the alloy limits for good cold workability were more closely defined for binary niobium-zirconium and niobium-iron alloys at levels of about $I$ per cent each for both alloying elements.

The only alloys which could not be fabricated to useful sheet by cold- or hot-pack rolling were those ternaries containing 35 a/o zirconium- 15 a/o aluminum, 35 a/o zirconium-5 a/o chromium, and 45 a/o zirconium-5 a/o iron.

After fabrication and cleanup, each alloy was vacuum annealed. Initially, $1 \mathrm{hr}$ at $2730 \mathrm{~F}(1500 \mathrm{C})$ was used as the annealing treatment as in the previous work. Later, however, the annealing temperature was dropped to $2190 \mathrm{~F}(1200 \mathrm{C})$ for alloys containing a total of 10 per cent additions or less in order to keep the recrystallized grain sizes as small as possible.

As indicated in Table 3, four unalloyed 50-g ingots of niobium were prepared to act as control samples for the alloys. The niobium for each of the unalloyed ingots was taken from the same lot of electron-beam-melted material (Lot 405-599-P37) which had an as-received hardness of 81 VHN. Alloys N1, N40, and N44 were each melted three times, and Alloy N56 was melted twice. In addition, separate niobium getter buttons were melted prior to each melting operation for Alloys N44 and N56. In spite of these precautions, the hardnesses of all four arc-melted samples were 20 to 30 VHN higher than that of the base material, indicating that some contamination had occurred during melting.

\section{$\underline{\text { Scaleup Alloys }}$}

Table 4 lists the compositions, cross sections, hardnesses, and fabrication data for the fourteen 2-1/2-1b alloy ingots which were prepared to obtain mechanical-property data on selected compositions of interest.

In order to obtain comparative data for unalloyed niobium, a portion of one asreceived, electron-beam-melted ingot (Lot 405-599-P37) was cold rolled directly from the 4-in. ingot to 70-mil-thick sheet. After degreasing and pickling, this material was vacuum annealed for $1 \mathrm{hr}$ at $2730 \mathrm{~F}$. Analyses of this material for interstitial content are given in Table 5. Comparison of these data with those for the as-received material (Table 1) shows that about $70 \mathrm{ppm}$ oxygen pickup occurred as a result of contamination during the cold rolling and/or vacuum annealing of this material. 
TABLE 4. COMPOSITIONS, HARDNESSES, AND FABRICATION DATA FOR 2-1/2-LB, CONSUMABLE-ELECTRODE ARC-MELTED ALLOY INGOTS

\begin{tabular}{|c|c|c|c|c|c|c|}
\hline Alloy & $\frac{\text { Alloy Content (E }}{\text { Charged }}$ & $\frac{\text { ice Niobium), a/o }}{\text { Analyzed }}$ & $\begin{array}{c}\text { Thermal- } \\
\text { Neutron- } \\
\text { Absorption } \\
\text { Cross Section, } \\
\text { barns per atom }\end{array}$ & $\begin{array}{l}\text { As-Cast } \\
\text { Hardness } \\
\text { (1500-Kg } \\
\text { Load), } \\
\text { Bhn }\end{array}$ & Fabrication Conditions $(\mathrm{a})$ & Results \\
\hline NL -1 & $45.9 \mathrm{Zr}$ & - & 0.70 & 255 & $\begin{array}{l}\text { Forged in SS at } 1950 \mathrm{~F} \\
\text { and rolled in SS at } \\
1800 \mathrm{~F}\end{array}$ & $\begin{array}{l}\text { Partıal liquation, } \\
\text { sheet no good }\end{array}$ \\
\hline NL -2 & $13.1 \mathrm{~V}$ & $12.6 \mathrm{~V}$ & 1.61 & 201 & Ditto & $\begin{array}{l}\text { Some edge crack- } \\
\text { ing, fair quality } \\
\text { sheet }\end{array}$ \\
\hline NL -3 & $7.5 \mathrm{Mo}$ & $7.2 \mathrm{Mo}$ & 1.25 & 160 & Ditto & Ditto \\
\hline NL -4 & $45.1 \mathrm{Zr}-5.0 \mathrm{~T} 1$ & $46.8 \mathrm{Zr}-5.1 \mathrm{Tl}$ & 0.92 & 238 & $\begin{array}{l}\text { (1) Forged in air at } \\
2200 \mathrm{~F}\end{array}$ & $\begin{array}{l}\text { (1) Ingot cracked } \\
\text { in initial } \\
\text { upsetting }\end{array}$ \\
\hline \multirow[t]{2}{*}{ NL -5} & $44.8 \mathrm{Zr}-3.0 \mathrm{~V}$ & - & 0.83 & 272 & $\begin{array}{l}\text { (1) Forged in air at } \\
2200 \mathrm{~F}\end{array}$ & $\begin{array}{l}\text { (1) Ingot cracked } \\
\text { in initial } \\
\text { upsetting }\end{array}$ \\
\hline & & & & & $\begin{array}{l}\text { (2) Ingot slabs rolled } \\
\text { In SS at } 1800 \mathrm{~F}\end{array}$ & $\begin{array}{l}\text { (2) No good, } \\
\text { slices fragmented } \\
\text { severely }\end{array}$ \\
\hline$N L-5 R$ & $45.0 \mathrm{Zr}-3.1 \mathrm{~V}$ & -- & 0.83 & 258 & $\begin{array}{l}\text { Ingot slabs rolled in SS } \\
\text { at } 1800 \mathrm{~F}\end{array}$ & $\begin{array}{l}\text { No good, slices } \\
\text { fragmented } \\
\text { severely }\end{array}$ \\
\hline $\mathrm{NL}-6$ & $16.4 \mathrm{~T} 1-8.3 \mathrm{Mo}$ & $18.8 \mathrm{~T} 1-8.7 \mathrm{Mo}$ & 215 & 198 & $\begin{array}{l}\text { (1) Forged in air at } \\
2200 \mathrm{~F}\end{array}$ & $\begin{array}{l}\text { (1) Ingot cracked } \\
\text { in initial } \\
\text { upsetting }\end{array}$ \\
\hline $\mathrm{NL}-8$ & $9.9 \mathrm{~V}-9.9 \mathrm{Zr}$ & $9.4 \mathrm{~V}-9.9 \mathrm{Zr}$ & 1. 39 & 228 & Ditto & $\begin{array}{r}\text { Rolled to good } \\
\text { quality sheet }\end{array}$ \\
\hline NL -9 & $12.8 \mathrm{~V}-6.3 \mathrm{Zr}$ & $11.4 \mathrm{~V}-5.7 \mathrm{Zr}$ & 1.50 & 237 & Ditto & Ditto \\
\hline NL -10 & $9.9 \mathrm{~T} 1-6.7 \mathrm{Cr}$ & $9.6 \mathrm{~T}_{1}-3.3 \mathrm{Cr}_{\mathrm{r}}$ (b) & 1.75 & 196 & Ditto & Ditto \\
\hline $\mathrm{NL}-11$ & $7.6 \mathrm{~V}$ & $7.6 \mathrm{~V}$ & 1.44 & 168 & Ditto & $\begin{array}{l}\text { Rolled to very } \\
\text { good quality } \\
\text { sheet }\end{array}$ \\
\hline NL -12 & $8.8 \mathrm{~V}-0.22 \mathrm{~N}$ & $8.7 \mathrm{~V}-0.26 \mathrm{~N}^{(\mathrm{c})}$ & 1.47 & 182 & Ditto & Ditto \\
\hline NL -13 & $7.4 \mathrm{~V}-2.5 \mathrm{Tl}$ & $7.3 \mathrm{~V}-2.4 \mathrm{Tl}$ & 1.55 & 172 & Ditto & Ditto \\
\hline NL -14 & $7.5 \mathrm{~V}-2.5 \mathrm{Mo}$ & $7.6 \mathrm{~V}-2.3 \mathrm{Mo}$ & 1. 48 & 185 & Ditto & Ditto \\
\hline
\end{tabular}

(d) SS designates evacuated stainless steel pack.

(b) Chromum content variable, see text.

(c) Equvalent to $0.040 \mathrm{w} / \mathrm{o}$ nitrogen. 
TABLE 5. ANALYSES OF SELECTED NIOBIUM-BASE ALLOYS FOR INTERSTITIAL CONT AMINANTS ${ }^{(a)}$

\begin{tabular}{|c|c|c|c|c|c|}
\hline \multirow[b]{2}{*}{ Alloy } & \multirow{2}{*}{$\begin{array}{c}\text { Alloy Content } \\
\text { (Balance Niobium), } \\
a / 0\end{array}$} & \multicolumn{4}{|c|}{ Interstitial Content, ppm } \\
\hline & & Oxygen & Nitrogen & Carbon & Hydrogen \\
\hline $\mathrm{TP}-37$ & $100 \mathrm{Nb}^{(\mathrm{b})}$ & 200 & 90 & 70 & 3 \\
\hline NL-2 & $12.6 \mathrm{~V}$ & 360 & 140 & 180 & 7 \\
\hline$N L-3$ & $7.2 \mathrm{Mo}$ & 440 & 90 & 60 & 19 \\
\hline NL-4 & $46.8 \mathrm{Zr}-5.1 \mathrm{Ti}$ & -- & 70 & 60 & -- \\
\hline NL-6 & $18.8 \mathrm{Ti}-8.7 \mathrm{Mo}$ & 200 & 100 & 70 & 11 \\
\hline NL-7 & $11.2 \mathrm{Ti}-3.2 \mathrm{Mo}$ & 290 & 90 & 100 & 17 \\
\hline $\mathrm{NL}-8$ & $9.4 \mathrm{~V}-9.9 \mathrm{Zr}$ & 270 & 560 & 420 & 9 \\
\hline NL -9 & $11.4 \mathrm{~V}-5.7 \mathrm{Zr}$ & 1780 & 220 & 250 & 19 \\
\hline $\mathrm{NL}-10$ & $9.6 \mathrm{Ti}-3.3 \mathrm{Cr}$ & 226 & 60 & 160 & 2 \\
\hline NL-11 & $7.6 \mathrm{~V}$ & 240 & 160 & 160 & 7 \\
\hline NL -12 & $8.7 \mathrm{~V}-0.26 \mathrm{~N}$ & 280 & 400 & 200 & 21 \\
\hline NL-13 & $7.3 \mathrm{~V}-2.4 \mathrm{Ti}$ & 300 & 170 & 110 & 18 \\
\hline NL-14 & $7.6 \mathrm{~V}-2.3 \mathrm{Mo}$ & 244 & 150 & 130 & 10 \\
\hline
\end{tabular}

(a) All materials analyzed after fabrication and vacuum annealing.

(b) Fabricated from electron-beam-melted stock (without remelting) by cold rolling. 
Radiographs made for each of the double consumable-electrode-melted alloy ingots indicated that each was sound and free of porosity. After surface cleanup by light machining, the first three alloy ingots (NL-1, NL-2, and NL-3 in Table 4) were simply inserted in 1-5/8-in. -ID by 3-in. -OD stainless steel cans which were closed by welding in end plugs under a partial pressure of helium. For these as for all packrolled materials, the chromic oxide-water glass slurry was used to prevent bonding of the alloys to the stainless steel.

The canned ingots were then forged in air at $1950 \mathrm{~F}$ to 1 -in. -thick billets. X-ray inspection of the canned billets showed the niobium- 45.9 a/o zirconium alloy was badly cracked while the niobium-12.6 a/o vanadium and niobium-7. 2 a/o molybdenum alloy billets showed only minor edge cracking. All three billets were then rolled to 1/8-in. thick sheet at $1800 \mathrm{~F}$.

On attempted stripping of the alloys from the stainless steel, it was found that the niobium-45. 9 a/o zirconium alloy was too badly fragmented to be salvageable. Visible evidences of wetting of the stainless steel indicated that liquation had occurred in the contact areas between this alloy and the steel. This was apparently caused by the formation of a low-melting eutectic due to interdiffusion of the zirconium (from the alloy), chromium, iron, and nickel (from the stainless steel) at $1950 \mathrm{~F}$. The other two alloy sheets were readily removed from the stainless and had moderately rough surfaces with edge cracking that was no more severe than that observed on these same alloy ingots after forging.

In an attempt to expedite fabrication, forging of the next three alloy ingots (NI.-4, -5 , and -6 , in Table 4) was attempted in air at $2200 \mathrm{~F}$. However, when each of the three ingots developed radial cracks during the initial upsetting operations, forging was stopped and abandoned in the fabrication process for the large, arc-melted alloy ingots. Instead, the practice of direct hot rolling stainless steel-clad slabs cut from the ingots was adopted, as described earlier in this report.

As shown in Table 4, sheet of good to very good quality was obtained from all of the ingots rolled using this technique excepting only the niobium- 45 a/o zirconium3. I a/o vanadium alloy which fragmented severely.

As a check on the homogeneity of the alloys, samples from the ends and centers of two 30-in. -long alloy strips were analyzed for major metallic additions with the following results:

Alloy Content (Balance Niobium), a/o

\begin{tabular}{|c|c|c|c|c|c|}
\hline \multirow[b]{2}{*}{ Alloy } & \multirow[b]{2}{*}{ Charged } & \multicolumn{4}{|c|}{ Analyzed } \\
\hline & & End A & Center & End B & Average \\
\hline$N L-2$ & $13.1 \mathrm{~V}$ & $12.65 \mathrm{~V}$ & $12.81 \mathrm{~V}$ & 12. $28 \mathrm{~V}$ & $12.58 \mathrm{~V}$ \\
\hline NL- 3 & $7.5 \mathrm{Mo}$ & 7. $22 \mathrm{Mo}$ & $7.02 \mathrm{Mo}$ & 7. $30 \mathrm{Mo}$ & 7. $18 \mathrm{Mo}$ \\
\hline
\end{tabular}

These results indicated good alloy homogeneity was obtained in melting and, on this basis, single analyses only were obtained on the balance of the fabricated alloy sheets. An exception was made in the case of the nominal 9.9 a/o titanium- 6.7 a/o chromium alloy sheet (Alloy NL-10) for which two separate samples were analyzed for chromium content. Here, due to variable losses in melting, the chromium content ranged from 0.44 a/o at one end of the sheet to 6.3 a/o at the other. 
Analyses for interstitial contaminants were obtained on each of the annealed alloy sheets with the results shown in Table 5. Marked increases in interstitial content were observed for several alloys, especially those containing vanadium. It appears possible that the higher oxygen contents of Alloys NL-2 and NL-3 resulted from heating these ingots to a higher temperature $(1950 \mathrm{~F}$ ) during fabrication than the other ingots (1800 F max). On the other hand, the higher-than-average levels of carbon, nitrogen, and oxygen in the vanadium-containing alloys suggest that appreciable amounts of these contaminants were contained in the vanadium. The very high oxygen content (1780 ppm) of the niobium-11.4 a/o vanadium-5. 7 a/o zirconium alloy shows that significant oxygen contamination, from an unknown source, also occurred in this alloy.

\section{Metallography}

The structures of most of the binary alloys and some of the ternary alloys were examined in the vacuum-annealed condition. As indicated in Table 6, most of these alloys consisted of a single-phase solid-solution structure based on the niobium. Figures $1 \mathrm{l}$ and $\mathrm{lb}$ show representative equiaxed structures observed for the base material and the alloys.

As noted in Table 6 , binary alloys containing 10 a/o iron or 10.5 through 45.7 a/o zirconium contained two phases. Similarly, each of the ternary alloys containing zirconium also contained varying amounts of apparently the same zirconium-rich second phase observed in the binary zirconium alloys. In the 2.5 a/o vanadium- 2.5 a/o zirconium, this phase occurred in the form of widely spaced, randomly distributed particles as shown in Figure lc. The alloys with 10.5 to 45.7 a/o zirconium contained appreciably more of this phase which was distributed both inter- and intragranularly as a very fine dispersion. Similar structures were found in the 11.4 a/o vanadium-5.7 a/o zirconium (Figure $1 d$ ) and 9.4 a/o vanadium- 9.9 a/o zirconium ternary alloys. Lesser amounts of apparently the same phase were observed in the annealed 46.8 a/o zirconium5.1 a/o titanium alloy as shown in Figure 1 e.

One metallographic sample of the segregated 9.6 a/o titanium- 3.3 a/o chromium alloy (illustrated in Figure lf) showed traces of a second phase at the grain boundaries. Three other titanium-chromium alloys of higher titanium:chromium ratios, prepared as smaller ingots, were all single phase. Accordingly, the extraneous phase in the 9.6 a/o titanium-3. 3 a/o chromium alloy was tentatively identified as a chromium-rich phase resulting from chromium segregation and is probably based on the $\mathrm{NbCr}_{2}$ compound.

\section{Corrosion Testing}

Corrosion tests were conducted under degassed conditions in static high-purity 600 and $680 \mathrm{~F}$ water and in $750 \mathrm{~F}, 1500$-psi steam. Corrosion behavior was established by noting changes in weight and surface appearance for successive exposure periods. Metallographic examinations and hydrogen assays also were conducted on selected specimens. 
TABLE 6. SUMMARIZED DESCRIPTION OF METALLOGRAPHIC STRUCTURES OBSERVED IN ANNEALED NIOBIUM-BASE ALLOYS

\begin{tabular}{|c|c|}
\hline \multicolumn{2}{|c|}{ Composition Range (Balance Niobium) $)^{(\mathrm{a})}, \mathrm{a} / \mathrm{o}$} \\
\hline Single-Phase Alloy Structures & Two-Phase Alloy Structures \\
\hline \multicolumn{2}{|c|}{ Binary Alloys } \\
\hline $0-33.8 \mathrm{Ti}$ & -. \\
\hline $0-24.2 \mathrm{~V}$ & -- \\
\hline $0-7.4 \mathrm{Mo}$ & - \\
\hline $0-4.9 \mathrm{Fe}$ & $10 \mathrm{Fe}^{(\mathrm{b})}$ \\
\hline $0-4.7 \mathrm{~W}$ & -- \\
\hline.- & $10.5-45.7 \mathrm{Zr}$ \\
\hline \multicolumn{2}{|c|}{ Ternary Alloys } \\
\hline $12 \mathrm{Ti}-0.5 \mathrm{Cr}$ & - \\
\hline $20.2 \mathrm{Ti}-2.1 \mathrm{Cr}$ & -- \\
\hline $28.2 \mathrm{Ti}-6.1 \mathrm{Cr}$ & -- \\
\hline $11.2 \mathrm{Ti}-3.2 \mathrm{Mo}$ & -- \\
\hline $12 \mathrm{Ti}-4.2 \mathrm{Mo}$ & -- \\
\hline $17.4 \mathrm{Ti}-6.2 \mathrm{Mo}$ & -- \\
\hline $18.8 \mathrm{Ti}-8.7 \mathrm{Mo}$ & -- \\
\hline $10.4 \mathrm{Ti}-5 \mathrm{~V}$ & -- \\
\hline $16.1 \mathrm{Ti}-8.4 \mathrm{~V}$ & -- \\
\hline $22.6 \mathrm{Ti}-11 \mathrm{~V}$ & -- \\
\hline- & $2.5 \mathrm{~V}-2.5 \mathrm{Zr}^{(\mathrm{b})}$ \\
\hline- & $9.4 \mathrm{~V}-9.9 \mathrm{Zr}$ \\
\hline-- & $11.4 \mathrm{~V}-5.7 \mathrm{Zr}$ \\
\hline-- & $46.8 \mathrm{Zr}-5.1 \mathrm{Ti}$ \\
\hline
\end{tabular}

(a) All vacuum annealed $1 \mathrm{hr}$ at $2730 \mathrm{~F}$ and furnace cooled unless otherwise indicated.

(b) Vacuum annealed $1 \mathrm{hr}$ at $2190 \mathrm{~F}$ and furnace cooled. 


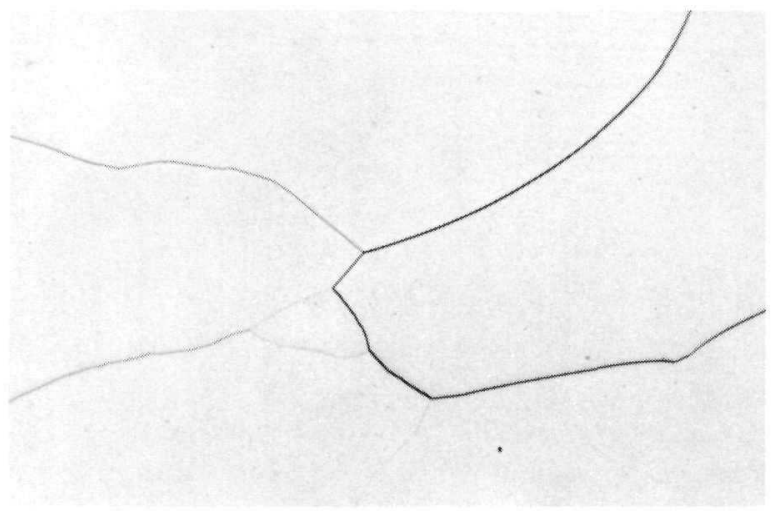

$100 \mathrm{X}$

N57528

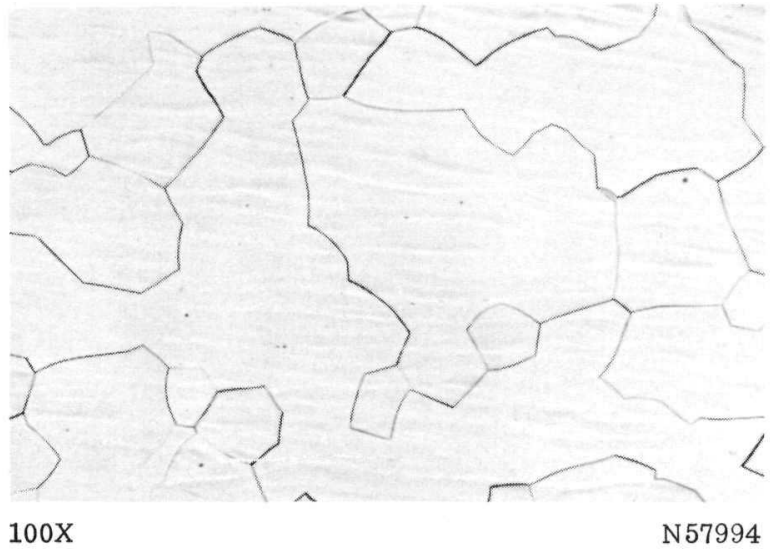

b. Niobium-18. 8 a/o Titanium-8. 7 a/o Molybdenum

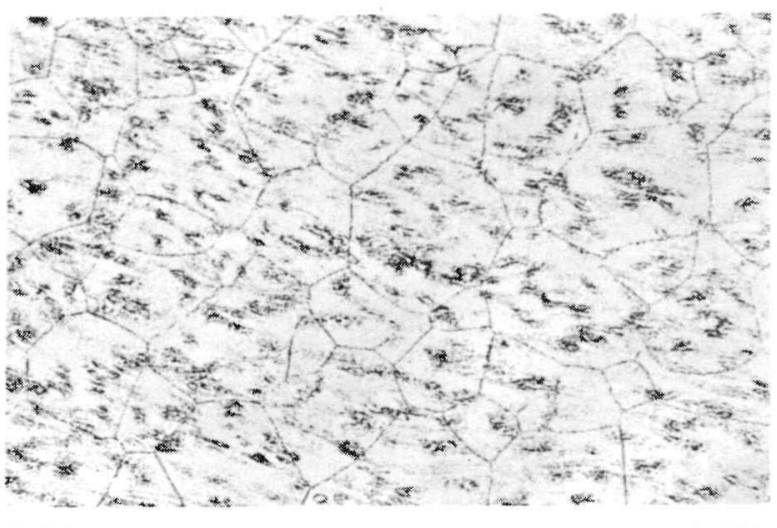

$100 \mathrm{X}$

N61366

d. Niobium-11.4 a/o Vanadium-5.7 a/o Zirconium

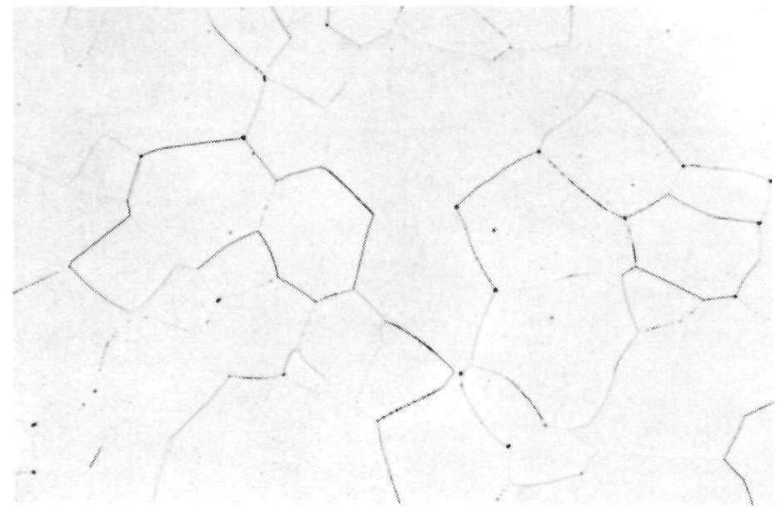

$100 \mathrm{X}$
N61367
$100 \mathrm{X}$

N57997

e. Niobium-46. 8 a/o Zirconium-5. 1 a/o Titanium

f. Niobium-9.6 a/o Titanium-3. 3 a/o Chromium 
Appearance of Corroded Samples

The corrosion film on unalloyed niobium was dark gray to black in all test conditions. It was adherent during initial exposures, but eventually began to spall. Of the alloys studied, those containing more than 40 to 45 a/o zirconium, a ternary with 28.2 a/o titanium-6. 1 a/o chromium and a ternary with 10.9 a/o zirconium-5. 1 a/o iron exhibited adherent tarnish films throughout the course of the tests (196 days in $680 \mathrm{~F}$ water). The alloys which contained zirconium were covered with an adherent shiny black film while the titanium-chromium alloy possessed an iridescent tarnish during the entire exposure. A number of alloys exhibited tarnish films which were replaced by a dark-gray or brown film upon continued exposure. Included among these were binary alloys containing 25 to 35 a/o zirconium, 7.5 a/o molybdenum, 10 to 25 a/o vanadium, 20 to 35 a/o titanium, and ternaries containing at least one of the above elements in the composition range listed. All other alloy specimens were covered with dark-gray or brown films after the initial exposure.

\section{Identification of Surface Oxides}

Attempts were made using X-ray diffraction techniques to identify the species of oxides which occurred on the surfaces of several corroded alloy samples. The results are summarized in Table 7. The low-temperature $\mathrm{T}$-type modification (4) of $\mathrm{Nb}_{2} \mathrm{O}_{5}$ was observed as the major constituent in the oxide scales of unalloyed niobium and the 4.7 a/o tungsten alloy. On the other hand, new oxides of $6 \mathrm{ZrO}_{2} \cdot \mathrm{Nb}_{2} \mathrm{O}_{5}$ and $\mathrm{TiO}_{2}$ rutile were found in the 45.7 aio zirconium and 28.2 a/o titanium-6. 1 a/o chromium alloy scales, respectively.

TABLE 7. IDENTIFICATION OF SURF ACE OXIDES BY X-RAY DFFRACTION

\begin{tabular}{|c|c|c|c|}
\hline Alloy & $\begin{array}{c}\text { Alloy Content } \\
\text { (Balance Niobium), } \\
\text { a/o }\end{array}$ & $\begin{array}{c}\text { Corrosion Time } \\
\text { in } 680 \mathrm{~F} \text { Water, } \\
\text { days }\end{array}$ & Phases in Scale \\
\hline-- & $100 \mathrm{Nb}$ & 28 & $\mathrm{~T}-\mathrm{Nb}_{2} \mathrm{O}_{5}{ }^{(\mathrm{a})}$ \\
\hline 149 & $10.7 \mathrm{~V}$ & 196 & Unidentufiable phase plus trace of $\mathrm{NbO}$ \\
\hline 151 & $24.2 \mathrm{~V}$ & 196 & Unidentifiable \\
\hline 164 & $4.7 \mathrm{~W}$ & 196 & $\mathrm{~T}-\mathrm{Nb}_{2} \mathrm{O}_{5}$ \\
\hline 141 & $45.7 \mathrm{Zr}$ & 42 & $6 \mathrm{ZrO}_{2} \cdot \mathrm{Nb}_{2} \mathrm{O}_{5}$ \\
\hline 144 & $24.3 \mathrm{Ti}$ & 196 & $\begin{array}{l}\text { Two unidentifiable phases, one of which } \\
\text { is similar to niobium- } 24.2 \text { vanadium } \\
\text { phase }\end{array}$ \\
\hline 177 & $28.2 \mathrm{Ti}-6.1 \mathrm{Cr}$ & $\begin{array}{r}42 \\
196\end{array}$ & $\begin{array}{l}\text { Unidentifiable } \\
\mathrm{TiO}_{2}^{(\mathrm{b})}\end{array}$ \\
\hline
\end{tabular}

(a) A phase believed to be hydrogen-distorted niobium was also noted in scrapings from sample surface.

(b) Identification is tentative. 
Corrosion Rates

Commercial-Purity Niobium-Base Alloys. Corrosion tests of a screening nature were conducted in $680 \mathrm{~F}$ water on the commercial-purity niobium-base alloys listed in Table 8. Where sufficient material was available, specimens from the same alloys were also exposed to $750 \mathrm{~F}, 1500-$ psi steam.

Weight-change data obtained at the intermediate exposure periods were somewhat erratic. Plotted curves exhibited a "wavy" appearance which suggested occasional loss of corrosion product. Contributing factors were believed to be: (1) slight powdering of the gray or brown corrosion films, (2) small specimen size, and (3) exposure of occasional defects which had been smeared over and not removed during specimen preparation. As a result of this erratic behavior, weight change-versus-time plots were not obtained, although the data seemed to follow a parabolic rate law for several of the alloys. The cumulative weight-change data after 196 days' exposure for the alloys investigated are included in Table 8 . The unalloyed niobium was completely oxidized after 42 days' exposure, while the 9.6 a/o tungsten alloy cracked within 7 days. Alloys containing 1.1 and 4.7 a/o tungsten or 2.45 and 5.2 a/o molybdenum were losing weight. All other alloy specimens gained weight. The most resistant alloy appeared to be the 45.7 a/o zirconium binary and the 28.2 a/o titanium-6. 1 a/o chromium ternary which exhibited adherent shiny black and iridescent tarnish films, respectively.

Corrosion results for the commercial-purity niobium-base alloys exposed to $750 \mathrm{~F}$ steam also are presented in Table 8. The accelerated nature of attack was quite pronounced on the less-corrosion-resistant alloys. The unalloyed niobium was completely oxidized within 28 days' exposure, while the 2.45 a/o molybdenum and 4.9 a/o iron alloys were completely oxidized at 98 days' exposure. The remaining alloys have survived 210 days' exposure, although weight losses are very high on the 10.5 a/o zirconium, 1.1 a/o tungsten, and 5.2 a/o molybdenum alloys running 3, 970, 6, 420, and $18,450 \mathrm{mg}$ per $\mathrm{dm}^{2}$, respectively. The $4.4 \mathrm{a} / \mathrm{o}$ vanadium alloy also is losing weight at $2400 \mathrm{mg}$ per $\mathrm{dm}^{2}$, while the 6.6 and 8.9 vanadium and the 9.4 a/o titanium alloys possess weight gains in the range of 120 to $125 \mathrm{mg}$ per $\mathrm{dm}^{2}$. The latter were about double those observed for replicate specimens after 196 days' exposure to $680 \mathrm{~F}$ water.

High-Purity Niobium-Base Alloys. Corrosion tests were conducted on high-purity niobium-base alloys taken from two sizes of arc melts: (1) consumable-electrode melts weighing several pounds and (2) rocking-hearth arc melts weighing $50 \mathrm{~g}$. The former were used for extensive mechanical-property evaluation, while the latter were used as screening alloys in the search for improved properties.

Consumable-Electrode Arc Melts. The quantity of material available from the consumable-electrode melts was sufficient to conduct corrosion studies at all three test temperatures. The results after exposures of up to 280 days are summarized in Table 9. It is apparent from comparing the data in Tables 8 and 9 that the high-purity unalloyed niobium exhibits a much longer corrosion life than does the commercial-purity stock. However, in the initial stages of corrosion there is little difference between the two as illustrated in Figure 2. 
TABLE 8. SUMMARY OF CORROSION RESULTS FOR COMMERCIAL-PURITY NIOBIUM-BASE ALLOYS EXPOSED TO WATER AND STEAM

\begin{tabular}{|c|c|c|c|c|c|c|c|c|}
\hline \multirow[b]{2}{*}{ Alloy } & \multirow[b]{2}{*}{$\begin{array}{c}\text { Alloy Content } \\
\text { (Balance Niobium), } \\
a / 0\end{array}$} & \multirow{2}{*}{$\begin{array}{l}\text { Thermal- } \\
\text { Neutron- } \\
\text { Absorption } \\
\text { Cross Section, } \\
\text { barns per atom }\end{array}$} & \multicolumn{2}{|c|}{$600 \mathrm{~F}$ Water } & \multicolumn{2}{|c|}{$680 \mathrm{~F} \mathrm{Water}$} & \multicolumn{2}{|c|}{$750 \mathrm{~F}$ Steam } \\
\hline & & & $\begin{array}{l}\text { Exposure } \\
\text { Time, } \\
\text { days }\end{array}$ & $\begin{array}{l}\text { Total Weight } \\
\text { Change, } \\
\text { mg per } \mathrm{dm}^{2}\end{array}$ & $\begin{array}{l}\text { Exposure } \\
\text { Time, } \\
\text { days }(a)\end{array}$ & $\begin{array}{c}\text { Total Weight } \\
\text { Ghange, } \\
\text { mg per } \mathrm{dm}^{2}\end{array}$ & $\begin{array}{l}\text { Exposure } \\
\text { Time, } \\
\text { days }\end{array}$ & $\begin{array}{l}\text { Total Weight } \\
\text { Change, } \\
\text { mg per dm }\end{array}$ \\
\hline -- & $100 \mathrm{Nb}$ & 1.15 & 196 & -1860 & 42 & Disintegrated & $28^{(a)}$ & Disintegrated \\
\hline 138 & $10.5 \mathrm{Zr}$ & 1.05 & -- & -- & 196 & 67 & 210 & $-3,970$ \\
\hline 139 & $26.1 \mathrm{Zr}$ & 0.90 & -- & -- & 196 & 7 & -- & -- \\
\hline 140 & $35.7 \mathrm{Zr}$ & 0.81 & - & - & 196 & 66 & - & - \\
\hline 141 & $45.7 \mathrm{Zr}$ & 0.71 & - & - & 196 & 55 & -- & - \\
\hline 163 & $1.1 \mathrm{~W}$ & 1.3 & -- & -- & 196 & -260 & 210 & $-6,420$ \\
\hline 164 & $4.7 \mathrm{~W}$ & 2.0 & -- & - & 196 & $-2,930$ & - & -- \\
\hline 165 & $9.6 \mathrm{~W}$ & 2.8 & - & -- & 7 & Cracked & - & -- \\
\hline 152 & 2. $45 \mathrm{Mo}$ & 1. 18 & -- & - & 196 & -710 & $98(a)$ & Disintegrated \\
\hline 153 & $5.2 \mathrm{Mo}$ & 1. 21 & -- & -- & 196 & -130 & 210 & $-18,450$ \\
\hline 154 & 7. $4 \mathrm{Mo}$ & 1.26 & -- & $\cdots$ & 196 & 62 & -- & -- \\
\hline 150 & $4.4 \mathrm{~V}$ & 1. 30 & -- & - & 196 & 42 & 210 & $-2,400$ \\
\hline 147 & $6.6 \mathrm{~V}$ & 1.38 & -- & $\cdots$ & 196 & 73 & 210 & 127 \\
\hline 148 & $8.9 \mathrm{~V}$ & 1. 48 & -- & $\cdots$ & 196 & 59 & 210 & 118 \\
\hline 149 & $10.7 \mathrm{~V}$ & 1. 54 & -- & -- & 196 & 78 & -- & -- \\
\hline 158 & $13.7 \mathrm{~V}$ & 1. 65 & - & -- & 196 & 50 & -. & -- \\
\hline 151 & $24.2 \mathrm{~V}$ & 2.06 & - & -- & 196 & 0 & -- & - \\
\hline 169 & 4. $9 \mathrm{Fe}$ & 1.22 & - & -- & 196 & 10 & $98^{(a)}$ & Disintegrated \\
\hline 142 & $9.4 \mathrm{~T}_{1}$ & 1. 58 & -- & -- & 196 & 65 & 210 & 119 \\
\hline 143 & $18.8 \mathrm{~T} 1$ & 2.02 & -- & $\cdots$ & 196 & 48 & - & -- \\
\hline 144 & $24.3 \mathrm{TI}$ & 2.26 & -- & - & 196 & 52 & - & -- \\
\hline 145 & $30.5 \mathrm{TI}$ & 2.58 & -- & -- & 196 & 40 & - & - \\
\hline 146 & $33.8 \mathrm{~T} 1$ & 2.72 & -- & -- & 196 & 33 & -- & - \\
\hline 175 & $12.0 \mathrm{~T} 1-0.5 \mathrm{Cr}$ & 1. 72 & - & - & 196 & 66 & -- & - \\
\hline 176 & $20.2 \mathrm{~T}_{1}-2.1 \mathrm{Cr}$ & 2.12 & - & -- & 196 & 39 & - & - \\
\hline 177 & $28.2 \mathrm{~T} 1-6.1 \mathrm{Cr}$ & 2.56 & - & -- & 196 & 20 & - & - \\
\hline 172 & $12 \mathrm{~T}_{1}-4.2 \mathrm{Mo}$ & 1. 78 & -- & -- & 196 & 64 & -- & -- \\
\hline 173 & 17. 4 T1-6. 2 Mo & 2.06 & - & -- & 196 & 54 & - & -- \\
\hline 174 & $23.1 \mathrm{~T} 1-7.8 \mathrm{Mo}$ & 2.35 & -- & - & 196 & 45 & - & -- \\
\hline 178 & $10.4 \mathrm{~T}_{1}-5.0 \mathrm{~V}$ & 1. 57 & -- & -- & 196 & 56 & -- & -- \\
\hline 179 & $16.1 \mathrm{~T}_{1}-8.4 \mathrm{~V}$ & 1. 80 & - & -- & 196 & 40 & -- & - \\
\hline 180 & $22.6 \mathrm{Tl}-11.0 \mathrm{~V}$ & 2.05 & -- & -- & 196 & 48 & - & - \\
\hline- & Zircaloy -2 & 0.19 & 200 & $22^{(b)}$ & 200 & $66(\mathrm{~b})$ & 200 & $243^{(b)}$ \\
\hline
\end{tabular}

(a) Specimens off test.

(b) Reference (5). 
TABLE 9. SUMMARY OF CORROSION RESULTS FOR CONSUMABLE-ELECTRODE -MELTED HIGH-PURITY NIOBIUM-BASE ALLOYS EXPOSED TO WATER AND STEAM

\begin{tabular}{|c|c|c|c|c|c|c|c|}
\hline \multirow{2}{*}{$\begin{array}{c}\text { Alloy } \\
\text { Addition } \\
\text { (Balance Niobium) } \\
\text { a/o }\end{array}$} & \multirow{2}{*}{$\begin{array}{l}\text { Thermal- } \\
\text { Neutron- } \\
\text { Absorption } \\
\text { Cross Section, } \\
\text { barns per atom }\end{array}$} & \multicolumn{2}{|c|}{$600 \mathrm{~F}$ Water } & \multicolumn{2}{|c|}{$680 \mathrm{~F}$ Water } & \multicolumn{2}{|c|}{750 F Steam } \\
\hline & & $\begin{array}{l}\text { Exposure } \\
\text { Time, } \\
\text { days }\end{array}$ & $\begin{array}{l}\text { Total Weight } \\
\text { Change, } \\
\text { mg per } \mathrm{dm}^{2}\end{array}$ & $\begin{array}{l}\text { Exposure } \\
\text { Time, } \\
\text { days }\end{array}$ & $\begin{array}{l}\text { Total Weight } \\
\text { Change, } \\
\text { mg per } \mathrm{dm}^{2}\end{array}$ & $\begin{array}{l}\text { Exposure } \\
\text { Time, } \\
\text { days }\end{array}$ & $\begin{array}{l}\text { Total Weight } \\
\text { Change, } \\
\text { mg per dm }{ }^{2}\end{array}$ \\
\hline $100 \mathrm{Nb}(\mathrm{b})$ & 1. 15 & 280 & 76 & 280 & -722 & $224^{(a)}$ & -5400 \\
\hline $7.2 \mathrm{Mo}$ & 1.25 & 280 & 73 & $224^{(a)}$ & Cracked & $70^{(\mathrm{a})}$ & Cracked \\
\hline $12.6 \mathrm{~V}$ & 1.61 & 280 & 40 & 280 & 72 & 280 & 76 \\
\hline $46.8 \mathrm{Zr}-5.1 \mathrm{TI}$ & 0.92 & 280 & 24 & 280 & 103 & 280 & 254 \\
\hline $11.2 \mathrm{Tl}-3.2 \mathrm{Mo}$ & 1. 72 & 280 & 36 & 280 & 66 & 280 & $36^{(c)}$ \\
\hline $18.8 \mathrm{~T} 1-8.7 \mathrm{Mo}$ & 2.15 & 280 & 22 & 280 & 66 & 280 & $53^{(c)}$ \\
\hline $11.4 \mathrm{~V}-5.7 \mathrm{Zr}$ & 1. 50 & 196 & 6 & 196 & 43 & 196 & -237 \\
\hline $9.4 \mathrm{~V}-9.9 \mathrm{Zr}$ & 1.39 & 196 & $14^{(c)}$ & 196 & $23^{(c)}$ & 196 & -682 \\
\hline $9.6 \mathrm{~T} 1-3.3 \mathrm{Cr}$ & 1.75 & 196 & -4 & 196 & 50 & 196 & -553 \\
\hline Zircaloy -2 & 0.19 & 200 & $22^{(\mathrm{d})}$ & 200 & $66^{(d)}$ & 200 & $243(d)$ \\
\hline
\end{tabular}
(a) Specimens off test.
(b) Portion of as-recelved electron-beam-melted ingot.
(c) Specimens are losing weight.
(d) Reference (5). 


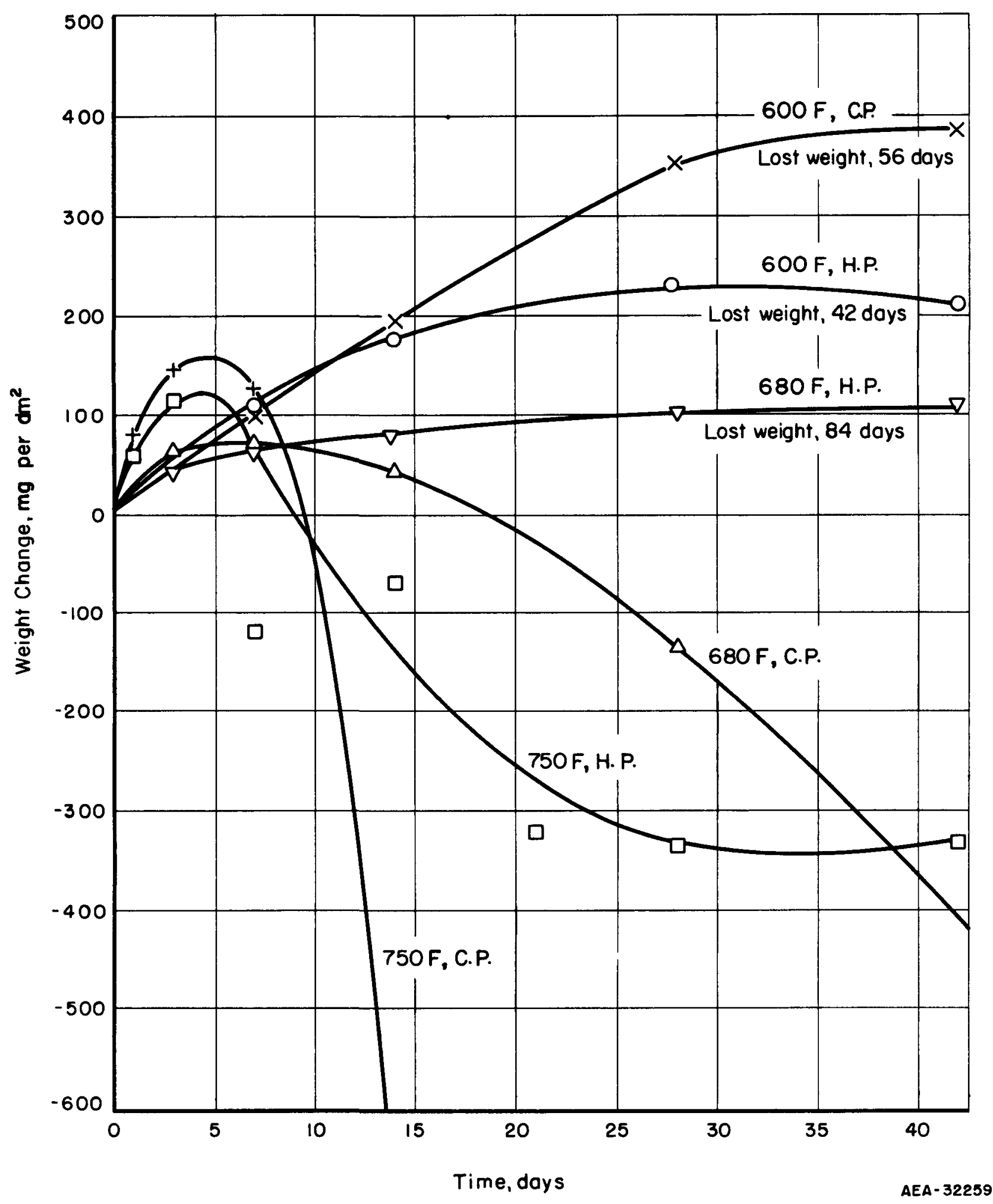

FIGURE 2. WEIGHT CHANGES FOR COMMERCIAL PURITY (C.P.) AND HIGH-F'URITY (H.P.) NIOBIUM IN 600 AND $680 \mathrm{~F}$ WATER AND IN $750 \mathrm{~F}$ STEAM 
Weight-change data for the consumable-electrode-melted alloys were quite consistent. Smooth curves could be drawn through the cumulative weight-change data. With one or two exceptions, all alloys gained weight. Typical weight change-time curves for the alloys are presented in Figures 3, 4, and 5. It is obvious from the plots that unalloyed niobium is not so resistant to high-temperature water as several of its alloys. The corrosion curve for Zircaloy-2 also is included in these plots for comparison purposes. Several of the alloys, notably 12.6 a/o vanadium, 11.2 a/o titanium$3.2 \mathrm{a} / \mathrm{o}$ molybdenum, and $18.8 \mathrm{a} / 0$ titanium-8. $7 \mathrm{a} / \mathrm{o}$ molybdenum, exhibit weight changes which are comparable with those for Zircaloy- 2 .

The corrosion reaction kinetics can be expressed by the equation:

$$
\mathrm{W}=\mathrm{Kt} \mathrm{t}^{\mathrm{n}} \text {, }
$$

where

$$
\begin{aligned}
\mathrm{W}= & \text { total weight gain, } \mathrm{mg} \text { per } \mathrm{dm}^{2} \\
\mathrm{~K}= & \begin{array}{l}
1 \text {-day intercept of a log-log plot of weight gain versus time } \\
\text { (also in mg per } \mathrm{dm}^{2} \text { ) }
\end{array} \\
\mathrm{t}= & \text { exposure time, days } \\
\mathrm{n}= & \text { slope of the resulting straight line on the log-log plot. }
\end{aligned}
$$

The values obtained for $K$ and $n$ for all of the consumable-electrode-melted alloys are presented in Table 10. The value of $\mathrm{n}$ for most of the alloys approached 0.5 indicating that the corrosion rate appeared to follow the parabolic rate law. The 12.6 a/o vanadium alloy appeared to be the most corrosion resistant of the group studied. It has exhibited relatively low values for $K$ and $n$ and still possesses an adherent film after 280 days' exposure at all three test temperatures. The 46.8 a/o zirconium-5. 1 a/o titanium alloy and the 18.8 a/o titanium-8. 7 a/o molybdenum alloy also appears to possess good corrosion resistance.

Rocking-Hearth Arc Melts. The screening alloys prepared in the rocking-hearth arc furnace were tested in $680 \mathrm{~F}$ water only. Included in the study were binary alloys containing cerium, chromium, iron, nickel, palladium, titanium, yttrium, or zirconium and ternary alloys containing vanadium or zirconium plus one of the following: aluminum, chromium, iron, molybdenum, nickel, titanium, vanadium, or zirconium. Total weight changes obtained after exposure times ranging from 56 to 224 days are presented in Table 11 . The values of $\mathrm{K}$ and $\mathrm{n}$ describing the reaction-rate kinetics for the se alloys [see Equation (1)] are summarized in Table 12.

At the exposure times indicated in Table 11 all alloy specimens were gaining weight at a uniform rate except the following:

Unalloyed niobium

1 to 10 a/o zirconium

3.2 a/o titanium

$<0.02$ to 0.5 a/o chromium

$<0.08$ to 10 a/o iron
1 a/o cerium

1 to 5 a/o yttrium

2.5 a/o vanadium-2. 5 a/o nickel or zirconium 10 a/o zirconium-5 a/o molybdenum 


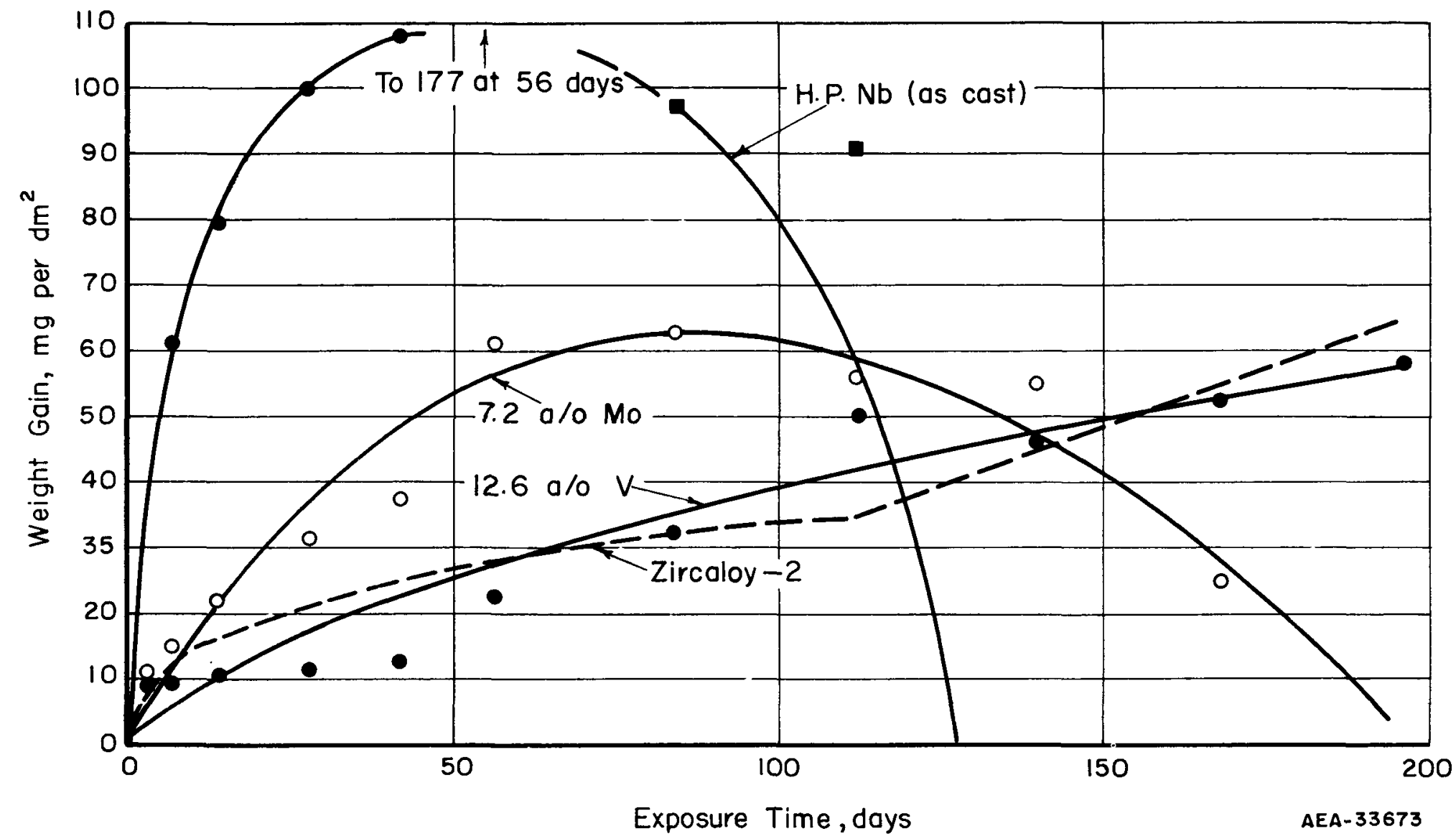

FIGURE 3. CORROSION RESULTS FOR HIGH-PURITY AND COMMERCIAL-PURITY NIOBIUM-BASE ALLOYS EXPOSED TO $680 \mathrm{~F}$ WATER 


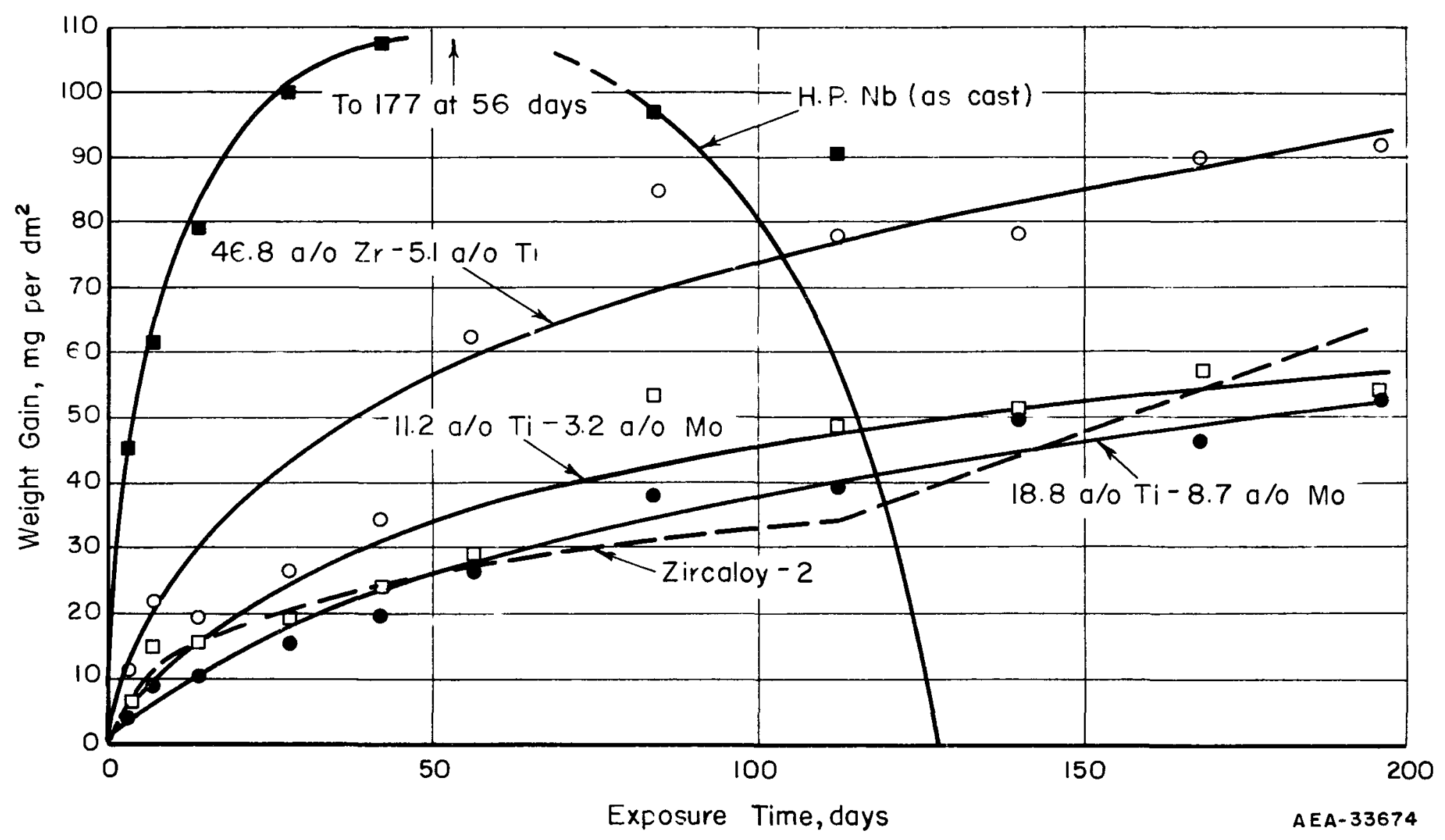

FIGURE 4. CORROSION RESULTS FOR HIGH-PURITY NIOBIUM-BASE A」IIOYS EXPOSED TO 680 F WATER 


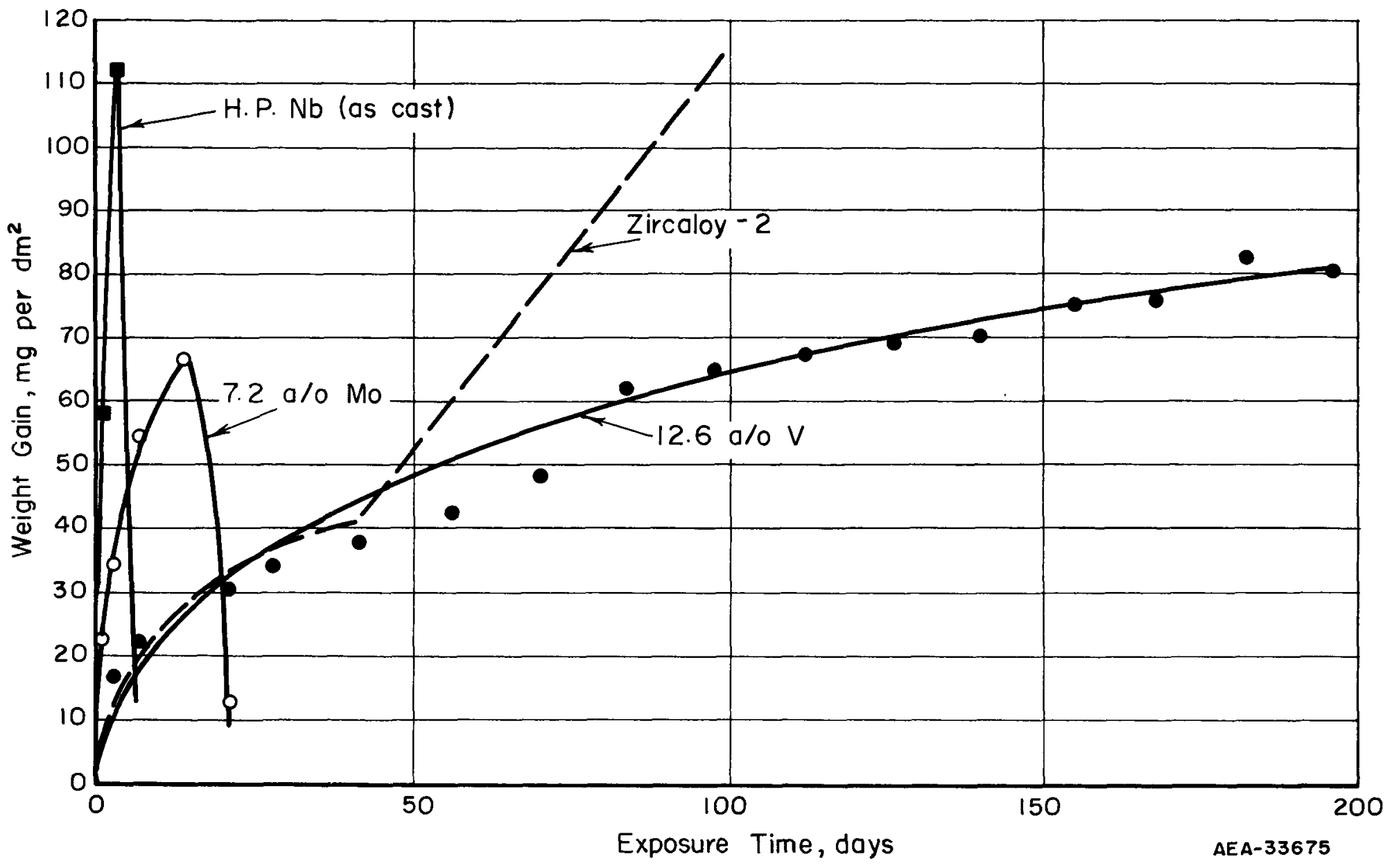

FIGURE 5. CORROSION RESULTS FOR HIGH-PURITY NIOBIUM-BASE ALLOYS EXPOSED TO $750 \mathrm{~F}, 1500-$ PSI STEAM 
TABLE 10. RATE CONSTANTS FOR THE CORROSION OF CONSUMABLE-ELECTRODE-MELTED HIGH-PURITY NIOBIUM-BASE ALLOYS IN HIGH-TEMPERATURE WATER AND STEAM

\begin{tabular}{|c|c|c|c|c|c|c|c|c|c|}
\hline \multirow[b]{2}{*}{$\begin{array}{c}\text { Alloy Addition } \\
\text { (Balance Niobium), } \\
\text { a/o }\end{array}$} & \multicolumn{3}{|c|}{$600 \mathrm{~F}$ Water } & \multicolumn{3}{|c|}{$680 \mathrm{~F}$ Water } & \multicolumn{3}{|c|}{$750 \mathrm{~F}, 1500$-PSI Steam } \\
\hline & $\begin{array}{c}\text { Exposure } \\
\text { Time, } \\
\text { days }\end{array}$ & $\begin{array}{l}\mathrm{K}^{(\mathrm{a})}, \\
\text { mg per dm², } \\
1 \text { Day }\end{array}$ & $\begin{array}{c}n, \\
\text { Dimensionless }\end{array}$ & $\begin{array}{c}\text { Exposure } \\
\text { Time, } \\
\text { days } \\
\end{array}$ & $\begin{array}{c}\mathrm{K}(\mathrm{a}) \\
\text { mg per dm } \\
1 \text { Day } \\
\end{array}$ & $\begin{array}{c}\mathrm{n}, \\
\text { Dimensionless }\end{array}$ & $\begin{array}{c}\text { Exposure } \\
\text { Time, } \\
\text { days }\end{array}$ & $\begin{array}{l}\mathrm{K}^{(\mathrm{a})}, \\
\text { mg per dm }{ }^{2}, \\
1 \text { Day }\end{array}$ & $\begin{array}{c}\mathrm{n}, \\
\text { Dimensionless }\end{array}$ \\
\hline $100 \mathrm{Nb}$ & $28(\mathrm{~b})$ & 3.0 & 0.62 & $42^{(b)}$ & 3.1 & 0.34 & $3^{(b)}$ & 58 & 0.60 \\
\hline $12.6 \mathrm{~V}$ & 280 & 1.6 & 0.58 & 280 & 2.5 & 0.63 & 280 & 12 & 0.36 \\
\hline $7.2 \mathrm{Mo}$ & 280 & 1.0 & 0.79 & $112^{(b)}$ & 6.6 & 0.44 & $14^{(b)}$ & 22 & 0.46 \\
\hline $46.8 \mathrm{Z} \Gamma-5.06 \mathrm{Ti}$ & 280 & 1.3 & 0.57 & 280 & 6.5 & 0.50 & 266 & 13 & 0.56 \\
\hline 11. $2 \mathrm{Ti}-3.2 \mathrm{Mo}$ & 280 & 2.5 & 0.54 & 280 & .3 .4 & 0.55 & $154^{(b)}$ & 10 & 0.43 \\
\hline $18.8 \mathrm{Ti}-8.7 \mathrm{Mo}$ & 280 & 2.0 & 0.47 & 280 & 2.2 & 0.60 & $196^{(b)}$ & 7.6 & 0.40 \\
\hline $11.4 \mathrm{~V}-5.7 \mathrm{Zr}$ & $84^{(b)}$ & 2.5 & 0.40 & 196 & 13 & 0.22 & $28^{(b)}$ & 20 & 0.11 \\
\hline $9.4 \mathrm{~V}-9.9 \mathrm{Zr}$ & $84^{(b)}$ & 4.1 & 0.41 & $140^{(b)}$ & 21 & 0.06 & $21^{(b)}$ & 25 & 0.13 \\
\hline $9.6 \mathrm{Ti}-3.3 \mathrm{Cr}$ & $84^{(b)}$ & 1.7 & 0.60 & 196 & 11 & 0.26 & $21^{(b)}$ & 15 & 0.09 \\
\hline
\end{tabular}

(a) From the equation $\mathrm{W}=\mathrm{Kt} \mathrm{t}^{\mathrm{n}}$, where $\mathrm{t}=$ time, days.

(b) Specimen began to lose weight after exposure time indicated. 
TABLE 11. SUMMIARY OF CORROSION RESULTS OF ROCKING-HEARTH-MELTED HIGH-PURITY NIOBIUM-BASE ALLOYS EXPOSED TO $680 \mathrm{~F}$ WATER

\begin{tabular}{|c|c|c|c|c|}
\hline Alloy & $\begin{array}{c}\text { Alloy Content } \\
\text { (Balance Niobium), } \\
\text { a/o }\end{array}$ & $\begin{array}{l}\text { Thermal-Neutron-Absorption } \\
\text { Cross Section, barns per atom }\end{array}$ & $\begin{array}{l}\text { Exposure Time, } \\
\text { days }\end{array}$ & $\begin{array}{c}\text { Total Weight Change, } \\
\text { mg per dm }\end{array}$ \\
\hline N1 & $100 \mathrm{Nb}$ & 1.15 & 224 & -531 \\
\hline $\mathrm{N} 40$ & $100 \mathrm{Nb}$ & 1.15 & 224 & -615 \\
\hline $\mathrm{N} 44$ & $100 \mathrm{Nb}$ & 1.15 & $84^{(a)}$ & Disintegrated \\
\hline N56 & $100 \mathrm{Nb}$ & 1.15 & 196 & -39 \\
\hline N2 & $1.1 \mathrm{Zr}$ & 1.14 & 140 & $\begin{array}{r}-20,400 \text { (disintegrated } \\
168 \text { days) }\end{array}$ \\
\hline N3 & $2.2 \mathrm{Zr}$ & 1.13 & 196 & $-1,780$ \\
\hline $\mathrm{N} 4$ & $5 \mathrm{Zr}(\mathrm{c})$ & 1.10 & 196 & $-1,450$ \\
\hline N5 & $10.2 \mathrm{Zr}$ & 1.05 & 196 & -3 \\
\hline N6 & $40 \mathrm{Zr}_{\mathrm{r}}(\mathrm{c})$ & 0.76 & 196 & 78 \\
\hline N8 & $65 \mathrm{Zr}(\mathrm{c})$ & 0.52 & 196 & $\begin{array}{l}-112 \text { (edge } \\
\text { cracking) }\end{array}$ \\
\hline N9 & $75 \mathrm{Zr}(\mathrm{c})$ & 0.42 & 196 & 128 \\
\hline N10 & $90 \mathrm{Zr}(\mathrm{c})$ & 0.27 & 196 & 142 \\
\hline N11 & $3.2 \mathrm{Ti}$ & 1.30 & 224 & $-1,030$ \\
\hline N12 & $10.5 \mathrm{Ti}$ & 1.60 & 224 & 76 \\
\hline N13 & $25.0 \mathrm{Ti}(\mathrm{c})$ & 2.30 & 224 & 48 \\
\hline N14 & $<0.02 \mathrm{Cr}$ & 1.15 & 224 & -387 \\
\hline N15 & $0.5 \mathrm{Cr}$ & 1.16 & 224 & -135 \\
\hline N48 & $0.5 \mathrm{Cr}$ & 1.16 & 196 & -495 \\
\hline N45 & $<0.08 \mathrm{Fe}$ & 1.15 & 196 & -182 \\
\hline$N 46$ & $0.3 \mathrm{Fe}$ & 1.16 & 112 & $-1,180$ \\
\hline N47 & $10 \mathrm{Fe}^{(\mathrm{c})}$ & 1.28 & $28(a)$ & $-2,000$ (cracked) \\
\hline N21 & $10.9 \mathrm{Zr}-5.1 \mathrm{Ti}$ & 1.24 & 224 & 60 \\
\hline $\mathrm{N} 22$ & $25 \mathrm{Zr}-5 \mathrm{Ti}(\mathrm{c})$ & 1.10 & 224 & $\begin{array}{l}-22 \text { (edge } \\
\text { cracking) }\end{array}$ \\
\hline N23 & $25 \mathrm{Zr}-15 \mathrm{Ti}(\mathrm{c})$ & 1.56 & 224 & 47 \\
\hline $\mathrm{N} 24$ & $25 \mathrm{Zr}-25 \mathrm{Ti}(\mathrm{c})$ & 2.04 & 224 & 47 \\
\hline $\mathrm{N} 25$ & $35 \mathrm{Zr}-5 \mathrm{Ti}(\mathrm{c})$ & 1.00 & 224 & 71 \\
\hline $\mathrm{N} 26$ & $35 \mathrm{Zr}-15 \mathrm{Ti}(\mathrm{c})$ & 1.50 & 224 & 59 \\
\hline N28 & $45 \mathrm{Zr}-5 \mathrm{Ti}(\mathrm{c})$ & 0.92 & 224 & 71 \\
\hline N29 & $10 \mathrm{Zr}-5 \mathrm{Mo}(\mathrm{c})$ & 1.13 & 224 & $17^{(b)}$ \\
\hline N30 & $35 \mathrm{Zr}-5 \mathrm{Mo}(\mathrm{c})$ & 0.88 & 224 & 53 \\
\hline N31 & $45 \mathrm{Zr}-5 \mathrm{Mo}(\mathrm{c})$ & 0.78 & 224 & 70 \\
\hline N32 & $35 \mathrm{Zr}-5 \mathrm{Al}^{(\mathrm{c})}$ & 0.76 & 196 & 62 \\
\hline N34 & $45 \mathrm{Zr}-5 \mathrm{Al}(\mathrm{c})$ & 0.67 & 196 & 60 \\
\hline N35 & $10 \mathrm{ZI}-5 \mathrm{Cr}^{(\mathrm{c})}$ & 1.14 & 196 & 48 \\
\hline N37 & $45 \mathrm{Cr}-5 \mathrm{Cr}(\mathrm{c})$ & 0.93 & 196 & 48 \\
\hline N38 & $10 \mathrm{Zr}-5 \mathrm{Fe}(\mathrm{c})$ & 1.12 & 196 & 44 \\
\hline N16 & $1.6 \mathrm{~V}$ & 1.18 & 224 & 111 \\
\hline
\end{tabular}


TABLE 11. (Continued)

\begin{tabular}{|c|c|c|c|c|}
\hline Alloy & $\begin{array}{c}\text { Alloy Content } \\
\text { (Balance Niobium), } \\
\text { a/o }\end{array}$ & $\begin{array}{l}\text { Thermal-Neutron-Absorption } \\
\text { Cross Section, barns per atom }\end{array}$ & $\begin{array}{c}\text { Exposure Time, } \\
\text { days }\end{array}$ & $\begin{array}{c}\text { Total weight Change, } \\
\text { mg per } \mathrm{dm}^{2} \\
\end{array}$ \\
\hline N49 & $2 \mathrm{~V}-2.5 \mathrm{Ti}$ & 1.34 & 196 & 88 \\
\hline N50 & $2 \mathrm{~V}-2.3 \mathrm{Mo}$ & 1.29 & 196 & 114 \\
\hline N51 & $2.2 \mathrm{~V}-0.54 \mathrm{Fe}$ & 1.24 & 196 & 79 \\
\hline N53 & $1.8 \mathrm{~V}-<0.02 \mathrm{Cr}$ & 1.19 & 196 & 58 \\
\hline N54 & $1.8 \mathrm{~V}-0.14 \mathrm{Al}$ & 1.19 & 196 & 88 \\
\hline N55 & $2.5 \mathrm{~V}-2.5 \mathrm{Zr}(\mathrm{c})$ & 1.22 & 112 & -243 \\
\hline N52 & $2.2 \mathrm{~V}-0.87 \mathrm{Ni}$ & 1.24 & $28^{(a)}$ & -100 \\
\hline N17 & $2.3 \mathrm{Zr}-4 \mathrm{~V}$ & 1.26 & 196 & 60 \\
\hline N18 & $25 \mathrm{Zr}-5 \mathrm{~V}(\mathrm{c})$ & 1.10 & 196 & $\begin{array}{l}-284 \text { (edge } \\
\text { cracking) }\end{array}$ \\
\hline N19 & $35 Z_{r}-5 \mathrm{~V}(\mathrm{c})$ & 1.00 & 196 & -352 (pitted) \\
\hline N20 & $45 \mathrm{Zr}-5 \mathrm{~V}(\mathrm{c})$ & 0.90 & 196 & 60 \\
\hline N57 & $1 \mathrm{Ce}^{(\mathrm{c})}$ & 1.13 & 56 & $-1,180(a)$ \\
\hline N59 & $1 \mathrm{Y}^{(\mathrm{c})}$ & 1.15 & 56 & $-1,020$ \\
\hline N60 & $5 Y(c)$ & 1.16 & 56 & $-6,420$ (a) \\
\hline N61 & $1 \mathrm{Ni}(\mathrm{c})$ & 1.18 & 28 & $4^{(b)}$ \\
\hline N62 & $2.5 \mathrm{Ni}(\mathrm{c})$ & 1.23 & $7(a)$ & Cracked \\
\hline N63 & $5 \mathrm{Ni}(\mathrm{c})$ & 1.32 & $7(a)$ & Disintegrated \\
\hline N64 & $1 \mathrm{Pd}(\mathrm{c})$ & 1.21 & $28^{(a)}$ & -834 (split in two) \\
\hline N70 & $5 \mathrm{~V}-2.5 \mathrm{Al}^{(\mathrm{c})}$ & 1.32 & 56 & 58 \\
\hline N68 & $5 \mathrm{~V}-2.5 \mathrm{Cr}(\mathrm{c})$ & 1.39 & 56 & 60 \\
\hline N65 & $5 \mathrm{~V}-2.5 \mathrm{Ti}(\mathrm{c})$ & 1.49 & 56 & 51 \\
\hline-- & Zircaloy-2 & 0.19 & 200 & $66^{(\mathrm{d})}$ \\
\hline
\end{tabular}

(a) Specimens off test.

(b) Specimens losing weight.

(c) Nominal composition.

(d) Reference (5). 
TABLE 12. RATE CONSTANTS FOR THE CORROSION OF ROCKING-HEARTH ARC-MELTED HIGH-PURITY NIOBIUM-BASE ALLOYS EXPOSED TO $680 \mathrm{~F}$ WATER

\begin{tabular}{|c|c|c|c|c|}
\hline Alloy & $\begin{array}{c}\text { Alloy Content } \\
\text { (Balance Niobium), } \\
\text { a/o }\end{array}$ & $\begin{array}{c}\text { Exposure Time, } \\
\text { days }\end{array}$ & $\begin{array}{l}\mathrm{K}^{(\mathrm{a})}, \\
\mathrm{mg} \text { per } \mathrm{dm}^{2} \text {, } \\
1 \text { Day }\end{array}$ & $\begin{array}{c}n, \\
\text { Dimensionless } \\
\end{array}$ \\
\hline $\mathrm{N} 1$ & $100 \mathrm{Nb}$ & $112^{(c)}$ & 54 & 0.21 \\
\hline $\mathrm{N} 40$ & $100 \mathrm{Nb}$ & $112^{(c)}$ & 42 & 0.30 \\
\hline N56 & $100 \mathrm{Nb}$ & $112^{(c)}$ & 39 & $0.18(b)$ \\
\hline N44 & $100 \mathrm{Nb}$ & $3^{(c)}$ & -- & -- \\
\hline N2 & $1.1 \mathrm{Zr}$ & $3^{(c)}$ & -- & -- \\
\hline N3 & $2.2 \mathrm{Zr}$ & $3(c)$ & -- & -- \\
\hline N4 & $5 \mathrm{Zr}^{(\mathrm{d})}$ & $28(\mathrm{c})$ & 19 & 0.43 \\
\hline N5 & $10.2 \mathrm{Zr}$ & 56 (c) & 5.5 & $0.38^{(b)}$ \\
\hline N6 & $40 \mathrm{Zr}(\mathrm{d})$ & 196 & 6.0 & 0.49 \\
\hline N8 & $65 \mathrm{Zn}(\mathrm{d})$ & $112^{(c)}$ & 7.5 & 0.53 \\
\hline N9 & $75 \mathrm{Zr}^{(\mathrm{d})}$ & 196 & 17 & 0.39 \\
\hline N10 & $90 \mathrm{Zr}^{(\mathrm{d})}$ & 196 & 6.4 & 0.59 \\
\hline N11 & $3.2 \mathrm{Ti}$ & $42^{(c)}$ & 37 & 0.11 \\
\hline $\mathrm{N} 12$ & $10.5 \mathrm{Ti}$ & 224 & 9.0 & 0.40 \\
\hline N13 & $25 \mathrm{Ti}(\mathrm{d})$ & 224 & 8.0 & 0.33 \\
\hline N14 & $<0.02 \mathrm{Cr}$ & $42^{(c)}$ & 37 & 0.30 \\
\hline N15 & $0.5 \mathrm{Cr}$ & $14^{(c)}$ & 27 & 0.32 \\
\hline $\mathrm{N} 48$ & $0.5 \mathrm{Cr}$ & $14^{(c)}$ & 28 & 0.23 \\
\hline $\mathrm{N} 45$ & $<0.08 \mathrm{Fe}$ & $28(c)$ & 36 & 0.24 \\
\hline $\mathrm{N} 46$ & $0.3 \mathrm{Fe}$ & $3^{(c)}$ & -- & -- \\
\hline N47 & $10 \mathrm{Fe}^{(\mathrm{d})}$ & $3(c)$ & -- & -- \\
\hline $\mathrm{N} 21$ & $10.9 \mathrm{Zr}-5.1 \mathrm{Ti}$ & 196 & 9.5 & 0.36 \\
\hline $\mathrm{N} 22$ & $25 \mathrm{Zr}-5 \mathrm{Ti}(\mathrm{d})$ & $84^{(c)}$ & 21 & $0.23(b)$ \\
\hline $\mathrm{N} 23$ & $25 \mathrm{Zr}-15 \mathrm{Ti}(\mathrm{d})$ & 196 & 12 & $0.32^{(b)}$ \\
\hline $\mathrm{N} 24$ & $25 \mathrm{Zr}-25 \mathrm{Ti}(\mathrm{d})$ & 196 & 5.0 & 0.42 \\
\hline N25 & $35 \mathrm{Zr}-5 \mathrm{Ti}^{(\mathrm{d})}$ & 196 & 7.3 & 0.42 \\
\hline N26 & $35 \mathrm{Zr}-15 \mathrm{Ti}(\mathrm{d})$ & 196 & 5.5 & 0.46 \\
\hline N28 & $45 \mathrm{Z}-5 \mathrm{Ti}(\mathrm{d})$ & 196 & 4.4 & 0.49 \\
\hline $\mathrm{N} 29$ & $10 \mathrm{Zr}-5 \mathrm{Mo}^{(\mathrm{d})}$ & $112^{(c)}$ & 3.9 & 0.44 \\
\hline N30 & $35 \mathrm{Zr}-5 \mathrm{Mo}^{(\mathrm{d})}$ & 196 & 12 & 0.30 \\
\hline N31 & $45 \mathrm{Zr}-5 \mathrm{Mo}(\mathrm{d})$ & 196 & 5.2 & 0.50 \\
\hline N32 & $35 \mathrm{Zr}-5 \mathrm{Al}(\mathrm{d})$ & 196 & 15 & 0.26 \\
\hline N34 & $45 \mathrm{Zr}-5 \mathrm{Al}(\mathrm{d})$ & 196 & 4.5 & 0.53 \\
\hline N35 & $10 \mathrm{Zr}-5 \mathrm{Cr}^{(\mathrm{d})}$ & 196 & 7.5 & 0.41 \\
\hline N37 & $45 \mathrm{Zr}-5 \mathrm{Cr}$ & 196 & 5.6 & 0.42 \\
\hline N38 & $10 \mathrm{Zr}-5 \mathrm{Fe}(\mathrm{d})$ & 196 & 8.0 & 0.33 \\
\hline N16 & $1.6 \mathrm{~V}$ & 224 & 20 & $0.30^{(b)}$ \\
\hline
\end{tabular}


TABLE 12. (Continued)

\begin{tabular}{|c|c|c|c|c|}
\hline Alloy & $\begin{array}{c}\text { Alloy Content } \\
\text { (Balance Niobium), } \\
\mathrm{a} / \mathrm{o}\end{array}$ & $\begin{array}{c}\text { Exposure Time, } \\
\text { days }\end{array}$ & $\begin{array}{c}\mathrm{K}^{(\mathrm{a})}, \\
\mathrm{mg} \text { per } \mathrm{dm}^{2}, \\
1 \text { Day }\end{array}$ & $\begin{array}{c}\mathrm{n}, \\
\text { Dimensionless } \\
\end{array}$ \\
\hline N49 & $2 \mathrm{~V}-2.5 \mathrm{Ti}$ & 196 & 10.0 & 0.42 \\
\hline N50 & $2 \mathrm{~V}-2.3 \mathrm{Mo}$ & 196 & 7.2 & 0.52 \\
\hline N51 & $2.2 \mathrm{~V}-0.54 \mathrm{Fe}$ & 196 & 19 & 0.29 \\
\hline N53 & $1.8 \mathrm{~V}-<0.02 \mathrm{Cr}$ & 196 & 11 & $0.34^{(b)}$ \\
\hline N54 & $1.8 \mathrm{~V}-0.14 \mathrm{Al}$ & 196 & 20 & 0.28 \\
\hline N55 & $2.5 \mathrm{~V}-2.5 \mathrm{Zr}(\mathrm{d})$ & $7^{(c)}$ & $\cdots$ & -- \\
\hline N52 & $2.2 \mathrm{~V}-0.87 \mathrm{Ni}$ & $3(c)$ & -- & - \\
\hline N17 & $2.3 \mathrm{Zr}-4 \mathrm{~V}$ & 196 & 2.8 & 0.55 \\
\hline N 18 & $25 \mathrm{Zr}-5 \mathrm{~V}^{(\mathrm{d})}$ & $28^{(c)}$ & 18 & 0.35 \\
\hline N19 & $35 \mathrm{Zr}-5 \mathrm{~V}(\mathrm{~d})$ & $84^{(c)}$ & 14 & 0.38 \\
\hline $\mathrm{N} 20$ & $45 \mathrm{Zr}-5 \mathrm{~V}(\mathrm{~d})$ & 112 & 3.0 & $0.52^{(b)}$ \\
\hline N57 & $1 \mathrm{Ce}^{(\mathrm{d})}$ & $14^{(c)}$ & $\cdots$ & $\cdots$ \\
\hline N59 & $1 \mathrm{Y}(\mathrm{d})$ & $3^{(c)}$ & -- & -- \\
\hline N60 & $5 Y(d)$ & $3^{(c)}$ & -- & -- \\
\hline $\mathrm{N} 61$ & $1 \mathrm{Ni}(\mathrm{d})$ & $3^{(c)}$ & $\cdots$ & $\cdots$ \\
\hline N62 & $2.5 \mathrm{Ni}^{(\mathrm{d})}$ & $3^{(c)}$ & $\rightarrow$ & - \\
\hline N63 & $5 \mathrm{Ni}(\mathrm{d})$ & $3^{(c)}$ & $\cdots$ & -- \\
\hline N64 & $1 \mathrm{Pd}^{(\mathrm{d})}$ & $28(c)$ & 170 & 0.85 \\
\hline N70 & $5 \mathrm{~V}-2.5 \mathrm{Al}^{(\mathrm{d})}$ & 56 & 6.5 & $0.53(b)$ \\
\hline N68 & $5 \mathrm{~V}-2.5 \mathrm{Cr}(\mathrm{d})$ & 56 & 7.0 & $0.53(b)$ \\
\hline N65 & $5 \mathrm{~V}-2.5 \mathrm{Ti}^{(\mathrm{d})}$ & 56 & 7.5 & 0.47 \\
\hline
\end{tabular}

(a) From the equation $\mathrm{W}=\mathrm{Kt}^{\mathrm{n}}$, where $\mathrm{t}=$ time, days.

(b) Slope obtained from erratic data.

(c) Specimen began to lose weight after exposure time indicated.

(d) Nominal composition. 
A binary 65 a/o zirconium alloy and ternary alloys containing 25 a/o zirconium plus 5 a/o titanium or 5 a/o vanadium also were losing weight, apparently at edge cracks. The cracks probably were present after fabrication and were not entirely removed during sample preparation. Pitting was observed on a 35 a/o zirconium-5 a/o vanadium alloy.

One set of the arc-melted, unalloyed control samples (N44 in Table 10) processed with these alloys began to flake and lose weight rapidly after 7 days ' exposure in much the same fashion as the unalloyed commercial-purity niobium specimen. One of the specimens was completely oxidized after 84 days' exposure. The other three sets of unalloyed control samples (N1, N40, and N56 in Table 11) showed lower weight gains after 84 days' exposure. The variance among these data suggests that the interstitial content of niobium may have a profound effect on its water corrosion resistance. It would appear, for example, from the weight-gain data that the interstitial content of the N44 material had been raised to the level of that for commercial-purity niobium as a result of contamination during melting and fabrication. Hardness measurements (see Table 3) on each of the unalloyed high-purity samples indicated that only minor differences existed in the total interstitial content of all four of these control samples. The wide variance in corrosion rates suggests, therefore, that one or more of the contaminants has a greater detrimental effect on the corrosion resistance of niobium than the others.

While the high-purity unalloyed niobium exhibits longer corrosion life than does commercial-purity material, there appears to be little effect of purity of the base metal on the corrosion behavior of niobium alloys. Comparison of the results obtained in $680 \mathrm{~F}$ water for alloys of similar composition prepared from the two melting stocks reveals no significant difference in weight change (see Tables 8,9 , and 11).

\section{Selective Attack}

Visual examination revealed that several of the niobium alloys failed pr, raturely from cracking or other forms of selective attack during corrosion. The microstructure of two of the specimens was examined to gain an insight into the mode of failure. These specimens were commercial-purity unalloyed niobium and a 7.2 a/o molybdenum alloy. Corrosion results for these alloys were presented in Tables 8 and 9, respectively.

The appearance of the microstructures of these specimens is shown in Figure 6. The unalloyed niobium had been exposed 28 days to $680 \mathrm{~F}$ water. A companion specimen in the same test was completely oxidized after 42 days' exposure. Laminar-type attack is evident from the oxide pattern in the structure of the unalloyed niobium. Attack apparently occurred either at grain boundaries, which were elongated during rolling, or more probably at cold shuts introduced during cold reduction. The complete oxidation of the companion specimen probably occurred when the selective attack progressed to such an extent that the specimen was reduced to small metal particles. The particles, in turn, were completely oxidized because of their large surface-to-volume ratio.

The 7.2 a/o molybdenum alloy cracked after 70 days' exposure to $750 \mathrm{~F}$ steam. A duplicate specimen cracked after 224 days' exposure to $680 \mathrm{~F}$ water. The cracking was found to be transgranular in nature. The reasons for the cracking are not yet apparent. 


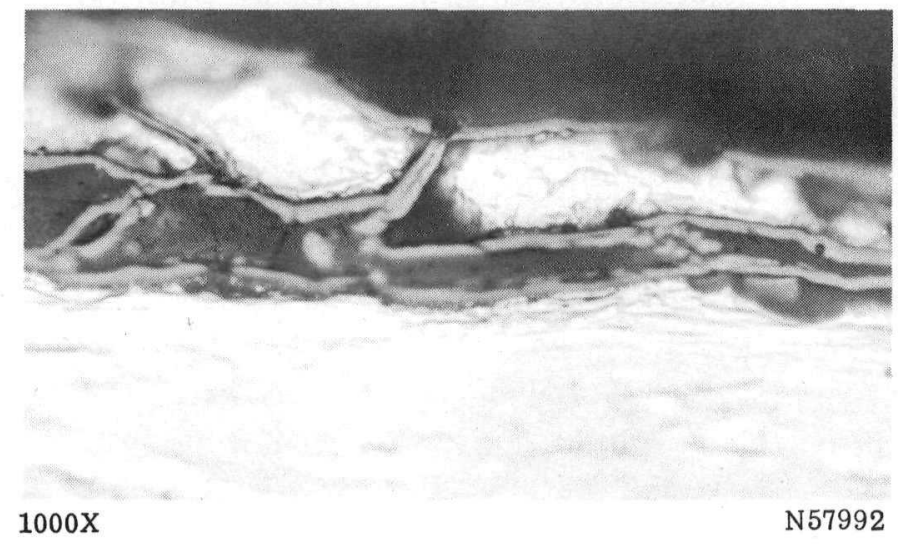

a. Unalloyed Commercial-Purity Niobium Exposed 28 Days to $680 \mathrm{~F}$ Water

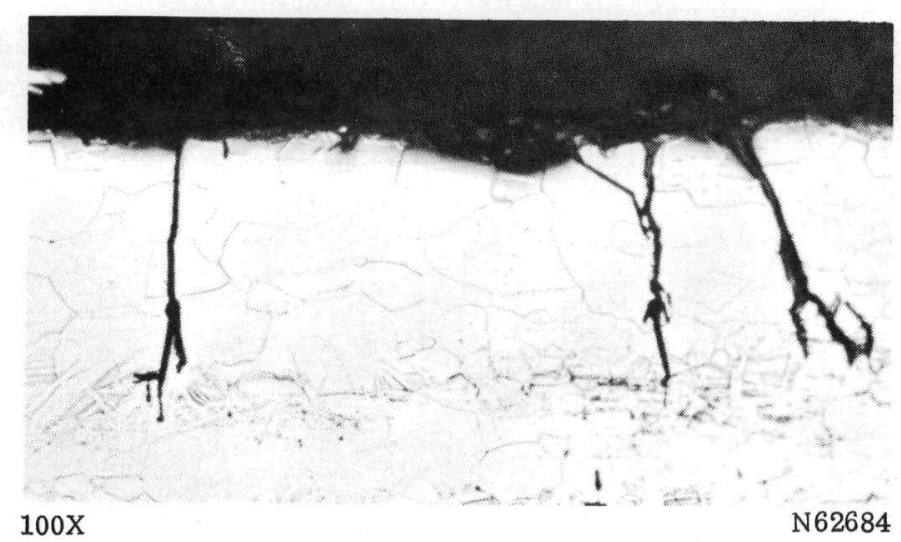

b. Niobium-7.2 a/o Molybdenum Exposed 70 Days to $750 \mathrm{~F}$ Ste am

FIGURE 6. SELECTIVE ATTACK IN NIOBIUM SAMPLES EXPOSED TO HIGH-TEMPERATURE WATER AND STEAM Note lamellar separation in unalloyed niobium and transgranular cracking in alloy. 


\section{Oxygen Contamination}

Samples of each commercial-purity niobium-base alloy were withdrawn for metallographic evaluation after 42- and 196-day exposures to $680 \mathrm{~F}$ water and their oxide-scale thicknesses were measured where these could be retained in polishing. For selected alloys, Knoop-hardness traverses were obtained and used to calculate the depth of contamination hardening. On the assumption that this hardening was due entirely to oxygen absorbed from the water-corrosion reaction, the contamination coefficients for oxygen in the alloys were calculated*. In alloys where no reaction occurs with the diffusing oxygen, i.e., in unalloyed niobium and in alloys with molybdenum, tungsten, and vanadium, the contamination rates equal the oxygen-diffusion rates. Table 13 summarizes the results obtained.

The oxide scales on the corroded alloys were generally found to increase in thickness and porosity with increasing corrosion rates. The range of scale thicknesses ranged from less than 0.1 mil for the most corrosion-resistant alloys (niobium- 45.7 a/o zirconium and niobium- 28.2 a/o titanium- 6.1 a/o chromium) to about $0.8 \mathrm{mil}$ for the least corrosion-resistant alloy (niobium-4. 7 a/o tungsten) remaining on test after 196 days. It should be noted, however, that this tungsten alloy was losing weight rapidly near the end of the corrosion test period. Hence, its true scale thickness was probably much greater than $0.8 \mathrm{mil}$.

The calculated contamination coefficient for oxygen in unalloyed niobium in $680 \mathrm{~F}$ water was found to be $2.7 \times 10^{-12} \mathrm{~cm}^{2}$ per sec. This value is in good agreement with a value of $4.5 \times 10^{-12} \mathrm{~cm}^{2}$ per sec obtained by extrapolation of the diffusion data of Ang(6) to this temperature. The effect of alloying additions on the contamination rate of oxygen in niobium is more clearly shown by reference to Figure 7. As shown, additions of titanium, vanadium, and zirconium reduce the contamination rate of oxygen in niobium significantly. Both titanium and zirconium reduce the rates by a factor of about 40 . This corresponds to about a sixfold reduction in the depth of contamination. Vanadium, molybdenum, and tungsten additions, in that order, have increasingly less effect on reducing the depth of contamination. It is noted, however, that even the least corrosionresistant alloys were contaminated to a depth of only about 5 mils after 196 days' exposure.

Micrographs of scale-metal interfaces on several corroded niobium alloys are shown in Figure 8. The decrease in thickness and porosity of the scale is apparent as the corrosion resistance changes from poor (niobium-4. 7 a/o tungsten) to excellent (niobium-45. 7 a/o zirconium).

\section{Hydrogen Absorption}

It is known that zirconium alloys absorb hydrogen during corrosion in hightemperature water. A similar effect might be expected with niobium since it also is an excellent getter for reactive gases. Accordingly, hydrogen analyses were obtained on unalloyed niobium and several alloys after exposures ranging up to 252 days for the three test conditions. These data are presented in Table 14.

*The techniques used for calculating diffusion coefficients of oxygen in niobium from hardness data were described in Reference (3). 
TABLE 13. MET ALLOGRAPHIC DATA ON COMMERCIAL-PURITY NIOBIUM-BASE ALLOYS EXPOSED TO $680 \mathrm{~F}$ WATER

\begin{tabular}{|c|c|c|c|c|c|c|c|c|}
\hline \multirow[b]{2}{*}{ Alloy } & \multirow[b]{2}{*}{$\begin{array}{c}\text { Alloy Content } \\
\text { (Balance Niobium), } \\
\text { a/o }\end{array}$} & \multicolumn{4}{|c|}{7 to 42 Days of Exposure } & \multicolumn{3}{|c|}{196 Days of Exposure } \\
\hline & & $\begin{array}{c}\text { Exposure } \\
\text { Time, } \\
\text { days }\end{array}$ & $\begin{array}{l}\text { Thickness } \\
\text { of Adhering } \\
\text { Scale, mils }\end{array}$ & $\begin{array}{c}\text { Diffusion } \\
\text { Coefficient } \\
\text { of Oxygen }(\mathrm{a}) \text {, } \\
\mathrm{cm}^{2} \text { per sec }\end{array}$ & $\begin{array}{c}\text { Depth of } \\
\text { Contamination } \\
\text { Hardening(b), } \\
\text { mils }\end{array}$ & $\begin{array}{l}\text { Thickness } \\
\text { of Adhering } \\
\text { Scale, mils }\end{array}$ & $\begin{array}{c}\text { Diffusion } \\
\text { Coefficient } \\
\text { of Oxygen }^{(a)} \text {, } \\
\text { cm }^{2} \text { per sec }\end{array}$ & $\begin{array}{c}\text { Depth of } \\
\text { Contamination } \\
\text { Hardening(b) } \\
\text { mils }\end{array}$ \\
\hline-- & $100 \mathrm{Nb}$ & 28 & 0.3 & $27 \times 10^{-12}$ & 2.4 & -- & -- & -- \\
\hline 150 & $4.4 \mathrm{~V}$ & 42 & (c) & -- & $-\infty$ & -. & $5 \times 10^{-13}$ & 2.8 \\
\hline 147 & $6.6 \mathrm{~V}$ & 42 & (c) & -- & -- & 0.2 & -- & -- \\
\hline 149 & $10.7 \mathrm{~V}$ & 42 & 0.1 & -- & -- & -. & $2 \times 10^{-13}$ & 1.6 \\
\hline 158 & $13.7 \mathrm{~V}$ & 42 & (c) & 1. $3 \times 10^{-12}$ & 3.2 & -. & $1 \times 10^{-12}$ & 4 \\
\hline 151 & $24.2 \mathrm{~V}$ & 42 & (c) & -- & - & 0.2 & $1.1 \times 10^{-12}$ & $<4$ \\
\hline 154 & $7.4 \mathrm{Mo}$ & 42 & (c) & $1.3 \times 10^{-12}$ & 2.4 & 0.5 & $1.6 \times 10^{-12}$ & $<4$ \\
\hline 163 & $1.1 \mathrm{~W}$ & 42 & 0.15 & -- & -- & -- & - & -- \\
\hline 164 & $4.7 \mathrm{~W}$ & 42 & $0.1-0.2$ & -- & -- & 0.8 & -- & -- \\
\hline 165 & $9.6 \mathrm{~W}$ & 7 & 0.6 & $2 \times 10^{-12}$ & 1.6 & -- & - & -- \\
\hline 169 & $4.9 \mathrm{Fe}$ & 42 & 0.1 & -- & -- & -- & - & -- \\
\hline 138 & $10.5 \mathrm{Zr}$ & 42 & 0.02 & -. & $\cdots$ & 0.2 & $7 \times 10^{-14}$ & 1.6 \\
\hline 139 & $26.1 \mathrm{Zr}$ & 42 & (c) & -. & -- & - & $3 \times 10^{-14}$ & 0.8 \\
\hline 140 & $35.7 \mathrm{Zr}$ & 42 & 01 & -- & $-\cdot$ & -- & - & -- \\
\hline 141 & $45.7 \mathrm{Zr}$ & 42 & $0.02-0.03$ & $6.1 \times 10^{-13}$ & 0.8 & 0.05 & $7 \times 10^{-14}$ & 1.2 \\
\hline 142 & $9.4 \mathrm{~T}_{1}$ & 42 & $0.1-0.3$ & -- & -- & 0.2 & $7 \times 10^{-14}$ & 1.6 \\
\hline 144 & $24.3 \mathrm{Tl}$ & 42 & (c) & $<5 \times 10^{-13}$ & $<0.4$ & -- & $5 \times 10^{-14}$ & 0.8 \\
\hline 146 & $33.8 \mathrm{~T}_{1}$ & 42 & 0.05 & -- & -- & 0.1 & -- & - \\
\hline 177 & $28.2 \mathrm{~T} 1-6.1 \mathrm{Cr}$ & 42 & (c) & $<5 \times 10^{-13}$ & $<0.4$ & 0.07 & $5 \times 10^{-14}$ & 1.2 \\
\hline 172 & $12 \mathrm{~T}_{1}-4.2 \mathrm{Mo}$ & 42 & (c) & $<5 \times 10^{-13}$ & $<0.4$ & -- & -- & -- \\
\hline 174 & $23.1 \mathrm{~T} 1-7.8 \mathrm{Mo}$ & 42 & (c) & $\ldots$ & -- & 0.13 & $5 \times 10^{-14}$ & 0.8 \\
\hline 180 & $22.6 \mathrm{~T}_{1}-11 \mathrm{~V}$ & 42 & (c) & -- & - & 0.1 & -- & -- \\
\hline
\end{tabular}

(a) Calculated from hardness-traverse data.

(b) Distance from surface where hardness returns to within $10 \mathrm{KHN}$ of base hardness.

(c) Scale thickness not estimated due to poor preservation of sample edges. 


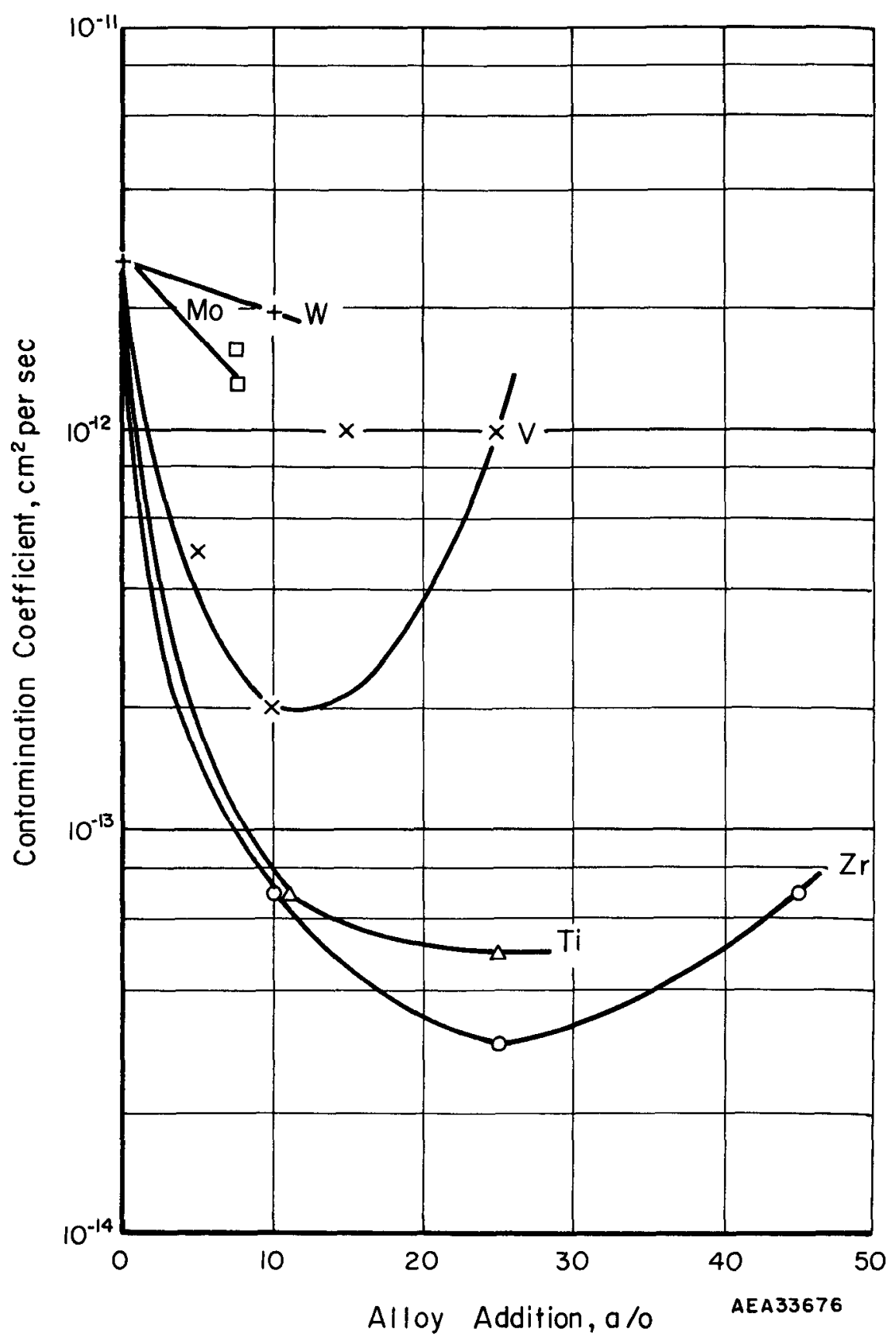

FIGURE 7. EFFECTS OF ALLOYING ON THE CONTAMINATION RATE OF NIOBIUM EXPOSED TO 680 F WATER FOR 196 DAYS 


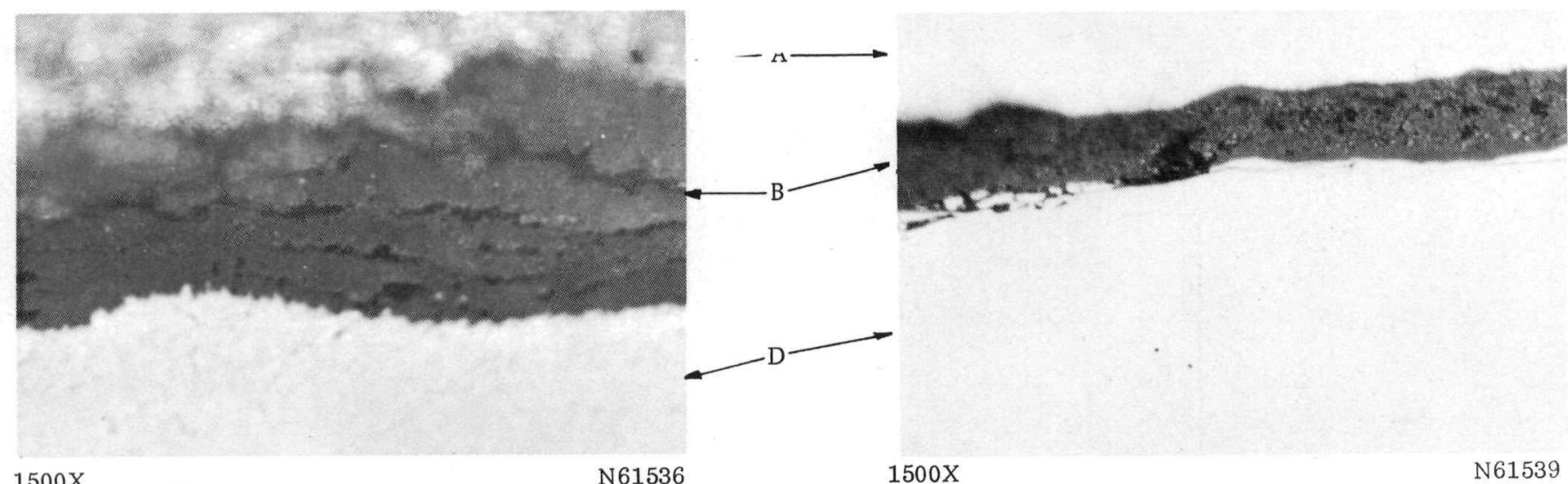

a. Niobium-4. 7 a/o Tungsten

b. Niobium-10. 5 a/o Zirconium

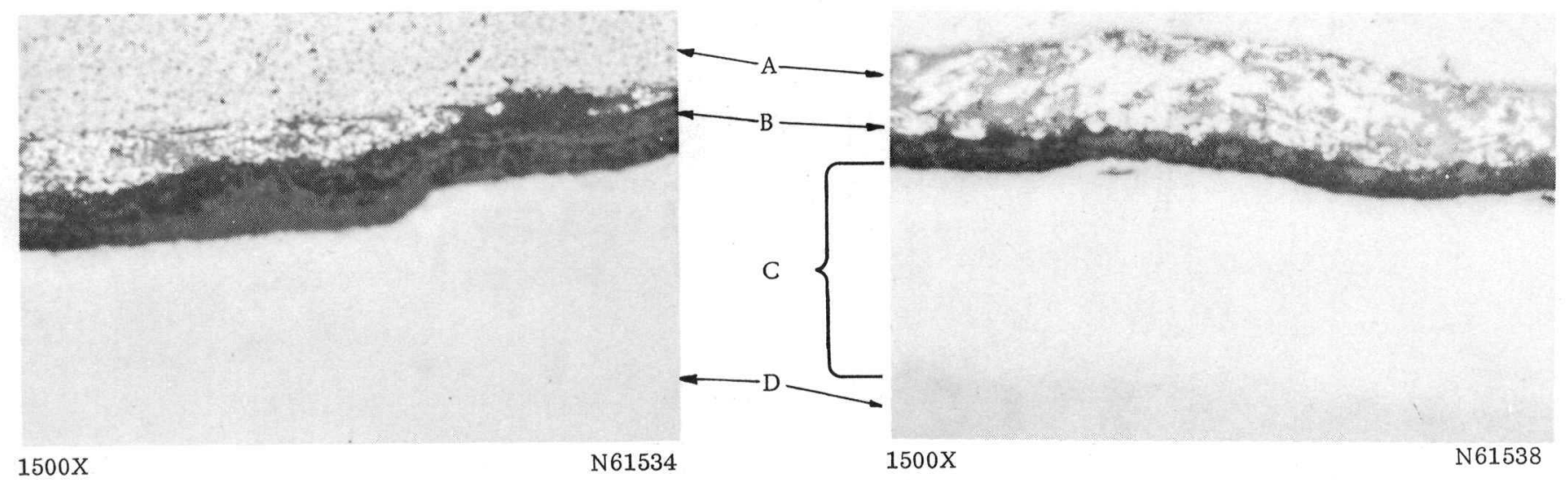

c. Niobium-6. 6 a/o Vanadium

d. Niobium-33.8 a/o Titanium

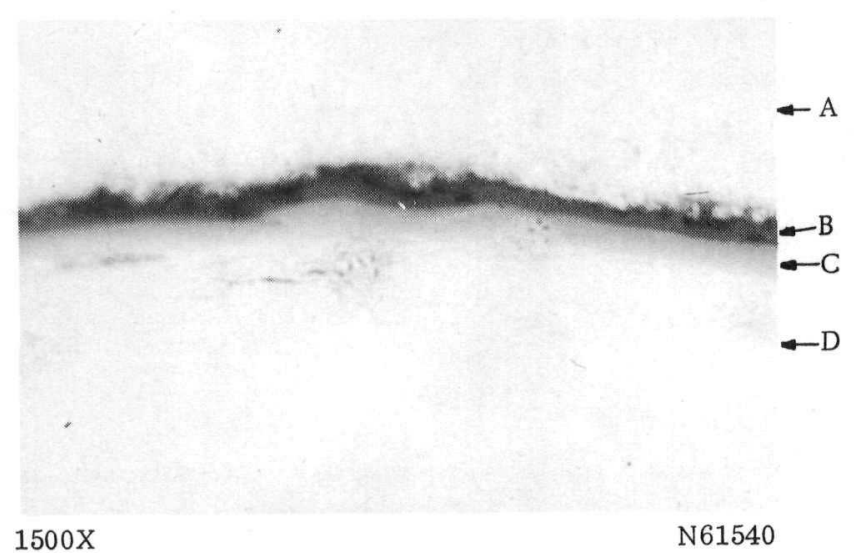

e. Niobium-45. 7 a/o Zirconium

FIGURE 8. MICROSTRUCTURES OF CORRODED NIOBIUM ALLOYS

All alloys were exposed 196 days to $680 \mathrm{~F}$ water.

A is backup material; B is scale; C is subscale;

$D$ is unaffected base. 
TABLE 14. HYDROGEN ANALYSES OF ALLOYS AFTER VARIOUS EXPOSURES TO HOT WATER AND STEAM

\begin{tabular}{|c|c|c|c|c|c|c|c|c|}
\hline \multirow[b]{3}{*}{ Alloy } & \multirow{3}{*}{$\begin{array}{c}\text { Alloy Content } \\
\text { (Balance Niobium), } \\
\text { a/o }\end{array}$} & \multirow{3}{*}{$\begin{array}{l}\text { Type of } \\
\text { Nlobium } \\
\text { Base }^{(a)}\end{array}$} & \multirow{2}{*}{\multicolumn{2}{|c|}{ Corrosion-Test Conditions }} & \multirow{3}{*}{$\begin{array}{c}\text { Weight Change } \\
\text { Durıng Water } \\
\text { Exposure, } \\
\text { mg per dm² }\end{array}$} & \multicolumn{3}{|c|}{ Hydrogen Content } \\
\hline & & & & & & \multirow{2}{*}{$\begin{array}{l}\text { Before } \\
\text { Corrosion, } \\
\text { ppm }\end{array}$} & \multicolumn{2}{|c|}{$\begin{array}{c}\text { After } \\
\text { Corrosion } \\
\end{array}$} \\
\hline & & & F & days & & & PPM & $\mathrm{Mg}$ per $\mathrm{Dm}^{2}$ \\
\hline \multirow[t]{2}{*}{--} & $100 \mathrm{Nb}$ & C.P. & 600 & 252 & -3740 & $<2$ & 224 & 4.4 \\
\hline & & C.P. & 680 & 28 & -5210 & $<2$ & 590 & 5.9 \\
\hline \multirow[t]{4}{*}{--} & $100 \mathrm{Nb}^{(b)}$ & H.P. & 600 & 252 & $64^{(c)}$ & 3 & 11 & 1.2 \\
\hline & & H.P. & 680 & 224 & -982 & 3 & 62 & 6.8 \\
\hline & & H. P & 750 & 168 & -5280 & 3 & 211 & 21.5 \\
\hline & & H. P. & 750 & 224 & -5400 & 3 & 225 & 23.2 \\
\hline $\mathrm{N} 44$ & $100 \mathrm{Nb}$ & H. P. & 680 & 84 & -2030 & -- & 944 & 29.7 \\
\hline 150 & $4.4 \mathrm{~V}$ & C.P. & 680 & 196 & 42 & -- & 5 & 0.18 \\
\hline 147 & $6.6 \mathrm{~V}$ & C.P. & 680 & 196 & 73 & -- & 18 & 0.67 \\
\hline 148 & $8.9 \mathrm{~V}$ & C.P. & 680 & 196 & 59 & -- & 6 & 0.24 \\
\hline 149 & $10.7 \mathrm{~V}$ & C.P. & 680 & 196 & 78 & -- & 30 & 1.1 \\
\hline \multirow[t]{3}{*}{$\mathrm{NL}-2$} & $12.6 \mathrm{~V}$ & H. P. & 600 & 252 & 45 & 7 & 5 & 0.22 \\
\hline & & H.P. & 680 & 224 & 61 & 7 & 31 & 1.3 \\
\hline & & H. P. & 750 & 224 & 84 & 7 & 44 & 1.9 \\
\hline 158 & $13.7 \mathrm{~V}$ & C.P. & 680 & 196 & 50 & -- & 8 & 0.37 \\
\hline 151 & $24.2 \mathrm{~V}$ & C.P. & 680 & 196 & 0 & -- & 5 & 0.18 \\
\hline 138 & $10.5 \mathrm{Zr}$ & C.P. & 680 & 196 & 67 & - & 18 & 0.48 \\
\hline 141 & $45.7 \mathrm{Zr}$ & C.P. & 680 & 42 & 16 & 35 & 61 & 2.2 \\
\hline 163 & $1.1 \mathrm{~W}$ & C.P. & 680 & 196 & -260 & -- & 34 & 1.4 \\
\hline 164 & $4.7 \mathrm{~W}$ & C.P. & 680 & 196 & -2930 & -- & 140 & 5.5 \\
\hline NL -3 & $7.2 \mathrm{Mo}$ & H. P. & 680 & 224 & -96 & 19 & 422 & 8.5 \\
\hline 154 & $7.4 \mathrm{Mo}$ & C. P. & 680 & 196 & 62 & -- & 38 & 1.5 \\
\hline 169 & $4.9 \mathrm{Fe}$ & C.P. & 750 & 84 & -283 & -- & 388 & 13.5 \\
\hline N47 & $10 \mathrm{Fe}$ & H. P. & 680 & 28 & -760 & -- & 511 & 13.5 \\
\hline 142 & $9.4 \mathrm{~T}_{1}$ & C.P. & 680 & 196 & 65 & -- & 24 & 0.86 \\
\hline \multirow[t]{2}{*}{177} & $28.2 \mathrm{Tl}-6.1 \mathrm{Cr}$ & C.P. & 680 & 42 & 10 & -- & 33 & 1.4 \\
\hline & & & 680 & 196 & 20 & - & 29 & 1.2 \\
\hline N52 & $2.2 \mathrm{~V}-0.87 \mathrm{~N} 1$ & H.P & 680 & 56 & -738 & -- & 1660 & 32.1 \\
\hline
\end{tabular}

(a) C P desıgnates commercial-purity niobium base, H.P. designates high-purity niobium base.

(b) Tested in as-received electron-beam-melted condition.

(c) Losing weight, maximum gain was $24.8 \mathrm{mg}$ per $\mathrm{dm}^{2}$ at 28 days. 
Analyses of the unalloyed niobium revealed hydrogen contents ranging from 11 to $944 \mathrm{ppm}$. In general, hydrogen content increased with increasing corrosion attack, thus indicating that the source of the hydrogen was the corrosion reaction. On this assumption, the hydrogen contents were recalculated on the basis of amount absorbed per unit of surface area. The resulting values ranged between 1.2 and $29.7 \mathrm{mg}$ per $\mathrm{dm}^{2}$ and again indicated that hydrogen absorption increased with increasing corrosion.

In some instances, hydrogen analyses were not obtained prior to corrosion testing because sample materials were limited. The maximum content found in any specimen before corrosion was $35 \mathrm{ppm}$. Since all specimens were vacuum annealed prior to corrosion testing, it appears probable that none of the alloys contained more than $35 \mathrm{ppm}$ hydrogen. Thus it is apparent from Table 14 that hydrogen absorption in the vanadium alloys was quite low. Hydrogen pickup in the zirconium and titanium binaries and the 28 a/o titanium-6 a/o chromium ternary also was low, while that in the iron, molybdenum, and tungsten alloy was moderately high and that in the 2.2 a/o vanadium-0.87 a/o nickel alloy was very high. In all instances, high hydrogen absorption could be correlated with poor corrosion resistance.

\section{Correlation of Corrosion-Test Results}

For purposes of discussion, the $680 \mathrm{~F}$ water corrosion behavior of all of the alloys tested is summarized in Table 15 and compared with the behavior of the most-corrosionresistant unalloyed niobium sample and with Zircaloy-2, after comparable exposure periods. Table 16 contains a similar comparison for the alloys tested in $750 \mathrm{~F}$ steam.

As is apparent from Table 15, the weight changes for six unalloyed niobium samples in $680 \mathrm{~F}$ water varied considerably. Highest corrosion rates were observed for the commercial-purity niobium which disintegrated in 42 days. While lower rates were obtained for the higher purity samples, the variance was still great. These values ranged from disintegration after 84 days, for the "worst" samples, to weight losses of $39 \mathrm{mg}$ per $\mathrm{dm}^{2}$ after 196 days for the "best" samples.

No significant effects of base-metal purity were observed on the corrosion behavior of the alloys. This is apparent by comparison of the data in Table 15 for binary alloys, made with both bases, containing about 10 a/o zirconium, 10 a/o titanium, 13 a/o vanadium, and 7 a/o molybdenum, as well as for several ternary titanium-molybdenum alloys.

Of the binary-alloy additions studied, titanium, vanadium, and zirconium were outstanding in improving the corrosion resistance of niobium. The most effective concentration range for zirconium appears to extend from about 10.5 through 45.7 a/o. For titanium and vanadium, the corrosion resistance continues to improve with titanium additions over the range of 9.4 through 33.8 a/o and with vanadium additions of 4.4 through $24.2 \mathrm{a} / \mathrm{o}$.

In $680 \mathrm{~F}$ water, most of the binary titanium, vanadium, and zirconium alloys, 1. the above-defined ranges, show weight changes which are comparable with or lower than those for Zircaloy-2. In $750 \mathrm{~F}$ steam, the $9.4 \mathrm{a} / 0$ titanium and $6.6,8.9$, and 12.6 a/o vanadium alloys were the only binary alloys of those tested which showed improved corrosion behavior over Zircaloy-2. These data, as well as the comparative $680 \mathrm{~F}$ weightchange data of Table 15, indicate that titanium and vanadium are more effective in improving the corrosion resistance of niobium than zirconium. 
The data of Table 15 further indicate that binary additions of cerium, chromium, iron, molybdenum, nickel, palladium, tungsten, or yttrium, over the range of 1 to 5 a/o, either have no significant beneficial effect on corrosion resistance or actually decrease it. For example, these alloys are characterized either by weight losses of similar or greater magnitude than those obtained with unalloyed niobium or by cracking or disintegration. However, the favorable results obtained with the 7.4 a/o molybdenum alloy (Alloy 154 in Table 15) indicate that some of these elements may have beneficial effects at higher concentration levels than those investigated here.

All of the ternary alloys prepared included either titanium, vanadium, or zirconium additions. As mentioned above, these elements were the most effective binary additions in improving the corrosion resistance of niobium. Consequently, it is not surprising to find that most of the ternary alloys based on the se metals also show excellent corrosion resistance.

The lowest weight gains were most consistently found for those ternary alloys containing 10 a/o or more of titanium or zirconium. The effect of the other ternary additions to these alloys is not clear since the presence of either titanium or zirconium alone (in these concentrations) is apparently sufficient to give comparably low weight changes. On the other hand, ternary combinations of vanadium and zirconium appear no more effective than binary additions of either element alone, and are probably less effective than binary additions of vanadium alone. Similarly, the $750 \mathrm{~F}$ steam data suggest that the ternary addition of molybdenum to a 10 a/o titanium binary alloy may have a detrimental effect.

On this basis, it would appear that no significant improvements in the corrosion behavior of binary titanium, vanadium, or zirconium alloys are obtained through ternary additions of aluminum, chromium, iron, molybdenum, or nickel. However, weightchange data alone are not the only important criteria in water-corrosion resistance. The character of the corrosion film formed is also of considerable importance. Thus, it is important to recognize that, of all the niobium alloys tested in $680 \mathrm{~F}$ water, only the 28.2 a/o titanium-6. 1 a/o chromium ternary alloy and the binary and ternary zirconium alloys containing 45 a/o zirconium showed adherent tarnish films. Those on the former were iridescent while those on the latter were of the type obtained on Zircaloy- 2.

Binary titanium alloys with titanium contents in the range of this ternary-alloy composition were also fairly corrosion resistant, but did not exhibit the iridescent tarnish film. The same qualification holds for the titanium-chromium alloys of lower titanium and chromium content. It would thus appear that the combination of large amounts of titanium and chromium is necessary to obtain the iridescent film. Thus, ternary modifications of binary zirconium, titanium, or vanadium alloys may have a considerably important effect. As will be discussed shortly, these modifications can most likely be expected to occur at high alloy-concentration levels through modifications in the character of the surface oxide film.

The slight powdery character of the corrosion film which formed on the other alloys which showed low weight changes may be a foreseeable deterrent to their use as cladding materials. It is well known that stainless steels also exhibit tarnish films with a thin powdery layer during corrosion in static high-temperature water. In the presence of flowing water, at velocities up to $30 \mathrm{fps}$, the corrosion rate is increased severalfold. A more serious consequence of flow is that the stainless steel corrosion product (principally $\mathrm{Fe}_{3} \mathrm{O}_{4}$ ) is transported by the coolant water and can become radioactive when 
TABLE 15. COMPARATIVE CORROSION RESIST ANCE

\begin{tabular}{|c|c|c|c|c|c|}
\hline Alloy & $\begin{array}{c}\text { Alloy Content } \\
\text { (Balance Niobium), } \\
\text { a/o }\end{array}$ & $\begin{array}{c}\text { Thermal-Neutron } \\
\text { Absorption } \\
\text { Cross Section, } \\
\text { barns per atom }\end{array}$ & $\begin{array}{l}\text { Type of } \\
\text { Niobium } \\
\text { Base }^{(a)}\end{array}$ & $\begin{array}{c}\text { Exposure Time, } \\
\text { days }\end{array}$ & $\begin{array}{l}\text { Weight Change, } \\
\text { mg per } \mathrm{dm}^{2}\end{array}$ \\
\hline-- & $100 \mathrm{Nb}$ & 1.15 & C.P. & 42 & Disintegrated \\
\hline $\mathrm{N} 44$ & $100 \mathrm{Nb}$ & 1.15 & H.P. & 84 & Disintegrated \\
\hline $\mathbf{N} 40$ & $100 \mathrm{Nb}$ & 1.15 & H.P. & 196 & -625 \\
\hline $\mathrm{N} 1$ & $100 \mathrm{Nb}$ & 1.15 & H. P. & 196 & -510 \\
\hline TP -37 & $100 \mathrm{Nb}$ & 1.15 & H.P. & 196 & -61 \\
\hline N56 & $100 \mathrm{Nb}$ & 1.15 & H.P. & 196 & -39 \\
\hline N2 & $1.1 \mathrm{ZI}$ & 1. 14 & H.P. & 140 & $-20,400$ \\
\hline N3 & $2.2 \mathrm{Zr}$ & 1.13 & H. P. & 196 & $-1,780$ \\
\hline N4 & $5 \mathrm{ZI}_{\mathrm{I}}(\mathrm{c})$ & 1. 10 & H.P. & 196 & $-1,450$ \\
\hline N5 & $10.2 \mathrm{Zr}$ & 1.05 & H.P. & 196 & -3 \\
\hline 138 & $10.5 \mathrm{Zr}$ & 1.05 & C.P. & 196 & 67 \\
\hline 139 & $26.1 \mathrm{Zr}$ & 0.90 & C.P. & 196 & 7 \\
\hline 140 & $35.7 \mathrm{Zr}$ & 0.81 & C.P. & 196 & 66 \\
\hline $\mathrm{N} 6$ & $40 \mathrm{Zr}_{\mathrm{r}}(\mathrm{c})$ & 0.76 & H.P. & 196 & 78 \\
\hline 141 & $45.7 \mathrm{Zr}$ & 0.71 & C.P. & 196 & 55 \\
\hline N8 & $65 \mathrm{Zr}_{\mathrm{r}}(\mathrm{c})$ & 0.52 & H.P. & 196 & -112 \\
\hline N9 & $75 \mathrm{Zr}(\mathrm{c})$ & 0.42 & H. P. & 196 & 128 \\
\hline $\mathrm{N} 10$ & $90 \mathrm{Zr}^{(\mathrm{c})}$ & 0.27 & H.P. & 196 & 142 \\
\hline N11 & 3. $2 \mathrm{Ti}$ & 1.30 & H. P. & 196 & -796 \\
\hline 142 & $9.4 \mathrm{Ti}$ & 1.58 & C.P. & 196 & 65 \\
\hline $\mathrm{N} 12$ & $10.5 \mathrm{Ti}$ & 1. 60 & H.P. & 196 & 76 \\
\hline 143 & $18.8 \mathrm{Ti}$ & 2.02 & C.P. & 196 & 48 \\
\hline 144 & $24.3 \mathrm{Ti}$ & 2.26 & C.P. & 196 & 52 \\
\hline $\mathrm{N} 13$ & $25 \mathrm{Ti}(\mathrm{c})$ & 2.30 & H.P. & 196 & 45 \\
\hline 145 & $30.5 \mathrm{Ti}$ & 2.58 & C.P. & 196 & 40 \\
\hline 146 & $33.8 \mathrm{Ti}$ & 2.72 & C. P. & 196 & 33 \\
\hline N16 & $1.6 \mathrm{~V}$ & 1.18 & H. P. & 196 & 107 \\
\hline 150 & $4.4 \mathrm{~V}$ & 1. 30 & C. P. & 196 & 42 \\
\hline 147 & $6.6 \mathrm{~V}$ & 1.38 & C.P. & 196 & 73 \\
\hline 148 & $8.9 \mathrm{~V}$ & 1.48 & C.P. & 196 & 59 \\
\hline 149 & $10.7 \mathrm{~V}$ & 1.54 & C. P. & 196 & 78 \\
\hline$N L-2$ & $12.6 \mathrm{~V}$ & 1. 61 & H. P. & 196 & 58 \\
\hline 158 & $13.7 \mathrm{~V}$ & 1.65 & C. $P$. & 196 & 50 \\
\hline 151 & $24.2 \mathrm{~V}$ & 2.06 & C. P. & 196 & 0 \\
\hline 163 & $1.1 \mathrm{~W}$ & 1.3 & C.P. & 196 & -260 \\
\hline 164 & $4.7 \mathrm{~W}$ & 2.0 & C. P. & 196 & -2930 \\
\hline 165 & $9.6 \mathrm{~W}$ & 2.8 & C.P. & 7 & Cracked \\
\hline 152 & $2.45 \mathrm{Mo}$ & 1. 18 & C.P. & 196 & -710 \\
\hline 153 & 5. $2 \mathrm{Mo}$ & 1. 21 & C.P. & 196 & -130 \\
\hline NL-3 & 7. $2 \mathrm{Mo}$ & 1. 25 & H. P. & 196 & $0^{(d)}$ \\
\hline 154 & 7. $4 \mathrm{Mo}$ & 1. 26 & C. P. & 196 & 62 \\
\hline N14 & $<0.02 \mathrm{Cr}$ & 1.15 & H. P. & 196 & -328 \\
\hline N15 & $0.5 \mathrm{Cr}$ & 1.16 & H.P. & 196 & -80 \\
\hline N48 & $0.5 \mathrm{Cr}$ & 1. 16 & H.P. & 196 & -495 \\
\hline
\end{tabular}


OF NIOBIUM ALLOYS IN $680 \mathrm{~F}$ WATER

\begin{tabular}{|c|c|c|c|c|c|}
\hline \multicolumn{6}{|c|}{ Corrosion Resistance } \\
\hline \multirow{3}{*}{$\begin{array}{l}\text { Compared With } \\
\text { "Best" } 100 \mathrm{Nb}(\mathrm{b})\end{array}$} & \multicolumn{5}{|c|}{ Compared With Zircaloy -2} \\
\hline & \multicolumn{2}{|c|}{ Higher Weight Change } & \multirow{2}{*}{$\begin{array}{l}\text { Equivalent, } \\
\pm 10 \text { per cent }\end{array}$} & \multicolumn{2}{|c|}{ Lower Weight Change } \\
\hline & $>20$ Per Cent & 10 to 20 Per Cent & & 10 to 20 Per Cent & $>20$ Per Cent \\
\hline - & $\mathrm{x}$ & & & & \\
\hline - & $x$ & & & & \\
\hline - & $\mathrm{x}$ & & & & \\
\hline - & $\mathrm{x}$ & & & & \\
\hline - & $\mathrm{x}$ & & & & \\
\hline 0 & $x$ & & & & \\
\hline - & $\mathrm{x}$ & & & & \\
\hline - & $x$ & & & & \\
\hline - & $\mathrm{x}$ & & & & \\
\hline+ & $\mathrm{x}$ & & & & \\
\hline+ & & & $\mathrm{x}$ & & \\
\hline+ & & & & & $\mathrm{x}$ \\
\hline+ & & & $\mathrm{x}$ & & \\
\hline+ & & $\mathrm{x}$ & & & \\
\hline+ & & & & $\mathrm{x}$ & \\
\hline+ & $x$ & & & & \\
\hline+ & $x$ & & & & \\
\hline+ & $x$ & & & & \\
\hline- & $\mathrm{x}$ & & & & \\
\hline+ & & & $\mathrm{x}$ & & \\
\hline+ & & $\mathrm{x}$ & & & \\
\hline+ & & & & & $\mathrm{x}$ \\
\hline+ & & & & $\mathrm{x}$ & \\
\hline+ & & & & & $\mathrm{x}$ \\
\hline+ & & & & & $x$ \\
\hline+ & & & & & $x$ \\
\hline+ & $\mathrm{x}$ & & & & \\
\hline+ & & & & & $\mathrm{x}$ \\
\hline+ & & $\mathrm{x}$ & & & \\
\hline+ & & & $x$ & & \\
\hline+ & $\mathrm{x}$ & & & & \\
\hline+ & & & $\mathrm{X}$ & & \\
\hline+ & & & & & $\mathrm{x}$ \\
\hline+ & & & & & $x$ \\
\hline - & $\mathrm{x}$ & & & & \\
\hline- & $x$ & & & & \\
\hline- & $x$ & & & & \\
\hline - & $x$ & & & & \\
\hline - & $x$ & & & & \\
\hline+ & $x$ & & & & \\
\hline+ & & & $x$ & & \\
\hline - & $\mathrm{x}$ & & & & \\
\hline- & $x$ & & & & \\
\hline- & $x$ & & & & \\
\hline
\end{tabular}


TABLE 15.

\begin{tabular}{|c|c|c|c|c|c|}
\hline Alloy & $\begin{array}{c}\text { Alloy Content } \\
\text { (Balance Niobıum), } \\
\mathrm{a} / \mathrm{o}\end{array}$ & $\begin{array}{c}\text { Thermal-Neutron } \\
\text { Absorption } \\
\text { Cross Section, } \\
\text { barns per atom }\end{array}$ & $\begin{array}{l}\text { Type of } \\
\text { Niobium } \\
\text { Base(a) }\end{array}$ & $\begin{array}{c}\text { Exposure Time, } \\
\text { days }\end{array}$ & $\begin{array}{c}\text { Weight Change, } \\
\text { mg per } \mathrm{dm}^{2}\end{array}$ \\
\hline $\mathrm{N} 45$ & $<0.08 \mathrm{Fe}$ & 1.15 & H. P. & 196 & -182 \\
\hline N46 & $0.3 \mathrm{Fe}$ & 1. 16 & H.P. & 112 & -1180 \\
\hline 169 & $4.9 \mathrm{Fe}$ & 1.22 & C.P. & 196 & 10 \\
\hline N47 & $10 \mathrm{Fe}^{(\mathrm{c})}$ & 1.28 & H.P. & 28 & -2000 \\
\hline $\mathrm{N} 61$ & $1 \mathrm{~N}_{1}(\mathrm{c})$ & 1.18 & H.P. & 28 & $4^{(\mathrm{d})}$ \\
\hline N62 & $2.5 \mathrm{~N}_{1}(\mathrm{c})$ & 1.23 & $\mathrm{H}, \mathrm{P}$. & 7 & Cracked \\
\hline $\mathrm{N} 63$ & $5 \mathrm{~N}_{1}(\mathrm{c})$ & 1. 32 & H. P. & 7 & Disintegrated \\
\hline N64 & $1 \mathrm{Pd}(\mathrm{c})$ & 1.21 & H.P. & 28 & -834 \\
\hline N59 & $1 Y(c)$ & 1.15 & H.P. & 56 & -1020 \\
\hline N60 & $5 Y^{(c)}$ & 1.16 & H.P. & 56 & -6420 \\
\hline N57 & $1 \mathrm{Ce}^{(c)}$ & 1. 13 & H.P. & 56 & -1180 \\
\hline$N L-10$ & $9.6 \mathrm{~T} 1-3.3 \mathrm{Cr}$ & 1.75 & H. P. & 196 & 51 \\
\hline 175 & $12 \mathrm{~T} 1-0.5 \mathrm{Cr}$ & 1. 72 & C.P. & 196 & 66 \\
\hline 176 & $20.2 \mathrm{~T}_{1}-2.1 \mathrm{Cr}$ & 2.12 & C.P. & 196 & 39 \\
\hline 177 & $28.2 \mathrm{~T}_{1}-6.1 \mathrm{Cr}$ & 2.56 & C.P. & 196 & 20 \\
\hline NL -7 & 11. $2 \mathrm{Tl}-3.2 \mathrm{Mo}$ & 1.72 & H.P. & 196 & 55 \\
\hline 172 & $12 \mathrm{~T}_{1}-4.2 \mathrm{Mo}$ & 1. 78 & C.P. & 196 & 64 \\
\hline 173 & $17.4 \mathrm{~T}_{1}-6.2 \mathrm{Mo}$ & 2.06 & C.P. & 196 & 54 \\
\hline$N L-6$ & $18.8 \mathrm{Tl}-8.7 \mathrm{Mo}$ & 2.15 & H.P. & 196 & 53 \\
\hline 174 & $23.1 \mathrm{~T} 1-7.8 \mathrm{Mo}$ & 2.35 & C.P. & 196 & 45 \\
\hline $\mathrm{N} 49$ & $2 \mathrm{~V}-2.5 \mathrm{~T}_{1}$ & 1.34 & H.P. & 196 & 88 \\
\hline 178 & $5 \mathrm{~V}-10.4 \mathrm{Tl}$ & 1.57 & C.P. & 196 & 56 \\
\hline 179 & $8.4 \mathrm{~V}-16.1 \mathrm{Ti}$ & 1.80 & C.P. & 196 & 40 \\
\hline 180 & $11 \mathrm{~V}-22.6 \mathrm{~T} 1$ & 2.05 & C. P. & 196 & 48 \\
\hline N17 & $2.3 \mathrm{Zr}-4 \mathrm{~V}$ & 1. 26 & H. P. & 196 & 60 \\
\hline NL -9 & $5.7 \mathrm{Zr}-11.4 \mathrm{~V}$ & 1. 50 & H. P. & 196 & $23^{(d)}$ \\
\hline $\mathrm{NL}-8$ & $9.9 \mathrm{Zr}-9.4 \mathrm{~V}$ & 1.39 & H. P. & 196 & $44(d)$ \\
\hline N18 & $25 \mathrm{Zr}-5 \mathrm{~V}(\mathrm{c})$ & 1. 10 & H.P. & 196 & -284 \\
\hline $\mathrm{N} 19$ & $35 \mathrm{Zr}-5 \mathrm{~V}(\mathrm{c})$ & 1.00 & H.P. & 196 & -352 \\
\hline $\mathrm{N} 20$ & $45 \mathrm{Zr}-5 \mathrm{~V}(\mathrm{c})$ & 0.90 & H. P. & 196 & 60 \\
\hline $\mathrm{N} 21$ & $10.9 \mathrm{Zr}-5.1 \mathrm{Tl}$ & 1.24 & H.P. & 196 & 61 \\
\hline $\mathrm{N} 22$ & $25 \mathrm{Zr}-5 \mathrm{~T}_{1}(\mathrm{c})$ & 1.10 & H. P. & 196 & -44 \\
\hline $\mathrm{N} 23$ & $25 \mathrm{Zr}-15 \mathrm{~T}_{1}(\mathrm{c})$ & 1. 56 & H. P. & 196 & 48 \\
\hline N24 & $25 \mathrm{Zr}-25 \mathrm{~T}_{1}(\mathrm{c})$ & 2.04 & H. P. & 196 & 48 \\
\hline $\mathrm{N} 25$ & $35 \mathrm{Zr}-5 \mathrm{~T}_{1}(\mathrm{c})$ & 1.00 & H.P. & 196 & 71 \\
\hline $\mathrm{N} 26$ & $35 \mathrm{Zr}-15 \mathrm{~T}_{1}(\mathrm{c})$ & 1.50 & H.P. & 196 & 37 \\
\hline N28 & $45 \mathrm{Zr}-5 \mathrm{~T}_{1}(\mathrm{c})$ & 0.92 & H. P. & 196 & 71 \\
\hline $\mathrm{NL}-4$ & $46.8 \mathrm{Zr}-5.1 \mathrm{~T} 1$ & 0.92 & H. P. & 196 & 92 \\
\hline $\mathrm{N} 29$ & $10 \mathrm{Zr}_{\mathrm{r}}-5 \mathrm{Mo}^{(\mathrm{c})}$ & 1. 13 & H. P. & 196 & $18^{(\mathrm{d})}$ \\
\hline N30 & $35 \mathrm{Zr}-5 \mathrm{Mo}^{(\mathrm{c})}$ & 0.88 & H. P. & 196 & 53 \\
\hline N31 & $45 \mathrm{Zr}-5 \mathrm{Mo}(\mathrm{c})$ & 0.78 & H. P. & 196 & 70 \\
\hline
\end{tabular}


(Continued)

Corrosion Resistance

\begin{tabular}{|c|c|c|c|c|c|}
\hline \multirow{3}{*}{$\begin{array}{l}\text { Compared With } \\
\text { "Best" } 100 \mathrm{Nb}(\mathrm{b})\end{array}$} & \multicolumn{5}{|c|}{ Compared With Zircaloy-2 } \\
\hline & \multicolumn{2}{|c|}{ Higher Weight Change } & \multirow{2}{*}{$\begin{array}{l}\text { Equivalent, } \\
\pm 10 \text { per cent }\end{array}$} & \multicolumn{2}{|c|}{ Lower Weight Change } \\
\hline & $>20$ Per Cent & 10 to 20 Per Cent & & 10 to 20 Per Cent & $>20$ Per Cent \\
\hline - & $X$ & & & & \\
\hline- & $x$ & & & & \\
\hline+ & & & & & $X$ \\
\hline- & $x$ & & & & \\
\hline- & $X$ & & & & \\
\hline- & $\mathrm{x}$ & & & & \\
\hline- & $x$ & & & & \\
\hline- & $X$ & & & & \\
\hline- & $X$ & & & & \\
\hline- & $x$ & & & & \\
\hline- & $x$ & & & & \\
\hline+ & & & & & $X$ \\
\hline+ & & & $X$ & & \\
\hline+ & & & & & $X$ \\
\hline+ & & & & & $x$ \\
\hline+ & & & & $x$ & \\
\hline+ & & & $X$ & & \\
\hline+ & & & & $\mathrm{X}$ & \\
\hline+ & & & & $x$ & \\
\hline+ & & & & & $X$ \\
\hline+ & $x$ & & & & \\
\hline \pm & & & & $x$ & \\
\hline+ & & & & & $X$ \\
\hline+ & & & & & $X$ \\
\hline+ & & & $\mathrm{x}$ & & \\
\hline+ & $x$ & & & & \\
\hline+ & $X$ & & & & \\
\hline - & $X$ & & & & \\
\hline - & $X$ & & & & \\
\hline+ & & & $X$ & & \\
\hline+ & & & $X$ & & \\
\hline- & $X$ & & & & \\
\hline+ & & & & & $X$ \\
\hline+ & & & & & $X$ \\
\hline+ & & & $X$ & & \\
\hline+ & & & & & $X$ \\
\hline+ & & & $X$ & & \\
\hline+ & $X$ & & & & \\
\hline+ & $X$ & & & & \\
\hline+ & & & & $X$ & \\
\hline+ & & & $X$ & & \\
\hline
\end{tabular}


TABLE 15.

\begin{tabular}{|c|c|c|c|c|c|}
\hline Alloy & $\begin{array}{c}\text { Alloy Content } \\
\text { (Balance Niobium), } \\
\text { a/o }\end{array}$ & $\begin{array}{c}\text { Thermal-Neutron } \\
\text { Absorption } \\
\text { Cross Section, } \\
\text { barns per atom }\end{array}$ & $\begin{array}{l}\text { Type of } \\
\text { Niobium } \\
\text { Base(a) }^{(a)}\end{array}$ & $\begin{array}{c}\text { Exposure Time, } \\
\text { days }\end{array}$ & $\begin{array}{l}\text { Weight Change, } \\
\text { mg per dm }\end{array}$ \\
\hline N32 & $35 \mathrm{Zr}-5 \mathrm{Al}(\mathrm{c})$ & 0.76 & H. P. & 196 & 62 \\
\hline N34 & $45 \mathrm{Zr}-5 \mathrm{Ai}(\mathrm{c})$ & 0.67 & H.P. & 196 & 60 \\
\hline N35 & $10 \mathrm{Zr}-5 \mathrm{Cr}(\mathrm{c})$ & 1. 14 & H.P. & 196 & 48 \\
\hline N37 & $45 \mathrm{Zr}-5 \mathrm{Cr}(\mathrm{c})$ & 0.93 & H.P. & 196 & 48 \\
\hline N38 & $10 \mathrm{Zr}-5 \mathrm{Fe}^{(\mathrm{c})}$ & 1. 12 & H.P. & 196 & 44 \\
\hline N50 & $2 \mathrm{~V}-2.3 \mathrm{Mo}$ & 1. 29 & H.P. & 196 & 114 \\
\hline N51 & $2.2 \mathrm{~V}-0.54 \mathrm{Fe}$ & 1. 24 & H.P. & 196 & 79 \\
\hline N53 & $1.8 \mathrm{~V}-<0.02 \mathrm{Cr}$ & 1. 19 & H.P. & 196 & 58 \\
\hline \multirow[t]{2}{*}{ N54 } & $1.8 \mathrm{~V}-0.14 \mathrm{Al}$ & 1. 19 & H.P. & 196 & 88 \\
\hline & Zircaloy -2 & 0.19 & -. & 196 & 65 \\
\hline
\end{tabular}

(a) C. P. designates commercial purity, H.P. designates high purity.

(b) Corrosion resistance, in terms of relative weight change to Sample N56; "-" designates greater weight change; "+" designates lower weight change.

(c) Nominal composition.

(d) Losing weight. 
(Continued)

Corrosion Resistance

\begin{tabular}{|c|c|c|c|c|c|}
\hline \multirow{3}{*}{$\begin{array}{l}\text { Compared With } \\
\text { "Best" } 100 \mathrm{Nb}^{(\mathrm{b})}\end{array}$} & \multicolumn{5}{|c|}{ Compared With Zircaloy -2} \\
\hline & \multicolumn{2}{|c|}{ Higher Weight Change } & \multirow{2}{*}{$\begin{array}{l}\text { Equivalent, } \\
\pm 10 \text { per cent }\end{array}$} & \multicolumn{2}{|c|}{ Lower Weight Change } \\
\hline & $>20$ Per Cent & 10 to 20 Per Cent & & 10 to 20 Per Cent & $>20$ Per Cent \\
\hline+ & & & $\mathrm{x}$ & & \\
\hline+ & & & $x$ & & \\
\hline+ & & & & & $\mathrm{X}$ \\
\hline+ & & & & & $x$ \\
\hline+ & & & & & $\mathrm{X}$ \\
\hline+ & $\mathrm{X}$ & & & & \\
\hline+ & $\mathrm{x}$ & & & & \\
\hline+ & & & $\mathrm{x}$ & & \\
\hline+ & $\mathrm{x}$ & & & & \\
\hline+ & & & $\mathrm{x}$ & & \\
\hline
\end{tabular}


TABLE 16. COMPARATIVE CORROSION RESISTANCE OF NIOBIUM ALLOYS IN 750 F STEAM

\begin{tabular}{|c|c|c|c|c|c|c|c|c|}
\hline \multirow[b]{3}{*}{ Alloy } & \multirow[b]{3}{*}{$\begin{array}{c}\begin{array}{c}\text { Alloy Content } \\
\text { (Balance Niobium), } \\
\text { a/o }\end{array} \\
\end{array}$} & \multirow{3}{*}{$\begin{array}{c}\text { Thermal-Neutron- } \\
\text { Absorption } \\
\text { Cross Section, } \\
\text { barns per atom }\end{array}$} & \multirow[b]{3}{*}{$\begin{array}{c}\text { Type of } \\
\text { Niobium } \\
\text { Base(a) }\end{array}$} & \multirow[b]{3}{*}{$\begin{array}{c}\text { Exposure } \\
\text { Time, } \\
\text { days }\end{array}$} & \multirow[b]{3}{*}{$\begin{array}{c}\text { Weight } \\
\text { Change, } \\
\text { mg per dm² }\end{array}$} & \multicolumn{3}{|c|}{ Corrosion Resistance } \\
\hline & & & & & & \multirow[b]{2}{*}{$\begin{array}{l}\text { Compared With } \\
\text { "Best"(b) } 100 \mathrm{Nb}\end{array}$} & \multicolumn{2}{|c|}{ Compared With Zircaloy-2 } \\
\hline & & & & & & & $\begin{array}{l}\text { Higher Weight } \\
\text { Change } \\
\text { (>20 Per Cent) }\end{array}$ & $\begin{array}{c}\text { Lower Weight } \\
\text { Change } \\
(>20 \text { Per Cent) }\end{array}$ \\
\hline-- & $100 \mathrm{Nb}$ & 1.15 & C.P. & 28 & Disintegrated & - & $\mathrm{x}$ & \\
\hline TP -37 & $100 \mathrm{Nb}$ & 1. 15 & H. P. & 210 & $-4,570$ & 0 & $\mathrm{x}$ & \\
\hline 138 & $10.5 \mathrm{Zr}$ & 1.05 & C.P. & 210 & $-3,970$ & + & $\mathrm{x}$ & \\
\hline 142 & $9.4 \mathrm{Ti}$ & 1. 58 & C.P. & 210 & 119 & + & & $x$ \\
\hline 150 & $4.4 \mathrm{~V}$ & 1.30 & C. P. & 210 & $-2,400$ & + & $x$ & \\
\hline 147 & $6.6 \mathrm{~V}$ & 1.38 & C. P. & 210 & 127 & + & & $x$ \\
\hline 148 & $8.9 \mathrm{~V}$ & 1. 48 & C.P. & 210 & 118 & + & & $x$ \\
\hline NL -2 & $12.6 \mathrm{~V}$ & 1.61 & H.P. & 210 & 89 & + & & $x$ \\
\hline 152 & 2. $45 \mathrm{Mo}$ & 1.18 & C.P. & 98 & Disintegrated & - & $\mathrm{x}$ & \\
\hline 153 & 5. $2 \mathrm{Mo}$ & 1. 21 & C.P. & 210 & $-18,450$ & - & $\mathrm{x}$ & \\
\hline NL -3 & $7.2 \mathrm{Mo}$ & 1. 25 & H.P. & 70 & Cracked & - & $\mathrm{x}$ & \\
\hline 169 & $4.9 \mathrm{Fe}$ & 1. 22 & C.P. & 98 & Disintegrated & - & $\mathrm{x}$ & \\
\hline 163 & $1.1 \mathrm{~W}$ & 1.3 & C.P. & 210 & $-6,420$ & - & $\mathrm{x}$ & \\
\hline$N L-10$ & $9.6 \mathrm{Ti}-3.3 \mathrm{Cr}$ & 1.75 & H.P. & 182 & -499 & + & $\mathrm{x}$ & \\
\hline NL -7 & 11. $2 \mathrm{Ti}-3.2 \mathrm{Mo}$ & 1. 72 & H.P. & 266 & $36^{(c)}$ & + & $x$ & \\
\hline NL- 6 & $18.8 \mathrm{Ti}-8.7 \mathrm{Mo}$ & 2.15 & H. P. & 266 & $53^{(c)}$ & + & $\mathrm{x}$ & \\
\hline NL -9 & $5.7 \mathrm{Zr}-11.4 \mathrm{~V}$ & 1. 50 & H.P. & 182 & -215 & + & $\mathrm{x}$ & \\
\hline NL-8 & $9.9 \mathrm{Zr}-9.4 \mathrm{~V}$ & 1. 39 & H.P. & 182 & -587 & + & $x$ & \\
\hline NL -4 & $46.8 \mathrm{Zr}-5.1 \mathrm{Ti}$ & 0.92 & H.P. & 266 & 251 & + & & $\mathrm{x}$ \\
\hline \multirow[t]{3}{*}{--} & Zircaloy -2 & 0.19 & -- & 182 & 220 & + & & \\
\hline & & & - & 210 & 225 & + & & \\
\hline & & & - & 266 & 327 & + & & \\
\hline
\end{tabular}

(b) Corrosion resistance, in terms of weight change relative to sample TP-37; "-" designates greater weight change; "+" designates lower weight change.

(c) Losing weight. 
in the vicinity of the reactor core. On the other hand, the corrosion rates of zirconium alloys, which possess adherent tarnish films, are unaffected by flow velocity. Only very small amounts of radioactive zirconium are detected in coolant waters. Similar behavior might be expected with niobium alloys. The corrosion behavior of those alloys with adherent films may be unaffected by flow velocity. On the other hand corrosion rates and product transport of those with less adherent films may increase with increasing flow velocity.

Based on the information obtained to date, it is not yet known whether hydrogen absorption in niobium during corrosion poses a problem as it does with zirconium alloys. Results indicate that hydrogen absorption is low in the more corrosion-resistant alloys and is high only in those alloys which exhibit high corrosion rates.

Oxygen contamination of niobium alloys also appears to be related to corrosion resistance. In general, high oxygen-diffusion coefficients were obtained with less resistant alloys. However, contamination of niobium alloys from oxygen in the oxide film does not appear to be a serious problem. Depth of contamination after 196 days' exposure to $680 \mathrm{~F}$ water was found to be less than 1 mil for the more corrosion-resistant alloys and less than 5 mils for less resistant alloys.

\section{Theoretical Aspects}

It is of interest to compare the observed effects of various binary alloy additions on the water corrosion resistance of niobium in the light of the principles which were developed (3) to explain alloying effects on the hot-air oxidation of niobium. In the case of water corrosion, the assumption is made that, as in hot air, the reaction rate depends primarily on the nature of the oxidation product formed at the niobium: water interface. Accordingly, the effects of alloying additions may be compared by the manner in which they influence the surface oxidation product formed on niobium in water. As shown earlier, the surface-oxidation product formed on niobium in $680 \mathrm{~F}$ water is the T-type $\mathrm{Nb}_{2} \mathrm{O}_{5}$, the same oxide which is predominantly formed on the surface of niobium heated in air at temperatures through $1470 \mathrm{~F}$.

In the earlier Battelle work(3), three principles of alloying behavior were shown to be effective in governing the hot-air oxidation behavior of niobium. These are briefly summarized below:

Valence Effect: Niobium oxide is a semiconductor of the metal-excess or anion-deficit type. Accordingly, the addition of metal ions of higher valence than niobium decreases the number of interstitial metal ions or oxygen-ion vacancies in order to maintain electrical neutrality in the oxide. Since these defects are the means by which diffusion occurs through the scale, reducing their number decreases ionic-diffusion rates and thus the oxidation rate of the alloy. Adding metal ions of lower valence has the opposite effect, increasing the number of defects and increasing the alloy oxidation rate.

Size Effect: Metals of smaller ionic radii than niobium enter the oxide scale substitutionally where, because of their smaller size, they tend to lower the unfavorably high oxide:metal volume ratio of niobium. As a result, the mechanical stability of the scale is increased and it becomes more protective, i. e., the alloy oxidation rate is decreased. Conversely, metals of larger 
ionic radii tend to decrease scale stability and increase oxidation by further increasing the oxide: metal volume ratio.

New-Scale Effect: In the range beyond the solubility limit for addition metal ions in the niobium oxide, new oxides must form. These may consist of mixed oxides or pure oxides of the alloying addition. Generally, if the new oxide(s) have improved thermodynamic, mechanical, or physical properties over that of the niobium oxide, improved oxidation resistance may result.

As implied above, valence and size effects are expected to predominate at low alloy levels (less than about 15 a/o) while new-scale effects can be expected at higher alloy levels.

The valences, ionic sizes, and oxide characteristics of each of the binary additions studied in water corrosion testing are listed in Table 17. Table 18 summarizes the anticipated and observed effects of these additions on the water corrosion behavior of niobium, as suming oxidation to be the primary corrosion mechanism.

Most of the binary additions were confined to low alloy ranges. Here, as indicated in Table 18, the size effect appears to overwhelmingly predominate the valence effect. Thus, five of six binary additions anticipated to improve the corrosion resistance of niobium through size effects actually do so. Of these, vanadium, which has the smallest ionic radius, appears most effective (on an equivalent atomic per cent addition basis). On the other hand, chromium and tungsten which should show increasingly beneficial effects actually did not. In these instances, it appears possible that larger additions of these metals may be required than were actually used in the present study.

Because of the wide range in $680 \mathrm{~F}$ corrosion rates observed for the various unalloyed niobium samples, it is not possible to accurately compare the behavior of the less-corrosion-resistant alloys. Nevertheless, the cerium, palladium, and yttrium alloys were among the least-corrosion-resistant materials tested, a behavior which might be explainable on the basis of their unfavorably large ionic radii.

The effectiveness of zirconium additions in improving the corrosion resistance of niobium can only be explained by the new scale effect. This thesis is supported by the $\mathrm{X}$-ray evidence which showed that a double oxide, $6 \mathrm{ZrO}_{2} \cdot \mathrm{Nb}_{2} \mathrm{O}_{5}$, was formed on the 45.7 a/o zirconium alloy exposed for 42 days in $680 \mathrm{~F}$ water.

Comparison of the hot-water corrosion and air oxidation behavior of niobium alloys shows several strong points of similarity.

First, in water corrosion as in air oxidation, size effects predominate over valence effects at low alloy concentrations.

Second, the most effective additions in improving air oxidation resistance were found to be those capable of forming new, stable, diffusion-resistant oxides. Again, in the water-corrosion work, the best combinations of low weight gain and adherent tarnish films were found with high-zirconium alloys and the 28.2 a/o titanium- 6.1 a/o chromium alloy, both of which form new scales. 
TABLE 17. VALENCE, IONIC SIZE, AND OXIDE CHARACTERISTICS OF ELEMENTS ADDED TO NIOBIUM(7,8,9)

\begin{tabular}{lcccc}
\hline \multicolumn{1}{c}{ Element } & Valence & $\begin{array}{c}\text { Goldschmidt } \\
\text { Ionic Radius }\end{array}$ & $\begin{array}{c}\text { Negative Free Energy of } \\
\text { Formation of Oxide at 620 } \mathrm{F}, \\
\text { kcal per g-atom of oxygen }\end{array}$ & $\begin{array}{c}\text { Oxide:Metal } \\
\text { Volume Ratio }\end{array}$ \\
\hline Cerium & 4 & 0.94 & 107 & 1.16 \\
Yttrium & 3 & 0.92 & 125 & 1.39 \\
Palladium & 2 & 0.80 & 10.7 & 1.65 \\
Zirconium & 4 & 0.79 & 117 & 1.56 \\
Nickel & 2 & 0.69 & 43.9 & 1.65 \\
& & & & 2.69 \\
Niobium & 5 & 0.69 & 78.2 & 1.73 \\
Titanium & 4 & 0.68 & 99.6 & 2.14 \\
Iron & 3 & 0.64 & 52.8 & 2.07 \\
Chromium & 3 & 0.63 & 77.9 & 3.24 \\
Molybdenum & 6 & 0.62 & 47.9 & 3.25 \\
Tungsten & 6 & 0.62 & 54.7 & 3.19 \\
Vanadium & 5 & 0.59 & 62.1 & \\
\hline \hline
\end{tabular}

TABLE 18. EFFECTS OF BINARY ALLOY ADDITIONS ON THE $680 \mathrm{~F}$ WATER-CORROSION BEHAVIOR OF NIOBIUM

\begin{tabular}{|c|c|c|c|c|}
\hline \multirow[b]{2}{*}{ Mechanism } & \multicolumn{4}{|c|}{ Effect of Additions on Corrosion Behavior } \\
\hline & $\begin{array}{l}\text { Decreasing Corrosion Resistance } \\
\text { (Increasing Weight Changes) }\end{array}$ & $\begin{array}{l}\text { Negligible } \\
\text { Effect }\end{array}$ & $\begin{array}{l}\text { Negligible Effect } \\
\text { or Slightly } \\
\text { Increased Corro- } \\
\text { sion Resistance }\end{array}$ & $\begin{array}{l}\text { Increasing Corrosion } \\
\text { Resistance (Decreasing } \\
\text { Weight Changes) }\end{array}$ \\
\hline \multicolumn{5}{|c|}{ Anticipated Behavior } \\
\hline Valence effect & $\begin{array}{l}\text { Nickel, iron, cerium, palladium, chromium, } \\
\text { titanium, yttrium, zirconium }\end{array}$ & Vanadium & & Molybdenum, tungsten \\
\hline Size effect & $\begin{array}{l}\text { Cerium, yttrium, palladium, zirconium, } \\
\text { nickel }\end{array}$ & & & $\begin{array}{l}\text { Titanium, iron, chromium, } \\
\text { molybdenum, tungsten, } \\
\text { vanadium }\end{array}$ \\
\hline New scale effect & & & & Titanium $^{(a)}$, zirconium $(a)$ \\
\hline \multicolumn{5}{|c|}{ Generally Observed Behavior } \\
\hline & $\begin{array}{l}\text { Yttrium, chromium, cerium, tungsten, } \\
\text { nickel, palladium }\end{array}$ & & Iron, molybdenum & $\begin{array}{l}\text { Zirconium, titanium, } \\
\text { vanadium }\end{array}$ \\
\hline
\end{tabular}

(a) Placement based on high free energy of formation of oxide and more favorable oxide:metal volume ratio. 
Finally, the additions (i.e., titaniurn, vanadium, and zirconium) found most effective in improving the corrosion resistance of niobium to water and steam were also among the most effective additions in improving the hot-air oxidation resistance of niobium.

These observations lend strong support to the beliefs that oxidation is the primary reaction involved in both hot water and air, and that the mechanism for forming more protective oxides, through alloying, against both media is basically the same.

$\underline{\text { Hot Hardness }}$

The hardnesses of most of the fabricable alloys were determined, after vacuum annealing, at temperatures through $1650 \mathrm{~F}$. These data are given in Table 19 and plotted as a function of temperature in Figures 9 to 16.

Hardness data were obtained for unalloyed niobium in two conditions: (1) asreceived electron-beam-melted ingot, and (2) the same material after melting, cold rolling, and vacuum annealing. The curves for both materials were quite similar, as shown in Figure 9. Thus, the hardness of unalloyed niobium holds fairly constant at temperatures to $600 \mathrm{~F}$ after which it decreases fairly rapidly with increasing temperatures. Due to its higher interstitial content from contamination in processing, the sheet niobium maintained a higher hardness at all temperatures. Also, above $600 \mathrm{~F}$, the hardness of sheet decreased less rapidly with increasing temperature than that for the higher purity ingot material.

Generally, the hardness curves for most of the alloys were similar. The general behavior was for hardness to decrease progressively at a uniform rate with increasing temperature to $1650 \mathrm{~F}$. None of the alloy curves showed sharp breaks like those exhibited by the unalloyed niobium at $600 \mathrm{~F}$.

The most notable exception to this general rule occurred for the binary and ternary alloys containing 1.1 through 10 a/o zirconium. As shown in Figure 9, the hardnesses of binary alloys containing 10 a/o zirconium and less tended to increase at temperatures above $1200 \mathrm{~F}$. Also, as illustrated in Figures 15 and 16, the same behavior occurs in ternary alloys containing 2.3 through 10 a/o zirconium. It is concluded that zirconium increases the hardness during testing by gettering traces of oxygen from the test atmosphere to form a thin, hard subsurface oxide dispersion. The magnitude of this effect increases with temperatures above $1200 \mathrm{~F}$. Also, the hardness-change data in Table 19 and the curves in Figure 17 indicate maximum susceptibility to hardness contamination occurs for zirconium contents of 5 to $10 \mathrm{a} / \mathrm{o}$.

Binary titanium additions of 10 to 25 a/o appear to have a similar effect on niobium, though not nearly to the same degree as zirconium. Most of the other alloys show no evidence of this behavior.

The specific effects of binary molybdenum, titanium, vanadium, and zirconium additions on the hot hardness of niobium are more apparent from comparisons of Figures 17, 18, and 19 which show hardness plotted as a function of alloy composition. Initial additions of zirconium, vanadium, and molybdenum, in amounts through 30 a/o, $5 \mathrm{a} / \mathrm{o}$, and $2.5 \mathrm{a} / \mathrm{o}$, respectively, result in approximately linear increases in the hot 
TABLE 19. HOT HARDNESS OF SELECTED NIOBIUM-BASE ALLOYS

\begin{tabular}{|c|c|c|c|c|c|c|c|c|c|c|}
\hline \multirow[b]{2}{*}{ Alloy } & \multirow{2}{*}{$\begin{array}{c}\text { Alloy Content } \\
\text { (Balance Nioblum) }^{(a)} \text {, } \\
a / 0\end{array}$} & \multirow{2}{*}{$\begin{array}{l}\text { Type of } \\
\text { Niobium } \\
\text { Base }^{(b)}\end{array}$} & \multicolumn{7}{|c|}{ Hardness, VHN, at Temperature, F } & \multirow{2}{*}{$\begin{array}{c}\text { Hardness } \\
\text { Change }(\mathrm{d}) \\
\text { VHN }\end{array}$} \\
\hline & & & 75 & 600 & 900 & 1200 & 1400 & 1650 & $75(c)$ & \\
\hline-- & $100 \mathrm{Nb}$ & H.P. (e) & 81 & 78 & 56 & 37 & 26 & 21 & 82 & 1 \\
\hline N40 & $100 \mathrm{Nb}$ & H.P. $(f)$ & 97 & 95 & 74 & 65 & 54 & 46 & 93 & -4 \\
\hline N2 & $1.1 \mathrm{Zr}$ & H.P. & 108 & 75 & 71 & 75 & 87 & 84 & 123 & 15 \\
\hline N3 & $2.2 \mathrm{Zr}$ & H.P. & 130 & 116 & 87 & 84 & 100 & 99 & 126 & -4 \\
\hline $\mathrm{N} 4$ & $5 \mathrm{Zr}(\mathrm{g})$ & H.P. & 152 & 101 & 97 & 99 & 109 & 184 & 179 & 27 \\
\hline N5 & $10.2 \mathrm{ZI}$ & H.P. & 187 & 142 & 133 & 133 & 158 & 267 & 238 & 51 \\
\hline 138 & $10.5 \mathrm{Zr}$ & C.P. & 197 & 143 & 145 & 150 & 152 & 175 & 211 & 14 \\
\hline 139 & $26.1 \mathrm{Zr}$ & $C \mathrm{P}$ & 267 & 235 & 229 & $23 \epsilon$ & 222 & 181 & 279 & 12 \\
\hline 140 & $35.7 \mathrm{Zr}$ & C. P & 297 & 254 & 248 & 244 & 231 & 160 & 298 & 1 \\
\hline 141 & $45.7 \mathrm{Zr}$ & C.P. & 294 & 245 & 233 & 233 & 182 & 148 & 296 & 2 \\
\hline N16 & $1.6 \mathrm{~V}$ & H.P. & 103 & 67 & 65 & 66 & 63 & 58 & 114 & 11 \\
\hline 150 & $4.4 \mathrm{~V}$ & C.P. & 147 & 132 & 119 & 116 & 118 & 116 & 156 & 9 \\
\hline 148 & $8.9 \mathrm{~V}$ & C.P. & 191 & 150 & 144 & 134 & 146 & 147 & 200 & 9 \\
\hline 149 & $10.7 \mathrm{~V}$ & C.P. & 211 & 155 & 153 & 144 & 147 & 147 & 222 & 11 \\
\hline NL -2 & $12.6 \mathrm{~V}$ & H. P. & 246 & 164 & 155 & 153 & 153 & 149 & 259 & 13 \\
\hline 158 & $13 \mathrm{~V}$ & C.P. & 287 & 213 & 205 & 205 & 209 & 195 & 290 & 3 \\
\hline 151 & $24.2 \mathrm{~V}$ & C.P. & 334 & 258 & 242 & 241 & 241 & 212 & 341 & 7 \\
\hline N11 & $3,2 \mathrm{Tl}_{1}$ & H.P. & 97 & 52 & 49 & 45 & 42 & 41 & 109 & 12 \\
\hline 142 & $9.4 \mathrm{Tl}$ & C.P. & 133 & 77 & 74 & 75 & 67 & 74 & 143 & 10 \\
\hline $\mathrm{N} 12$ & $10.5 \mathrm{~T}_{1}$ & H.P. & 121 & 69 & 63 & 58 & 57 & 66 & 141 & 20 \\
\hline 143 & $18.8 \mathrm{Tl}_{1}$ & C.P. & 151 & 90 & 86 & 78 & 73 & 75 & 168 & 17 \\
\hline 144 & $24.3 \mathrm{Tl}_{1}$ & C.P. & 157 & 102 & 99 & 87 & 87 & 87 & 179 & 22 \\
\hline $\mathrm{N} 13$ & $25 \mathrm{~T}_{1}(\mathrm{~g})$ & H.P. & 152 & 84 & 75 & 68 & 67 & 77 & 194 & 42 \\
\hline 145 & $30.5 \mathrm{~T}_{1}$ & C.P. & 165 & 109 & 97 & 88 & 82 & 79 & 200 & 35 \\
\hline 146 & $33.8 \mathrm{~T}_{1}$ & C.P. & 177 & 114 & 103 & 89 & 81 & 76 & 221 & 53 \\
\hline 152 & 2. $45 \mathrm{Mo}$ & C.P. & 134 & 102 & 108 & 95 & 95 & 87 & 142 & 8 \\
\hline 153 & $5.2 \mathrm{Mo}$ & C.P. & 154 & 100 & 103 & 92 & 94 & 89 & 165 & 11 \\
\hline NL -3 & $7.2 \mathrm{Mo}$ & H. P. & 199 & 133 & 133 & 116 & 104 & 89 & 187 & -12 \\
\hline 154 & $7.4 \mathrm{Mo}$ & C.P. & 180 & 120 & 117 & 108 & 108 & 114 & 186 & 6 \\
\hline N45 & $<0.08 \mathrm{Fe}$ & H.P. & 98 & 72 & 76 & 60 & 60 & 52 & 97 & -1 \\
\hline N46 & $0.3 \mathrm{Fe}$ & H.P. & 106 & 123 & 95 & 92 & 89 & 71 & 110 & 4 \\
\hline 169 & $4.9 \mathrm{Fe}$ & C.P. & 143 & 109 & 109 & 97 & 96 & 84 & 141 & -2 \\
\hline N47 & $10 \mathrm{Fe}^{(\mathrm{g})}$ & H.P. & 251 & 182 & 187 & 182 & 172 & 119 & 235 & -16 \\
\hline 163 & $1.1 \mathrm{~W}$ & C.P. & 128 & 96 & 97 & 81 & 78 & 77 & 130 & 2 \\
\hline 164 & $4.7 \mathrm{~W}$ & C.P. & 178 & 137 & 145 & 117 & 108 & 103 & 174 & -4 \\
\hline N48 & $0.5 \mathrm{Cr}$ & H.P. & 120 & 82 & 78 & 77 & 77 & 64 & 123 & 3 \\
\hline 357 & $1 \mathrm{Ce}^{(g)}$ & H.P. & 64 & 50 & 53 & 40 & 32 & 27 & 62 & -2 \\
\hline$\therefore 60$ & $5 Y(g)$ & H.P. & 102 & 91 & 79 & 82 & 75 & 63 & 96 & -6 \\
\hline$\therefore 64$ & $1 \mathrm{Pd}(\mathrm{g})$ & H. P. & 107 & 77 & 77 & 63 & 62 & 51 & 102 & -5 \\
\hline
\end{tabular}


TABLE 19. (Contınued)

\begin{tabular}{|c|c|c|c|c|c|c|c|c|c|c|}
\hline \multirow[b]{2}{*}{ Alloy } & \multirow{2}{*}{$\begin{array}{c}\text { Alloy Content } \\
\text { (Balance Nrobrum) }^{(a)} \text {, } \\
a / o\end{array}$} & \multirow{2}{*}{$\begin{array}{c}\text { Type of } \\
\text { Niobıum } \\
\text { Base }^{(b)}\end{array}$} & \multicolumn{7}{|c|}{ Hardness, VHN, at Temperature, $\mathbf{F}$} & \multirow{2}{*}{$\begin{array}{c}\text { Hardness } \\
\text { Change(d), } \\
\text { VHN }\end{array}$} \\
\hline & & & 75 & 600 & 900 & 1200 & 1400 & 1650 & $75(c)$ & \\
\hline N49 & $2 \mathrm{~V}-2.5 \mathrm{Tl}$ & H.P. & 119 & 75 & 66 & 68 & 71 & 69 & 129 & 10 \\
\hline N50 & $2 \mathrm{~V}-2.3 \mathrm{Mo}$ & H. P. & 134 & 83 & 77 & 71 & 69 & 66 & 134 & 0 \\
\hline N51 & $2.2 \mathrm{~V}-0.54 \mathrm{Fe}$ & H.P. & 143 & 104 & 101 & 103 & 104 & 85 & 149 & 6 \\
\hline N52 & $2.2 \mathrm{~V}-0.87 \mathrm{NI}$ & H.P. & 168 & 139 & 135 & 128 & 124 & 94 & 171 & 3 \\
\hline N53 & $1.8 \mathrm{~V}-<0.02 \mathrm{Cr}$ & H.P. & 112 & 80 & 65 & 66 & 65 & 61 & 111 & -1 \\
\hline N54 & $1.8 \mathrm{~V}-0.14 \mathrm{Al}$ & H.P. & 104 & 73 & 65 & 63 & 69 & 58 & 112 & 8 \\
\hline N65 & $5 \mathrm{~V}-2.5 \mathrm{~T}_{1}(\mathrm{~d})$ & H. P. & 146 & 104 & 98 & 97 & 97 & 82 & 155 & 9 \\
\hline N68 & $5 \mathrm{~V}-2.5 \mathrm{Cr}^{(\mathrm{d})}$ & H.P. & 152 & 120 & 115 & 113 & 108 & 94 & 162 & 10 \\
\hline N70 & $5 \mathrm{~V}-2.5 \mathrm{Al}(\mathrm{d})$ & H. P. & 146 & 101 & 93 & 96 & 95 & 85 & 150 & 4 \\
\hline N55 & $2.5 \mathrm{~V}-2.5 \mathrm{Zr}(\mathrm{g})$ & H.P. & 141 & 114 & 103 & 100 & 113 & 115 & 144 & 3 \\
\hline N17 & $4.0 \mathrm{~V}-2.3 \mathrm{Zr}$ & H. P. & 159 & 117 & 115 & 106 & 119 & 145 & 179 & 20 \\
\hline NL -8 & $9.4 \mathrm{~V}-9.9 \mathrm{Zr}$ & H.P. & 277 & 212 & 194 & 186 & 185 & 212 & 291 & 14 \\
\hline NL -9 & $11.4 \mathrm{~V}-5.7 \mathrm{Zr}$ & H.P. & 275 & 188 & 181 & 186 & 194 & 245 & 293 & 18 \\
\hline $\mathrm{N} 21$ & $10.9 \mathrm{Z}_{\mathrm{I}}-5.1 \mathrm{Tl}_{1}$ & H.P. & 207 & 135 & 130 & 135 & 151 & 223 & 239 & 32 \\
\hline $\mathrm{N} 29$ & $10 \mathrm{Zr}-5 \mathrm{Mdg})$ & H.P. & 238 & 146 & 148 & 152 & 178 & 246 & 268 & 30 \\
\hline N35 & $10 \mathrm{Zr}_{\mathrm{r}}-5 \mathrm{Cr}(\mathrm{g})$ & H.P. & 208 & 173 & 169 & 166 & 169 & 221 & 236 & 28 \\
\hline N38 & $10 \mathrm{Zr}^{-5 \mathrm{Fe}}(\mathrm{g})$ & H.P. & 322 & 237 & 247 & 237 & 249 & 168 & 338 & 16 \\
\hline NL -4 & $46.8 \mathrm{Zr}-5.1 \mathrm{Tl}_{\mathrm{I}}$ & H.P. & 282 & 199 & 200 & 201 & 186 & 153 & 305 & 23 \\
\hline $\mathrm{NL}-7$ & $11.2 \mathrm{~T}_{1}-3.2 \mathrm{Mo}$ & H.P. & 178 & 107 & 87 & 80 & 79 & 87 & 189 & 11 \\
\hline NL -10 & $9.6 \mathrm{~T} 1-3.3 \mathrm{Cr}$ & H.P. & 239 & 158 & 148 & 153 & 150 & 146 & 246 & 7 \\
\hline
\end{tabular}

(a) By chemical analysis unless otherwise indicated.

(b) H. P. designates high-purity electron-beam-melted, C.P. designates commercial sintered.

(c) Hardness measured after heating samples to $1650 \mathrm{~F}$ in vacuum.

(d) Change in room-temperature hardness after heating to $1650 \mathrm{~F}$.

(e) Sample taken directly from electron-beam-melted Ingot 405-599-P37.

(f) Same material as (e) after inert-electrode arc melting, cold rolling, and vacuum annealing.

(g) Nominal compositions. 


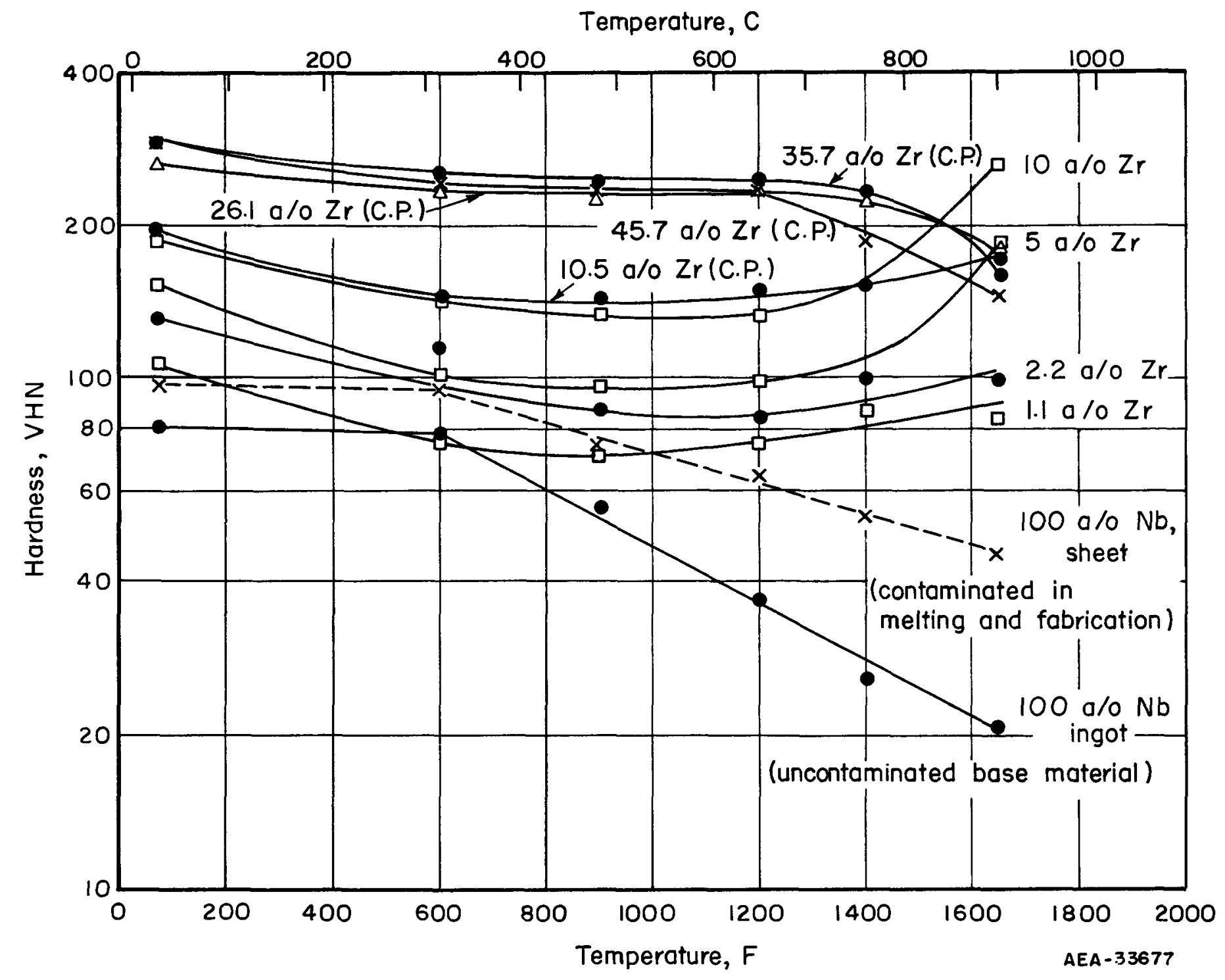

FIGURE 9. HOT HARDNESS OF NIOBIUM-ZIR CONIUM ALLOYS 


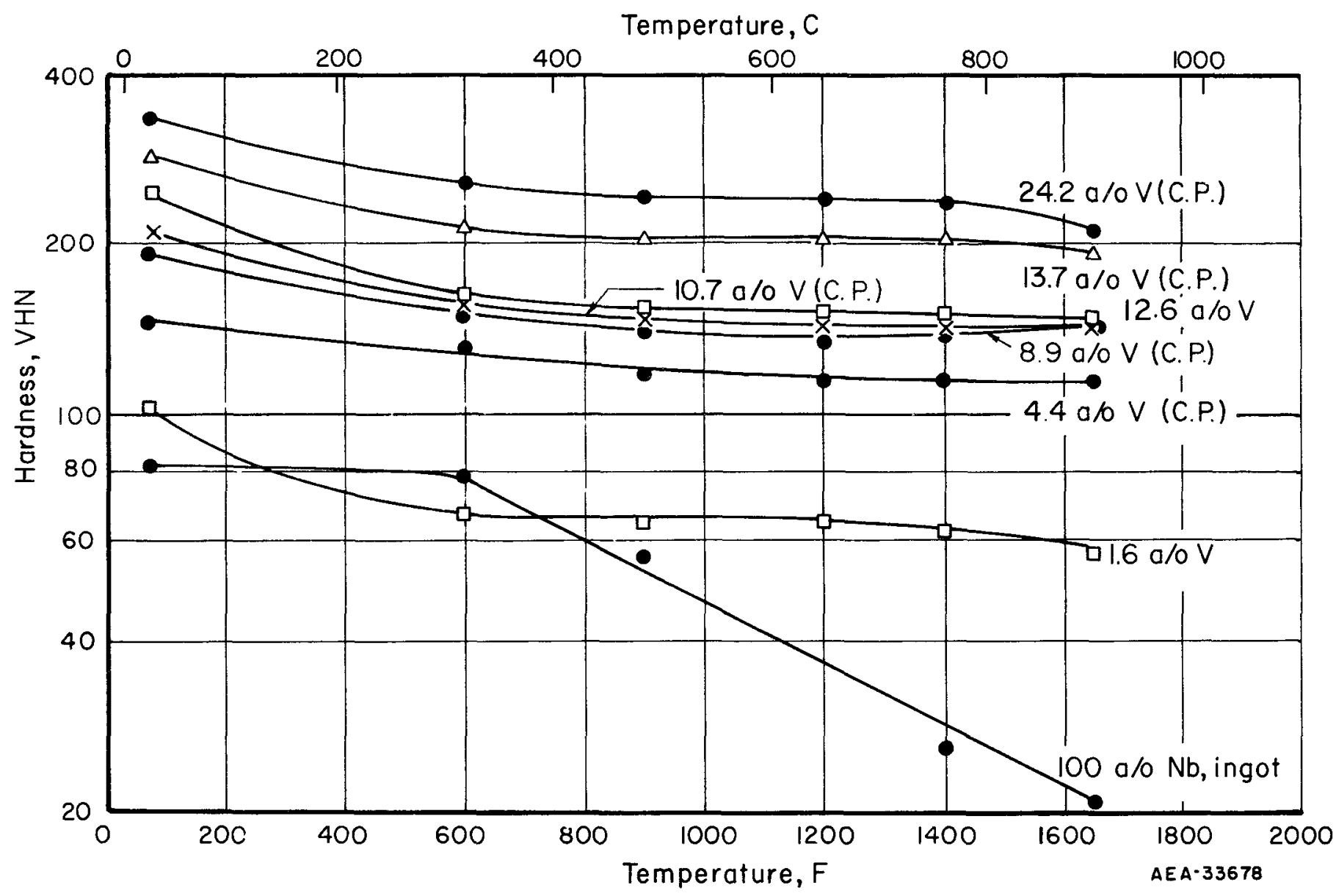

FIGURE 10. HOT HARDNESS OF NIOBIUM-VANADIUM ALLOYS 


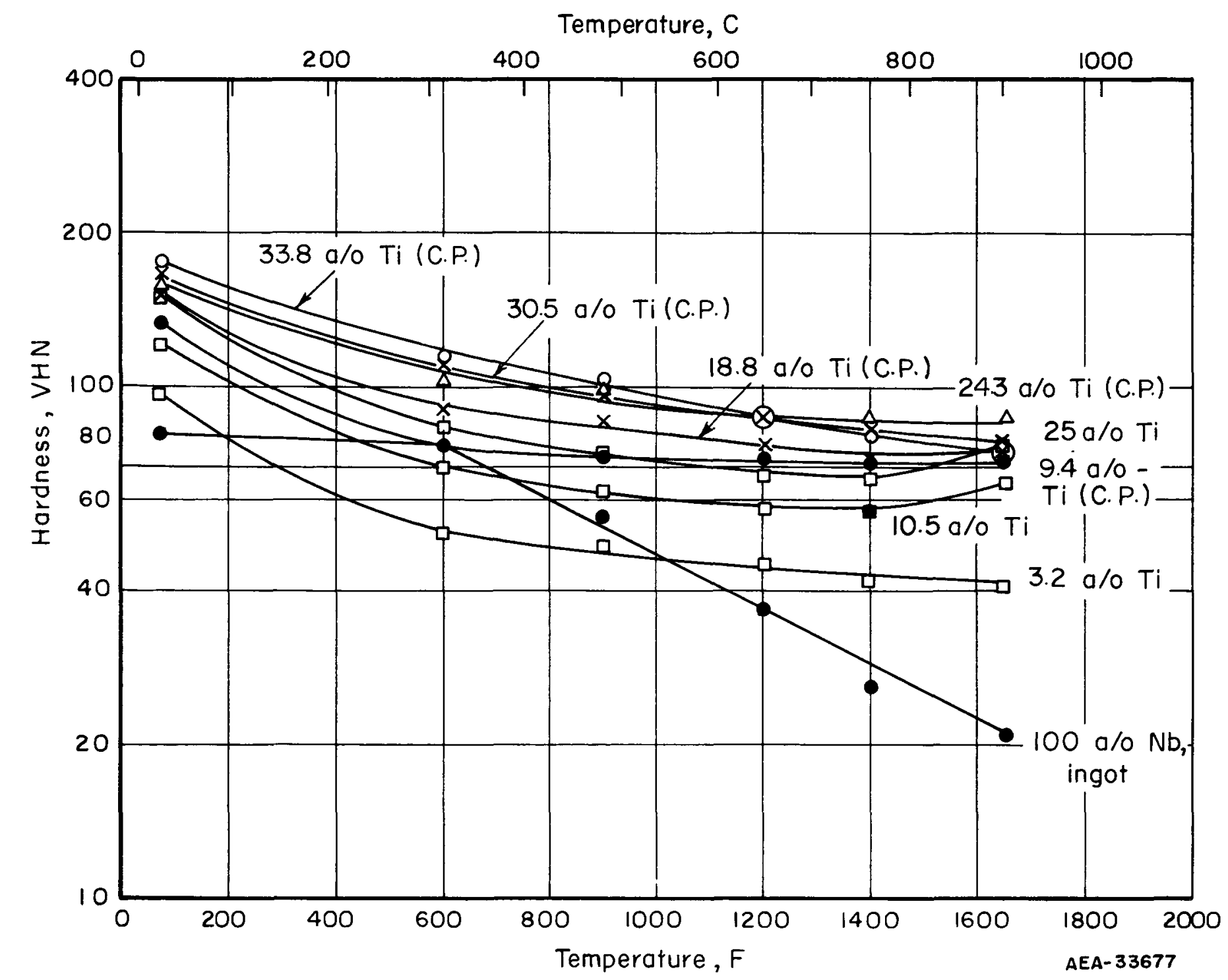

FIGURE 11. HOT HARDNESS OF NIOBIUM-TITANIUM ALLOYS 
Temperature, $\mathrm{C}$

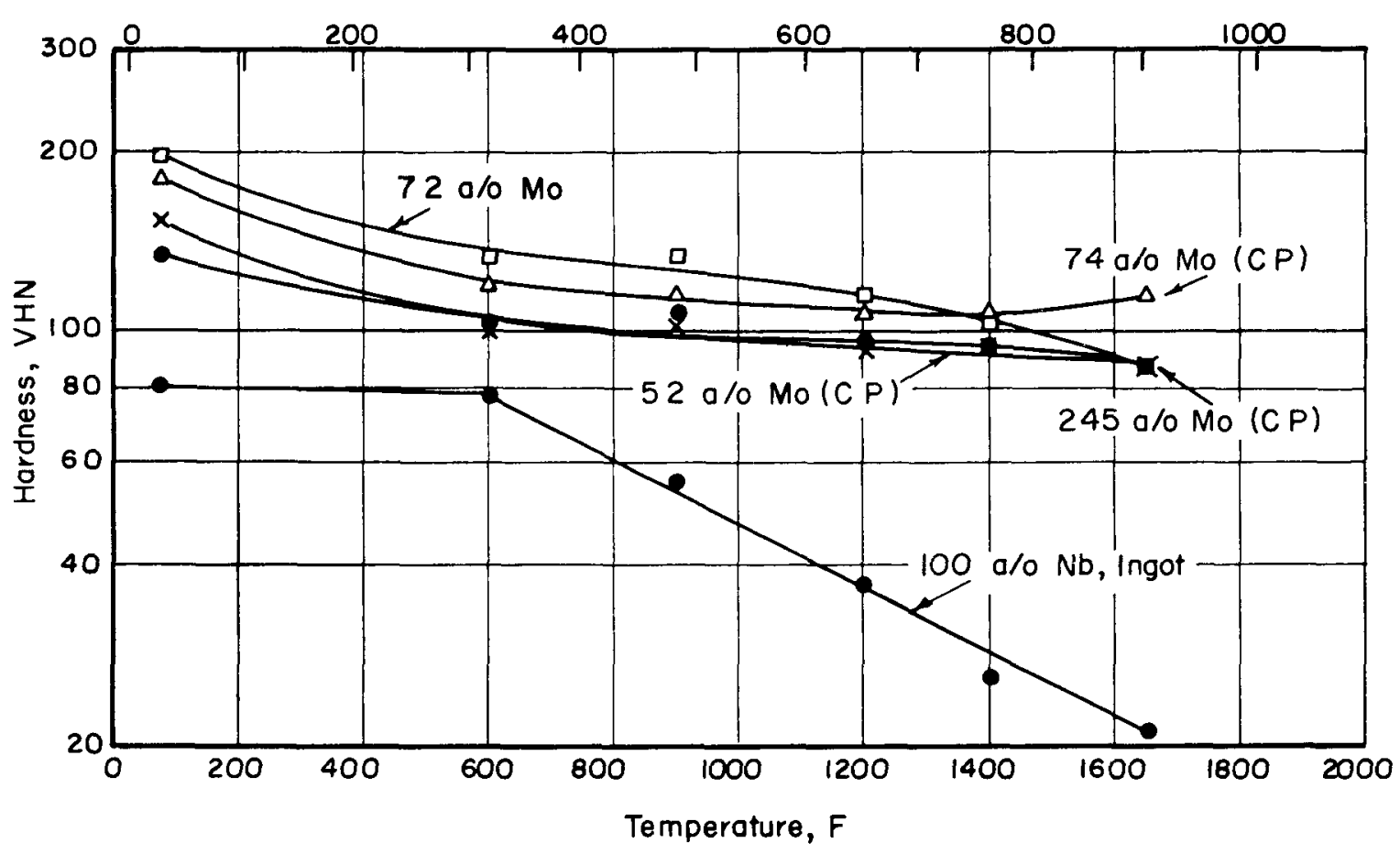

FIGURE 12. HOT HARDNESS OF NIOBIUM-MOLYBDENUM ALLOYS

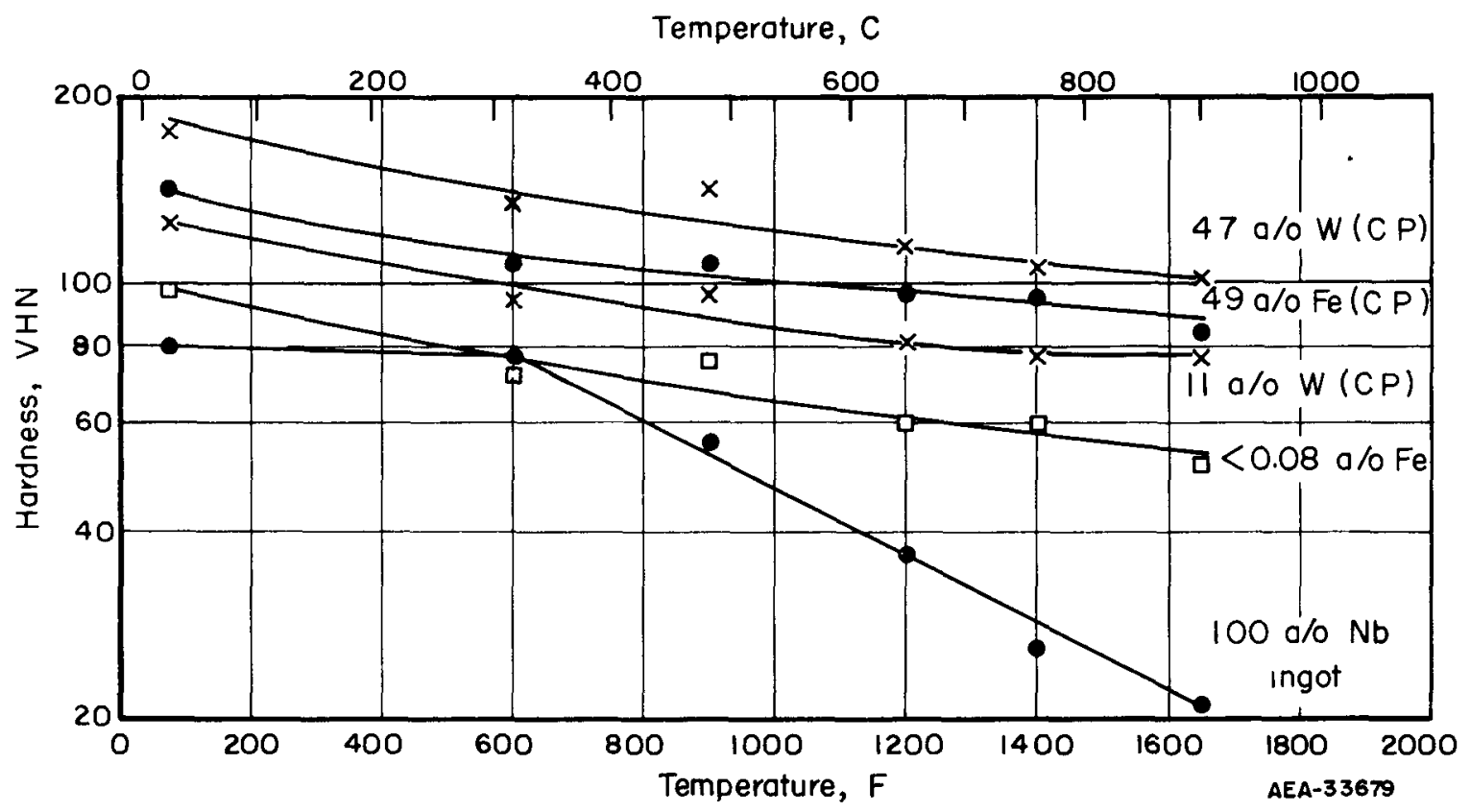

FIGURE 13. HOT HARDNESS OF NIOBIUM-TUNGSTEN AND NIOBIUM-IRON ALLOYS 


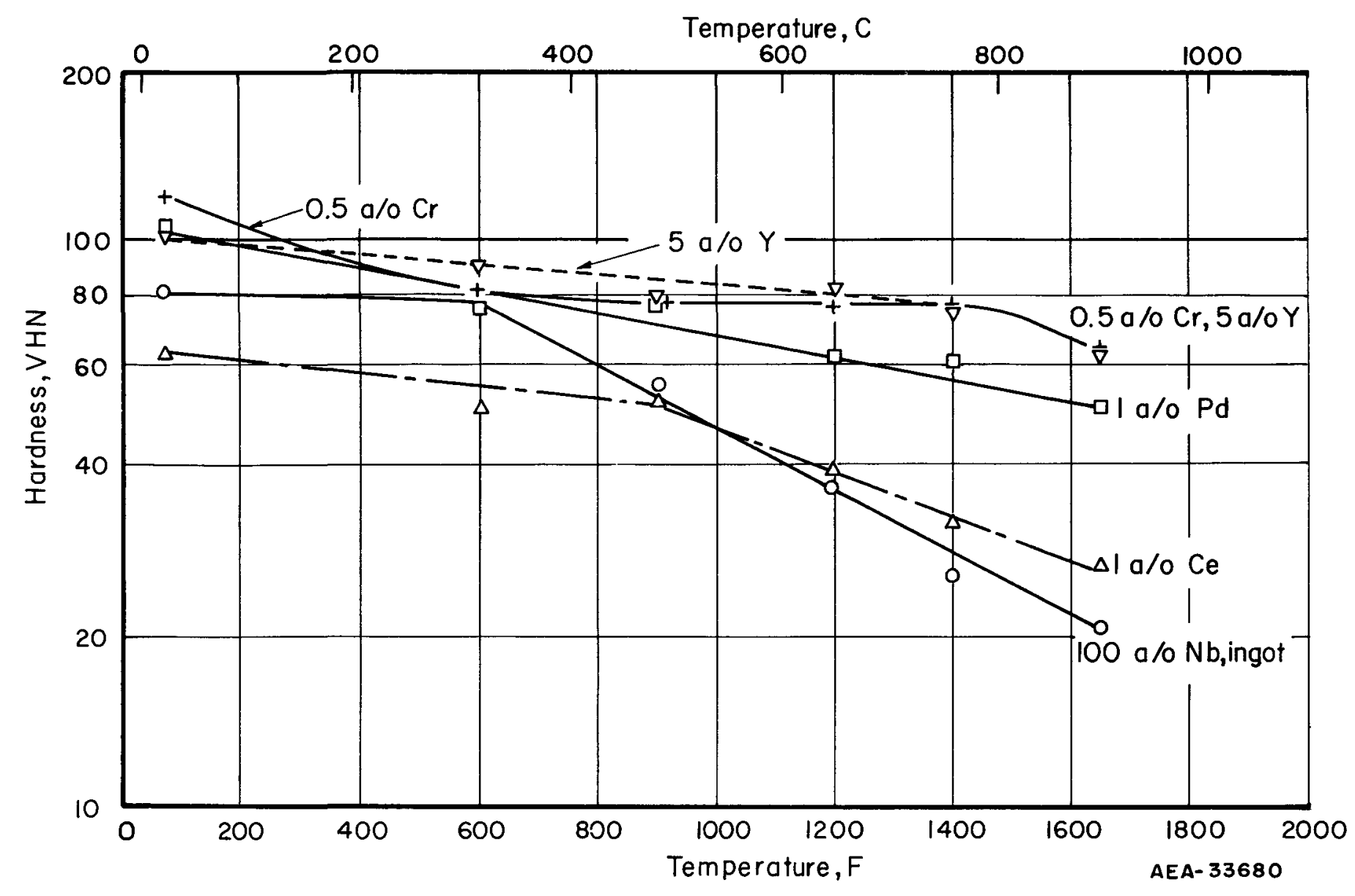

FIGURE 14. HOT HARDNESS OF MISCELLANEOUS BINARY NIOBIUM-BASE ALLOYS 

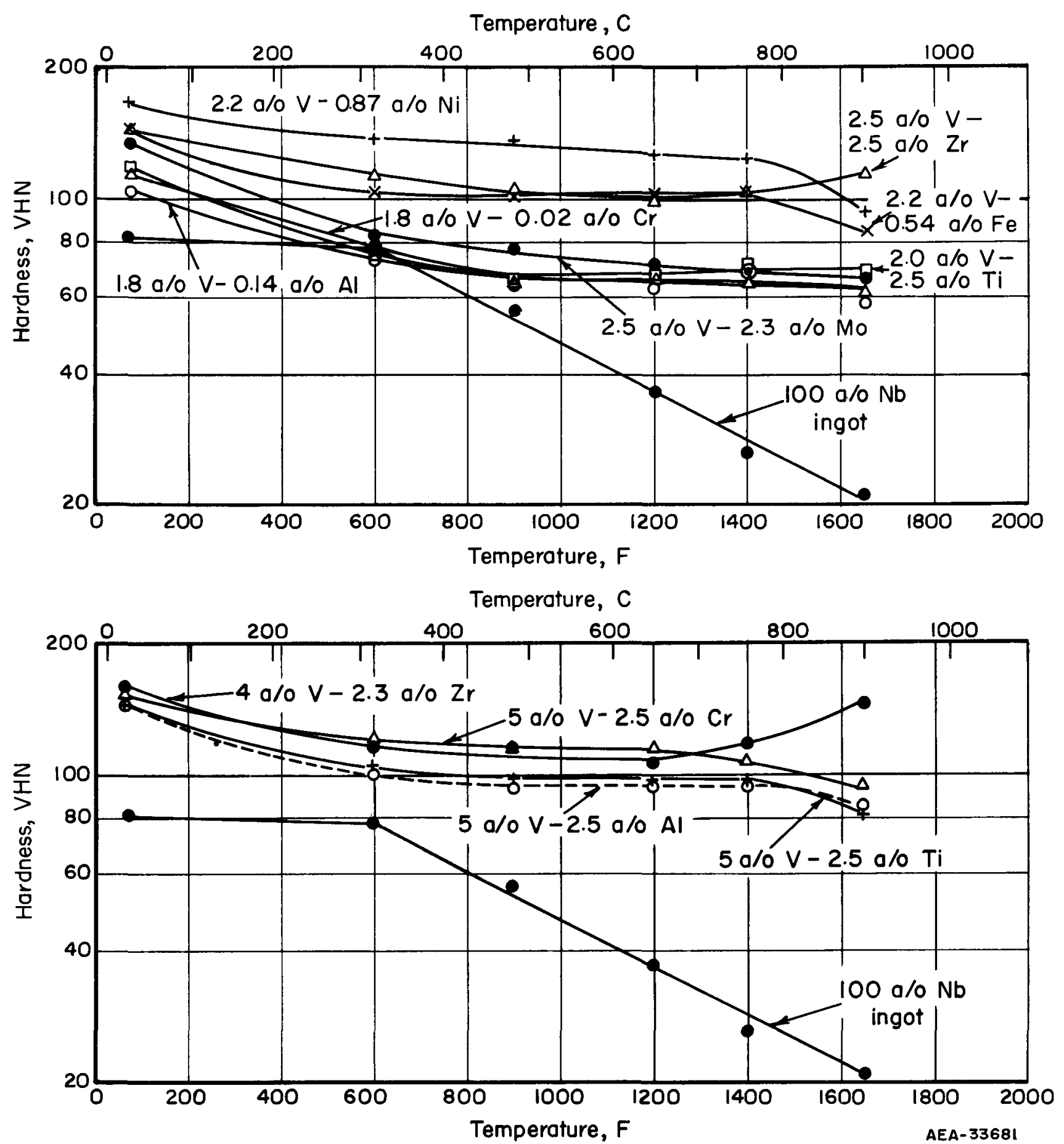

FIGURE 15. HOT HARDNESS OF TERNARY NIOBIUM-VANADIUM-BASE ALLOYS 

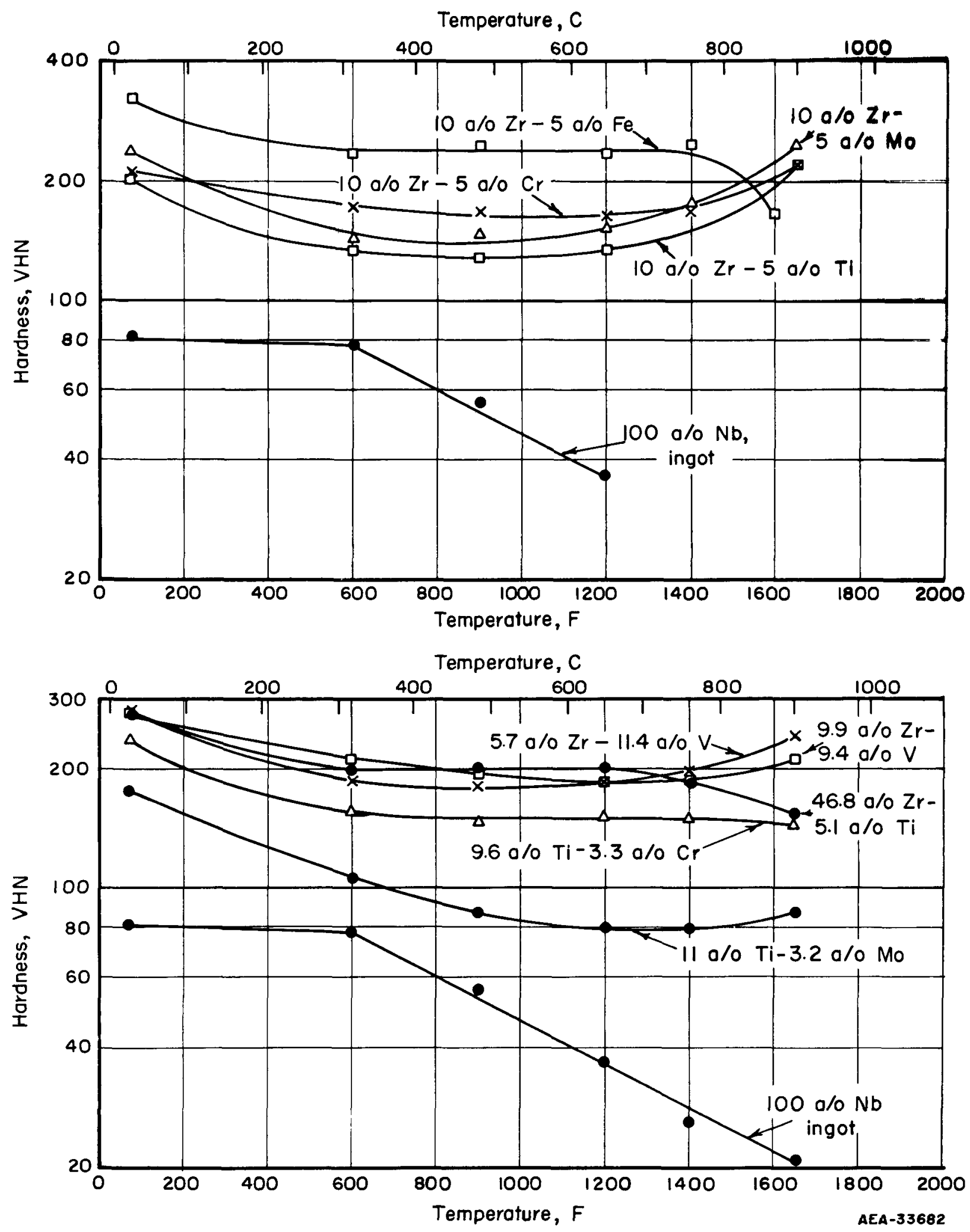

FIGURE 16. HOT HARDNESS OF TERNARY NIOBIUM-ZIR CONIUM- AND NIOBIUMTITANIUM-BASE ALLOYS 


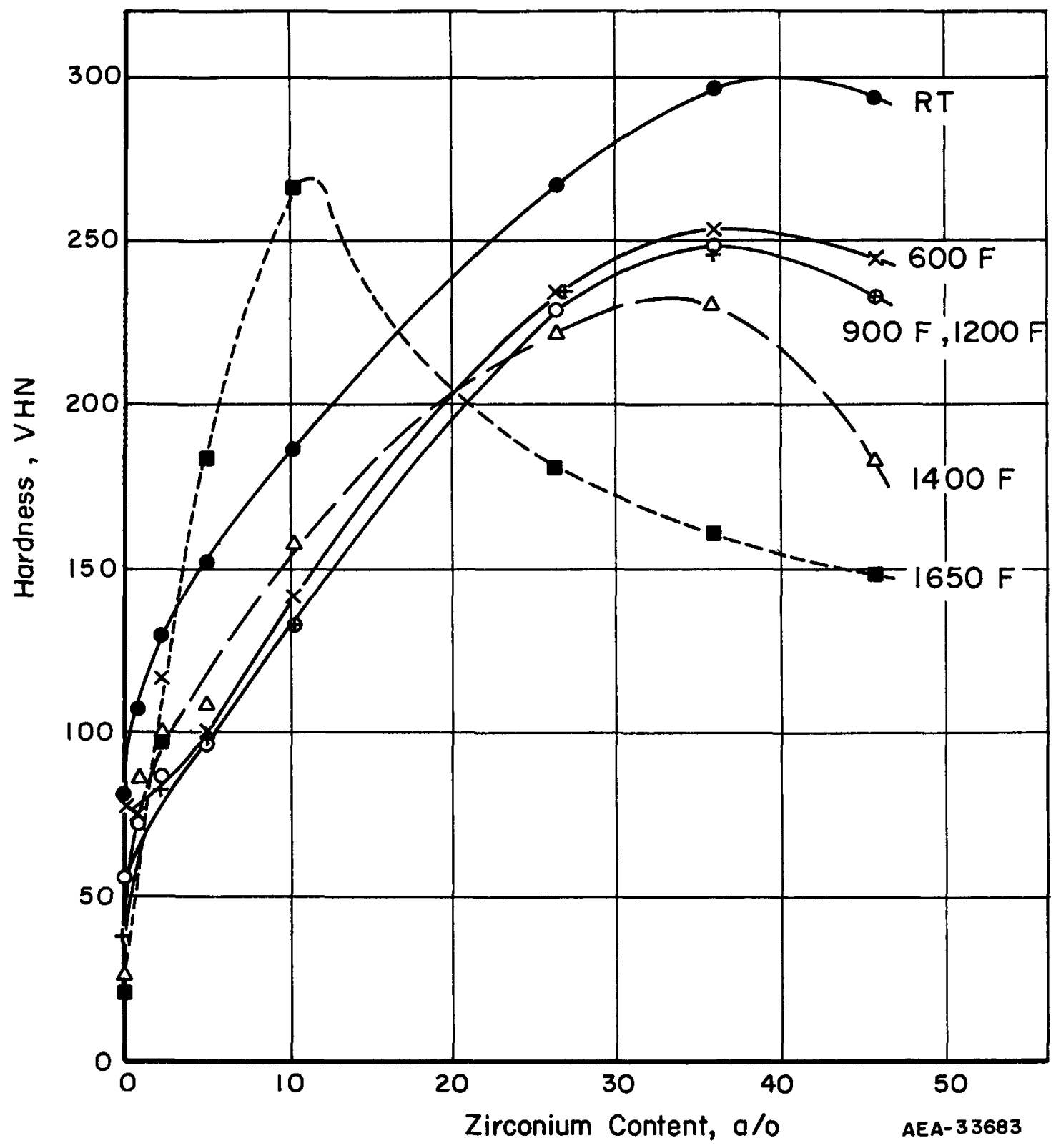

FIGURE 17. EFFECT OF ZIRCONIUM ON THE HOT HARDNESS OF NIOBIUM 


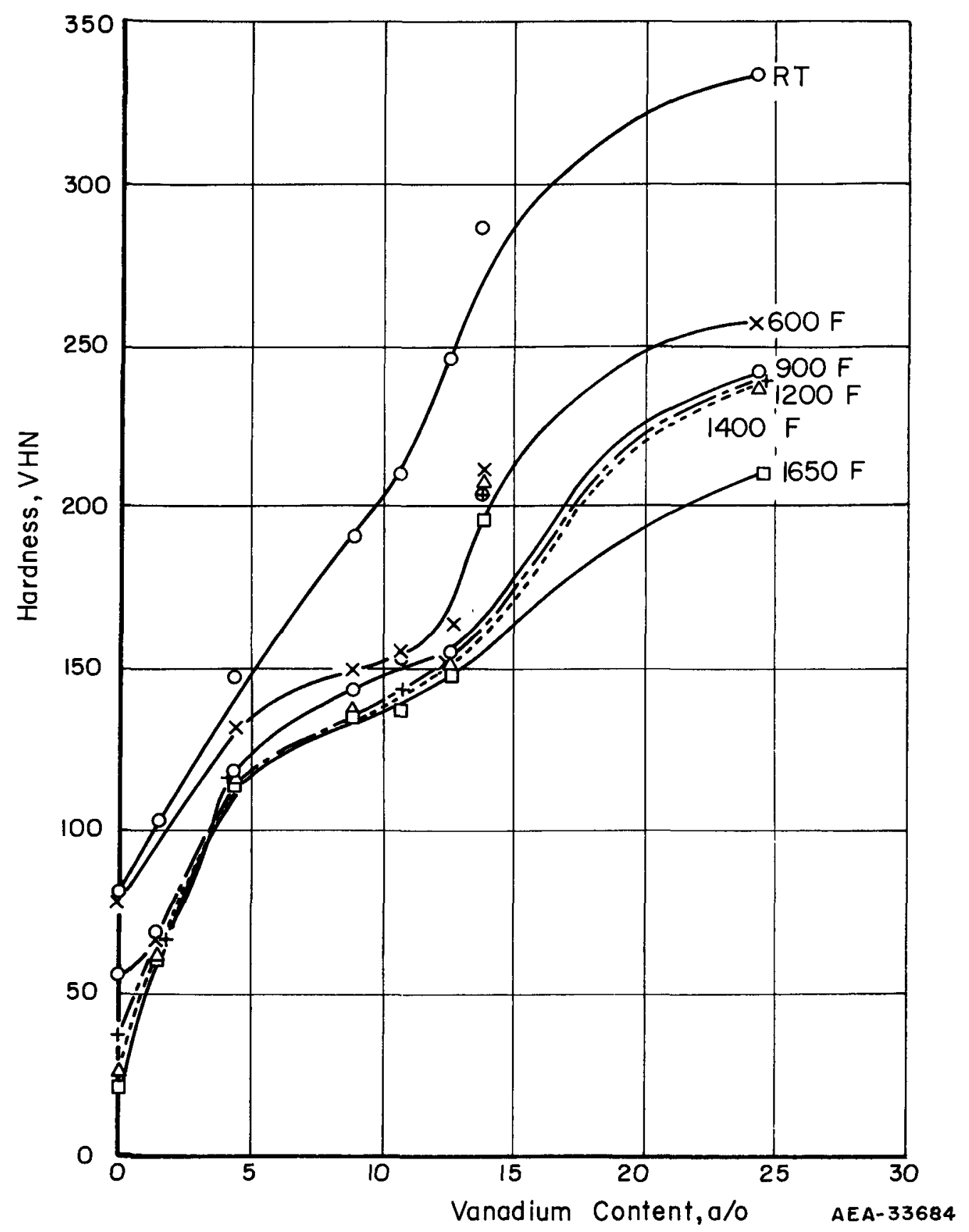

FIGURE 18. EFFECT OF VANADIUM ON THE HOT HARDNESS OF NIOBIUM 

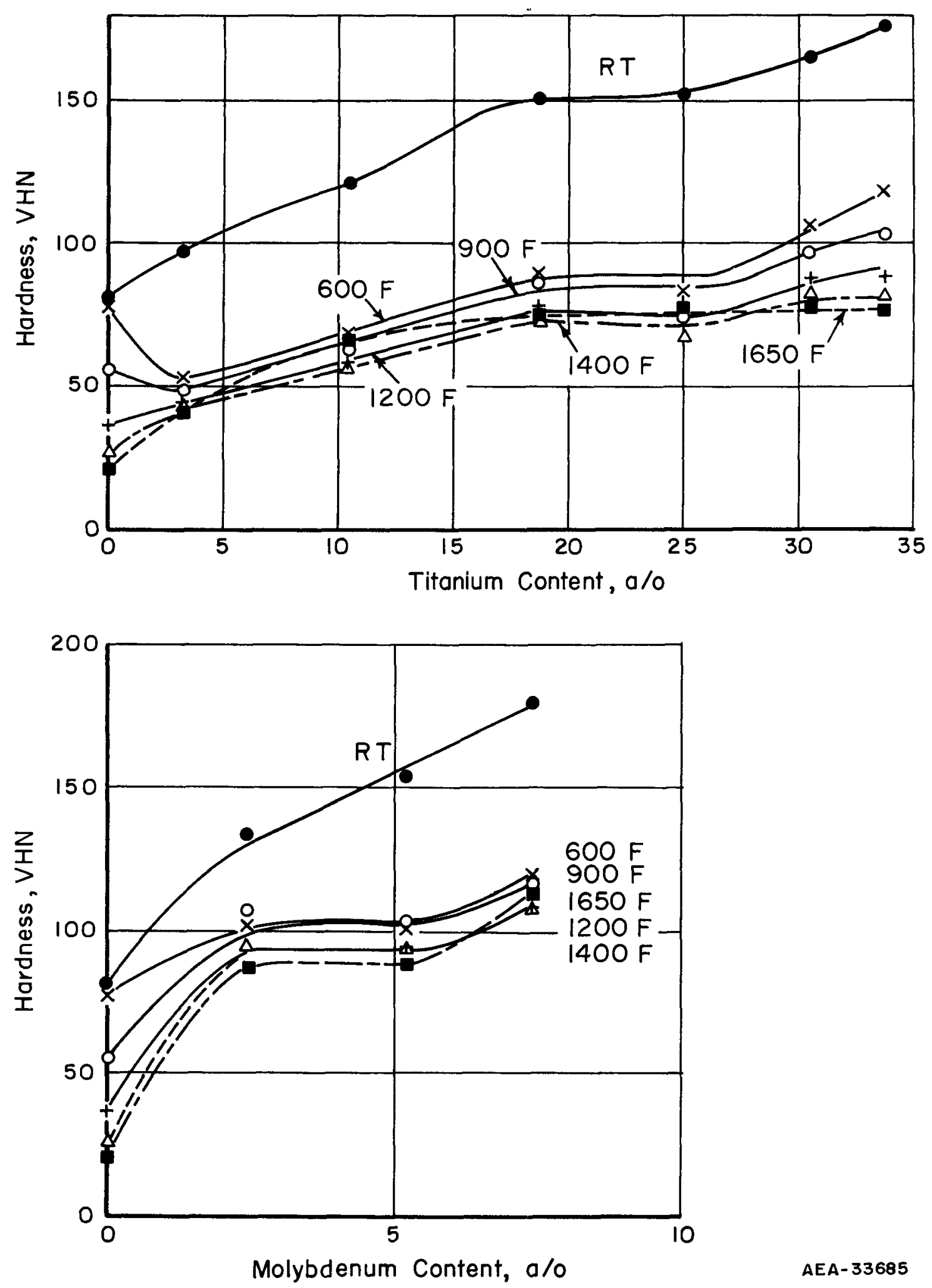

AEA-33685

FIGURE 19. EFFECTS OF TITANIUM AND MOLYBDENUM ON THE HOT HARDNESS OF NIOBIUM 
hardness of niobium. Binary additions of these metals in larger amounts have a lesser effect in further increasing the alloys' hardnesses. As shown in Figure 19, titanium is much less effective than any of these other elements in improving the hot hardness of niobium. Neglecting contamination effects, the order of these elements on an equivalent percentage ( 5 to $7 \mathrm{a} / \mathrm{o}$ ) basis in increasing the hot hardness of niobium is titanium, zirconium, molybdenum, and vanadium.

Comparison of the ternary-alloy data shows that, in combination with vanadium or zirconium, iron and nickel additions appear more effective in increasing the hardness of niobium at elevated temperatures than similar amounts of molybdenum or titanium.

The effect of time on the hardness of the 12.6 a/o vanadium and $7.2 \mathrm{a} / \mathrm{o}$ molybdenum alloys at $1200 \mathrm{~F}$ was determined as shown in Figure 20. For both alloys, the resistance to deformation decreases slightly, at about the same rate, with increasing times up to $2000 \mathrm{sec}$.

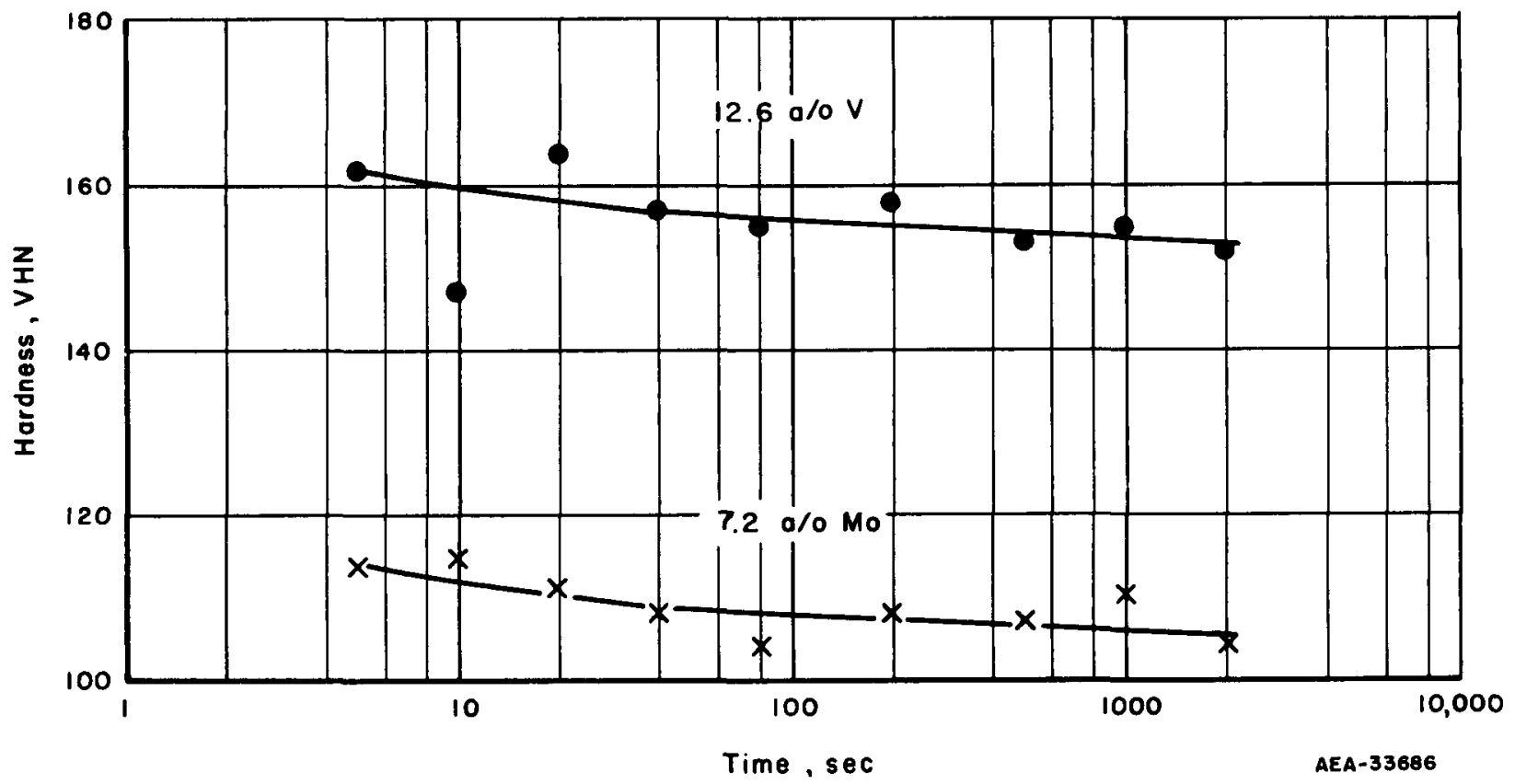

FIGURE 20. EFFECT OF TIME ON THE HARDNESS OF TWO NIOBIUM-BASE ALLOYS AT $1200 \mathrm{~F}$

Tensile Properties

The tensile properties of the first scaleup alloys prepared were determined at temperatures through $1200 \mathrm{~F}$, the highest temperature deemed of practical interest for pressurized water applications. Later, tests on some of the alloys were extended to $1500 \mathrm{~F}$. The latter temperature was primarily selected for testing the screening alloys, for which only sufficient material for a single tensile sample was available. Here, the $1500 \mathrm{~F}$ ultimate tensile strength was calculated*, as being approximately equivalent to Calculated using the Larson-Miller parameter, $P=T(C+\log t) 10^{-3}$ where $T=$ absolute temperature, $t=t$ time, hr, and $C=$ a constant having an estimated value of 20 . 
TABLE 20. TENSILE PROPERTIES AND BEND

\begin{tabular}{|c|c|c|c|c|c|c|}
\hline \multirow[b]{3}{*}{ Alloy } & \multirow[b]{3}{*}{$\begin{array}{c}\text { Alloy Content } \\
\text { (Balance Niobium), } \\
\text { a/o }\end{array}$} & \multirow[b]{3}{*}{$\begin{array}{c}\text { Annealing } \\
\text { Temperature, } \\
\text { F }\end{array}$} & \multirow[b]{3}{*}{$\begin{array}{c}\text { Minımum } \\
\text { Bend Radius, } \\
T \text { (a) }\end{array}$} & \multicolumn{3}{|r|}{ Tensile } \\
\hline & & & & \multicolumn{3}{|c|}{ Room Temperature } \\
\hline & & & & $\begin{array}{l}0.2 \text { Per Cent } \\
\text { Offset Yield } \\
\text { Strength, } \\
1000 \text { psi }\end{array}$ & $\begin{array}{l}\text { Ultumate } \\
\text { Strength, } \\
1000 \text { psi }\end{array}$ & $\begin{array}{l}\text { Elongation } \\
\text { in } 1 \text { In. , } \\
\text { per cent }\end{array}$ \\
\hline \multirow[t]{2}{*}{$\mathrm{TP}-37$} & $100 \mathrm{Nb}$ & 2730 & 0 & 20.5 & 26 & 28 \\
\hline & & 2190 & 0 & 22 & 32 & 43 \\
\hline$N L-11$ & $7.6 \mathrm{~V}$ & 2190 & -- & 51.5 & 75 & 29 \\
\hline NL -12 & $8.7 \mathrm{~V}-0.26 \mathrm{~N}$ & 2190 & -- & 65.5 & 87 & 18 \\
\hline NL -13 & $7.3 \mathrm{~V}-2.4 \mathrm{~T} 1$ & 2190 & -- & 44 & 78 & 27 \\
\hline $\mathrm{NL}-14$ & $7.6 \mathrm{~V}-2.3 \mathrm{Mo}$ & 2190 & - & 59 & 84 & 28 \\
\hline NL-2 & $12.6 \mathrm{~V}$ & 2730 & 0 & 79 & 97 & 24 \\
\hline NL-3 & $7.2 \mathrm{Mo}$ & 2730 & $0-1.0$ & 63 & 77 & 20 \\
\hline $\mathrm{NL}-4$ & $46.8 \mathrm{Zr}-5.1 \mathrm{~T}_{1}$ & 2730 & $3->12.7$ & 124 & 128 & 8 \\
\hline$N L-6$ & $18.8 \mathrm{Tl}-8.7 \mathrm{Mo}$ & 2730 & Brittle & -- & $\sim 25$ & 0 \\
\hline NL -7 & $11.2 \mathrm{Tl}-3.2 \mathrm{Mo}$ & 2730 & $1.5-3.1$ & 57 & 67 & 35 \\
\hline $\mathrm{NL}-8$ & $9.4 \mathrm{~V}-9.9 \mathrm{Zr}$ & 2730 & Brittle & -- & 91 & 0 \\
\hline NL -9 & $11.4 \mathrm{~V}-5.7 \mathrm{Zr}$ & 2730 & Brittle & -- & 46 & 0 \\
\hline $\mathrm{NL}-10$ & $9.6 \mathrm{Tl}_{1}-3.3 \mathrm{Cr}$ & 2730 & Brittle & -- & 73 & 0 \\
\hline
\end{tabular}

(a) $\mathrm{T}$-value expresses the ratio of smallest successful bend radius to thickness of the sheet used; generally $\mathrm{T}$-values greater than 10 indicate brittle behavior.

(b) $1200 \mathrm{~F}$ and $1500 \mathrm{~F}$ tensile tests conducted in helium; all others carned out in air.

(c) Fracture of loading pin in shoulder occurred. 
DUCTILITIES OF NIOBIUM-BASE SCALEUP ALLOYS

\begin{tabular}{|c|c|c|c|c|c|c|c|c|}
\hline \multicolumn{9}{|c|}{ Properties at Temperatures Indicated } \\
\hline \multicolumn{3}{|c|}{$600 \mathrm{~F}$} & \multicolumn{3}{|c|}{$1200 \mathrm{~F}^{(\mathrm{b})}$} & \multicolumn{3}{|c|}{$1500 F(b)$} \\
\hline 0.2 Per Cent & & & 0.2 Per Cent & & & 0.2 Per Cent & & \\
\hline $\begin{array}{l}\text { Offset Yield } \\
\text { Strength, } \\
1000 \text { psi }\end{array}$ & $\begin{array}{l}\text { Ultimate } \\
\text { Strength, } \\
1000 \text { psi }\end{array}$ & $\begin{array}{l}\text { Elongation } \\
\text { in } 1 \mathrm{In} ., \\
\text { per cent }\end{array}$ & $\begin{array}{l}\text { Offset Yield } \\
\text { Strength, } \\
1000 \text { psi }\end{array}$ & $\begin{array}{l}\text { Ultimate } \\
\text { Strength, } \\
1000 \text { psi }\end{array}$ & $\begin{array}{l}\text { Elongation } \\
\text { in } 1 \mathrm{ln} . \text {, } \\
\text { per cent }\end{array}$ & $\begin{array}{l}\text { Offset Yield } \\
\text { Strength, } \\
1000 \text { psi }\end{array}$ & $\begin{array}{l}\text { Ultimate } \\
\text { Strength, } \\
1000 \text { psi }\end{array}$ & $\begin{array}{l}\text { Elongation } \\
\text { in } 1 \text { In. , } \\
\text { per cent }\end{array}$ \\
\hline 12 & 25 & 32 & 8.7 & 13 & 23 & -- & -- & -- \\
\hline-- & -- & -- & 32 & 58 & 17 & 34 & 53 & 34 \\
\hline- & -- & -- & 38 & 64.5 & 15 & 42 & 60 & 26 \\
\hline-- & -- & -- & 38 & 62 & 14 & 34 & 53.5 & 23 \\
\hline-- & -- & -- & 36 & 64 & 18 & 34 & 55 & 28 \\
\hline 57 & 81 & 23 & 49 & 77 & 18 & 47 & $>69^{(c)}$ & $>8(c)$ \\
\hline 46 & 67 & 14 & 36 & 44 & 3 & -- & -- & -- \\
\hline 87 & 101 & $\sim 6$ & -- & 78 & 3 & -- & -- & -- \\
\hline 17 & 17 & $\sim 1$ & 32 & 33 & 2 & - & -- & -- \\
\hline 31 & 42 & 32 & 22 & 39 & 21 & -- & -- & -- \\
\hline-- & -- & - & -- & 65 & 2 & - & -- & -- \\
\hline-- & -- & -- & -- & 38 & 1 & -- & -- & -- \\
\hline-- & - & -- & 62 & 74 & 3 & -- & -- & -- \\
\hline
\end{tabular}


the 100-hr rupture strength of the alloys at $1200 \mathrm{~F}$. Unfortunately, due to time limitations, it was not possible to test all of the screening alloys at $1500 \mathrm{~F}$. Accordingly, the remainder were tested at room temperature.

The results of both room- and elevated-temperature tests on each on the scaleup alloys are given in Table 20. Table 21 summarizes the results of all of the roomtemperature tensile data obtained on both the scaleup and screening alloys.

Room Temperature

The unalloyed niobium base, annealed for $1 \mathrm{hr}$ at $2730 \mathrm{~F}$, showed low yield and ultimate strengths $(20,500$ and $26,000 \mathrm{psi}$, respectively) characteristic of this highpurity material. The comparatively low tensile elongation, 28 per cent, of this sample was due to the extremely large grain size (see Figure 5a) which resulted from the $2730 \mathrm{~F}$ anneal. Recrystallizing this material at $2190 \mathrm{~F}$ gave a much finer grain size (similar to that shown in Figure $5 \mathrm{~b}$ ) and increased the tensile elongation value to 43 per cent. Yield and ultimate strengths were increased, accordingly, to 22,000 and 32,000 psi, respectively.

Generally, as expected, all of the alloying additions increased the strength of niobium at the expense of decreasing its ductility.

Of the few binary alloys tested, the results at the 1-5 a/o alloy level show that yttrium, palladium, and nickel, in that order, are increasingly more effective in strengthening niobium. The 2.5 a/o nickel addition approximately doubled the strength of the niobium and halved its tensile elongation. The strengths obtained with this alloy are quite high and compare favorably with the strengthening effect obtained by much larger (about $7.5 \mathrm{a} / \mathrm{o}$ ) additions of molybdenum or vanadium. The best combination of high strength and ductility was obtained in the binary 12.6 a/o vanadium alloy which has yield and ultimate strengths of 79,000 and $97,000 \mathrm{psi}$, respectively, and an elongation of 24 per cent.

Of the various ternary alloys tested, good combinations of strength and ductility were generally obtained in all of those with a niobium-vanadium base excepting those containing 5 to 10 a/o zirconium. At the 2.5 to 5 a/o vanadium level, the addition of $0.5 \mathrm{a} / \mathrm{o}(0.09 \mathrm{w} / \mathrm{o})$ oxygen - in combination with small amounts $(0.25$ to $0.5 \mathrm{a} / \mathrm{o})$ titanium or zirconium - results in higher strengths and lower ductilities than the addition of $0.5 \mathrm{a} / 0(0.07 \mathrm{w} / \mathrm{o})$ carbon. At 5 a/o vanadium, the nominal 2.5 a/o ternary additions of aluminum, chromium, and iron are not as effective in strengthening as are additions of nitrogen or oxygen. Similarly, at vanadium levels of 7.3 to $8.7 \mathrm{a} / \mathrm{o}, 0.26 \mathrm{a} / \mathrm{o}(0.04$ w/o) nitrogen has a more potent strengthening effect than 2.5 a/o additions of either titanium or molybdenum. It is thus apparent that interstitial additions to niobiumvanadium alloys have a powerful strengthening effect yet do not seriously impair their room-temperature tensile ductility.

Despite its comparatively high total alloy content, the 11.2 a/o titanium- 3.2 a/o molybdenum alloy is not as strong as either the binary 7.2 a/o molybdenum or 7.6 a/o vanadium alloys. 
TABLE 21. SUMMARIZED ROOM-TEMPERATURE TENSILE PROPERTIES OF NIOBIUM-BASE ALLOYS

\begin{tabular}{|c|c|c|c|c|c|c|}
\hline \multirow[b]{2}{*}{ Alloy } & \multirow[b]{2}{*}{$\begin{array}{c}\text { Alloy Content } \\
\text { (Balance Niobium), a/o }\end{array}$} & \multirow[b]{2}{*}{$\begin{array}{c}\text { Annealing } \\
\text { Temperature, } \\
\text { F }\end{array}$} & \multirow[b]{2}{*}{$\begin{array}{l}\text { Hardness, } \\
\text { VHN }\end{array}$} & \multicolumn{3}{|c|}{ Tensile Properties } \\
\hline & & & & $\begin{array}{l}0.2 \text { Per cent } \\
\text { Offset Yield } \\
\text { Strength, } \\
1000 \mathrm{psi}\end{array}$ & $\begin{array}{l}\text { Ultimate } \\
\text { Strength, } \\
1000 \text { psi }\end{array}$ & $\begin{array}{l}\text { Elongation, in } \\
1 \text { In. , per cent }\end{array}$ \\
\hline \multirow[t]{2}{*}{ TP37 } & $100 \mathrm{Nb}$ & 2190 & -- & 22 & 32 & 43 \\
\hline & & 2730 & 81 & 20.5 & 26 & 28 \\
\hline N59 & $1 \mathrm{Y}^{(\mathrm{a})}$ & 2190 & 94 & 24 & 36 & 19 \\
\hline N60 & $5 Y^{(a)}$ & 2190 & 109 & 31 & 42 & 20 \\
\hline N61 & $1 \mathrm{Ni}(\mathrm{a})$ & 2190 & 144 & 43 & 58 & 22 \\
\hline N62 & $2.5 \mathrm{Ni}(\mathrm{a})$ & 2190 & 171 & 50 & 69 & 20 \\
\hline N64 & $1 \mathrm{Pd}(\mathrm{a})$ & 2190 & 134 & 31 & 44 & 40 \\
\hline NL3 & $7.2 \mathrm{No}$ & 2730 & 199 & 63 & 77 & 20 \\
\hline N71 & $2.5 \mathrm{~V}-0.5 \mathrm{C}^{(\mathrm{a})}$ & 2190 & 130 & 33 & 55 & 20 \\
\hline N77 & $2.5 \mathrm{~V}-0.5 \mathrm{Ti}-0.5 \mathrm{c}^{(\mathrm{a})}$ & 2190 & 127 & 30 & 53 & 29 \\
\hline N79 & $2.5 \mathrm{~V}-0.5 \mathrm{Zr}-0.5 \mathrm{C}^{(\mathrm{a})}$ & 2190 & 163 & 40.5 & 67 & 24 \\
\hline N80 & $5 \mathrm{~V}-0.5 \mathrm{Zr}_{\mathrm{r}}-0.5 \mathrm{C}^{(\mathrm{a})}$ & 2190 & 198 & 49.5 & 82 & 25 \\
\hline N73 & $2.5 \mathrm{~V}-0.25 \mathrm{Ti}-0.5 \mathrm{O}(\mathrm{a})$ & 2190 & 161 & 54 & 71 & 22 \\
\hline N75 & $2.5 \mathrm{~V}-0.25 \mathrm{Zr}-0.5 \mathrm{O}^{(\mathrm{a})}$ & 2190 & 158 & 57 & 71 & 10 \\
\hline N76 & $5 \mathrm{~V}-0.5 \mathrm{Zr}-0.5 \mathrm{O}^{(\mathrm{a})}$ & 2190 & 163 & 54 & 75 & 24 \\
\hline N67 & $5 \mathrm{~V}-2.5 \mathrm{Fe}^{(\mathrm{a})}$ & 2190 & 169 & 48 & 70 & 20 \\
\hline N68 & $5 \mathrm{~V}-2.5 \mathrm{Cr}^{(\mathrm{a})}$ & 2190 & 149 & 41 & 65 & 30 \\
\hline N70 & $5 \mathrm{~V}-2.5 \mathrm{Al}^{(\mathrm{a})}$ & 2190 & 144 & 42 & 64 & 30 \\
\hline NL-11 & $7.6 \mathrm{~V}$ & 2190 & 176 & 51.5 & 75 & 29 \\
\hline NL-12 & $8.7 \mathrm{~V}-0.26 \mathrm{~N}$ & 2190 & 207 & 65.5 & 87 & 18 \\
\hline$N L-13$ & $7.3 \mathrm{~V}-2.4 \mathrm{Ti}$ & 2190 & 193 & 44 & 78 & 27 \\
\hline NL-14 & $7.6 \mathrm{~V}-2.3 \mathrm{Mo}$ & 2190 & 205 & 59 & 84 & 28 \\
\hline $\mathrm{NL}-2$ & $12.6 \mathrm{~V}$ & 2730 & 246 & 79 & 97 & 24 \\
\hline NL-8 & $9.4 \mathrm{~V}-9.9 \mathrm{Zr}$ & 2730 & 277 & -- & 91 & 0 \\
\hline $\mathrm{NL}-9$ & $11.4 \mathrm{~V}-5.7 \mathrm{Zr}$ & 2730 & 275 & -- & 46 & 0 \\
\hline $\mathrm{NL}-10$ & $9.6 \mathrm{Ti}-3.3 \mathrm{Cr}$ & 2730 & 239 & -- & 73 & 0 \\
\hline NL-7 & 11. $2 \mathrm{Ti}-3.2 \mathrm{Mo}$ & 2730 & 178 & 57 & 67 & 35 \\
\hline $\mathrm{NL}-6$ & $18.8 \mathrm{Ti}-8.7 \mathrm{Mo}$ & 2730 & -- & -- & $\sim 25$ & 0 \\
\hline $\mathrm{NL}-4$ & $46.8 \mathrm{Z}[-5.1 \mathrm{Ti}$ & 2730 & 282 & 124 & 128 & 8 \\
\hline
\end{tabular}

(a) Nominal composition. 
The highest room-temperature strength (128,000 psi ultimate) was obtained on the 46.8 a/o zirconium-5. 1 a/o titanium alloy. However, the fairly small spread (4, 000 psi) between the yield and ultimate strength of this alloy and its low tensile elongation ( 8 per cent) indicate its capacity for cold plastic deformation is quite limited.

As shown by the data of Tables 20 and 21 , four of the ternary alloys proved to be quite brittle, as evidenced by their complete lack of tensile and bend ductility at room temperature. These include the 9.4 a/o vanadium- $9.9 \mathrm{a} / 0 \mathrm{zirconium,} 11.4 \mathrm{a} / 0$ vanadium-5. 7 a/o zirconium, 9.6 a/o titanium- $3.3 \mathrm{a} / 0 \mathrm{chromium}$, and $18.8 \mathrm{a} / \mathrm{o}$ titanium-8. 7 a/o molybdenum alloys.

The brittle behavior of the se vanadium-zirconium alloys is believed primarily due to their high interstitial content as a result of contamination in their preparation (see data of Table 5). As noted earlier, both of these alloys contained appreciable amounts of an inter- and intergranular zirconium-rich second phase (see Figure 1d). It appears possible, therefore, that the presence of this phase was also a contributing factor to the brittle behavior of these alloys.

The lack of ductility in the 9.6 a/o titanium-3. 3 a/o chromium alloy probably resulted from chromium segregation and localized precipitation of a brittle phase based on $\mathrm{NbCr}_{2}$ (see Figure 1f).

On the other hand, no explanation can be offered for the lack of ductility in the 18.8 a/o titanium-8. 7 a/o molybdenum alloy.

\section{Elevated Temperatures}

The effects of temperature on the tensile properties of the scaleup alloys are given in Table 20. The same data are plotted, as a function of temperature, in Figures 21, 22, and 23.

The general behavior of the alloys with increasing temperatures through $1200 \mathrm{~F}$ is much the same. Thus, both strengths and ductilities decrease with increasing temperature over this interval. Because the strength drop-off with temperature is similar for most of the alloys, their relative order of $1200 \mathrm{~F}$ strengths, listed below, is about the same as at room temperature.

\begin{tabular}{l} 
Alloy Content, a/o \\
\hline $100 \mathrm{Nb}$ \\
$11.2 \mathrm{Ti}-3.2 \mathrm{Mo}$ \\
$7.2 \mathrm{Mo}$ \\
$7.6 \mathrm{~V}$ \\
$7.3 \mathrm{~V}-2.4 \mathrm{Ti}$ \\
$7.6 \mathrm{~V}-2.3 \mathrm{Mo}$ \\
$8.7 \mathrm{~V}-0.26 \mathrm{~N}$ \\
$12.6 \mathrm{~V}$ \\
$46.8 \mathrm{Zr}-5.1 \mathrm{Ti}$
\end{tabular}

\begin{tabular}{c}
$1200 \mathrm{~F}$ Ultimate Strength, psi \\
\hline 13,000 \\
39,000 \\
44,000 \\
58,000 \\
62,000 \\
64,000 \\
64,500 \\
77,000 \\
78,000
\end{tabular}

At $1500 \mathrm{~F}$, the tensile ductility in the alloys containing 7.3 to 8.7 a/o vanadium show a marked increase (Figure 23) over the $1200 \mathrm{~F}$ values. This indicates recovery for these alloys occurs at or slightly above $1200 \mathrm{~F}$. 
Temperature, $\mathrm{C}$

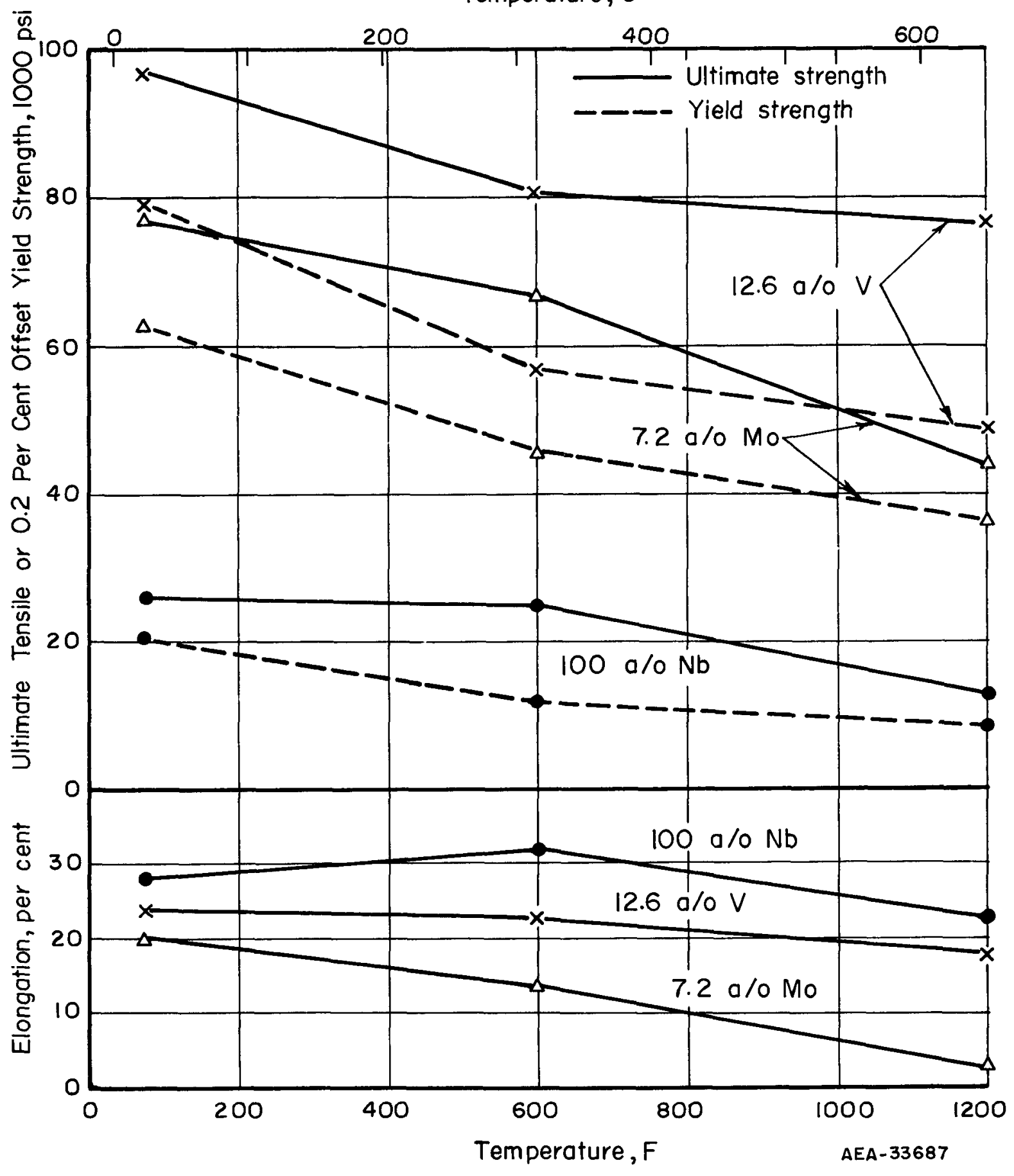

FIGURE 21. EFFECT OF TEMPERATURE ON THE TENSILE PROPERTIES OF NIOBIUM AND THE NIOBIUM-7. 2 a/O MOLYBDENUM AND NIOBIUM-12.6 a/O VANADIUM ALLOYS, AS VACUUM ANNEALED I HR AT $2730 \mathrm{~F}$ 
Temperature, $\mathrm{C}$

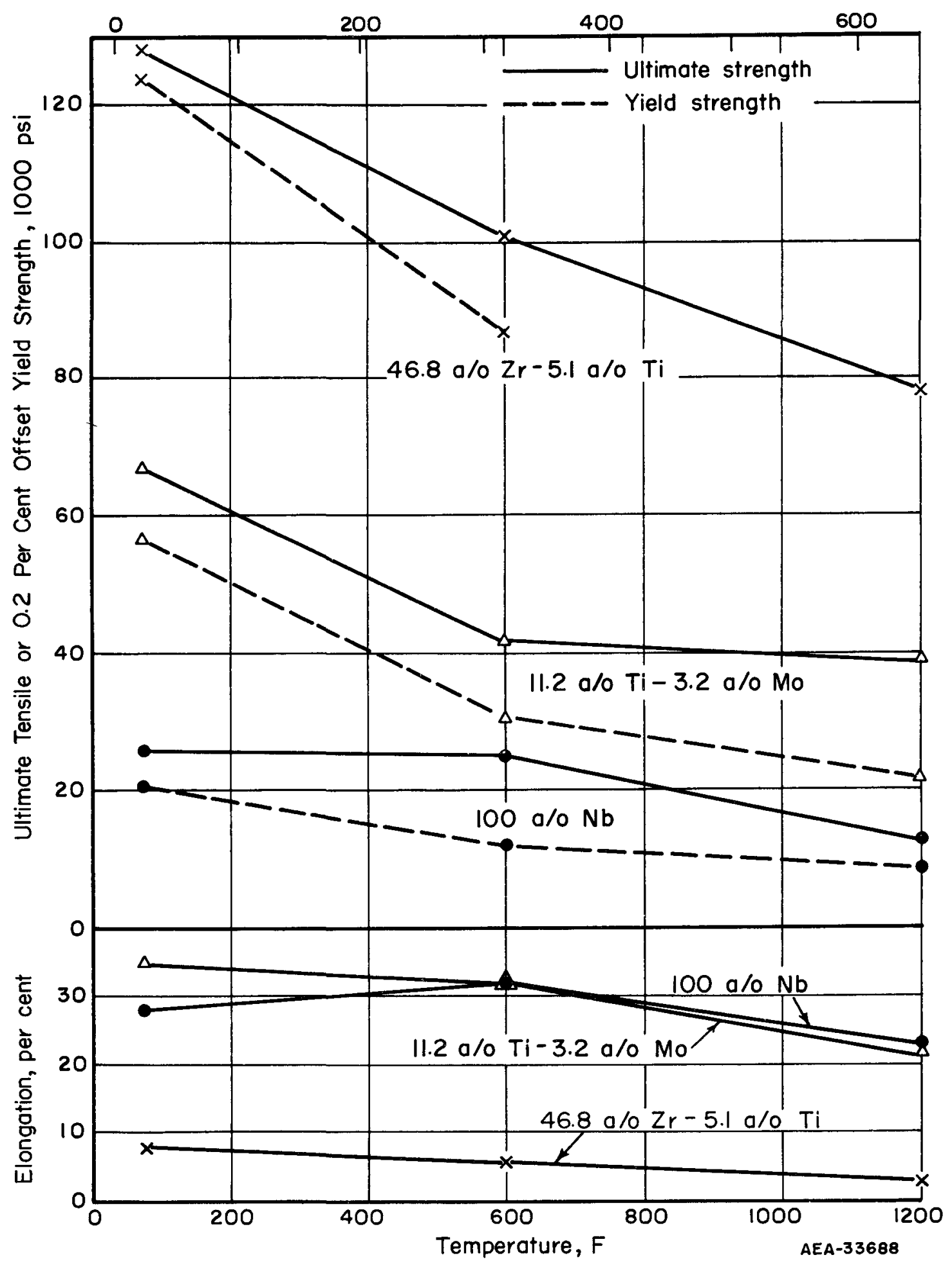

FIGURE 22. EFFECT OF TEMPERATURE ON THE TENSILE PROPERTIES OF NIOBIUM AND THE NIOBIUM-11.2 a/0 TITANIUM-3. 2 a/o MOLYBDENUM AND NIOBIUM-46. 8 a/o ZIRCONIUM-5. 1 a $/ 0$ TITANIUM ALLOYS, AS VACUUM ANNEALED $1 \mathrm{HR}$ AT $2730 \mathrm{~F}$ 

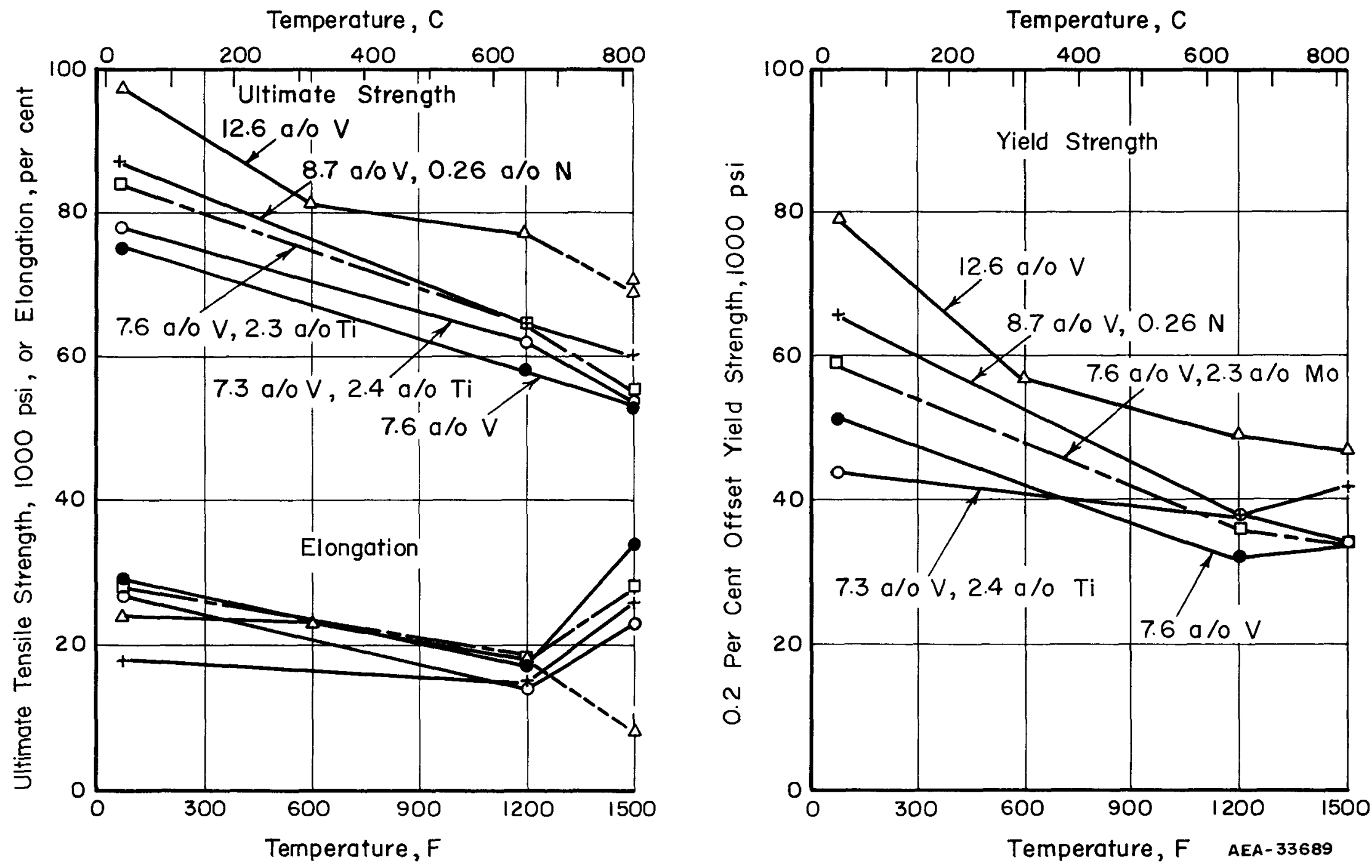

FIGURE 23. EFFECT OF TEMPERATURE ON THE TENSILE PROPERTIES OF NIOBIUM-VANADIUM-BASE ALLOYS 
The $1500 \mathrm{~F}$ tensile properties of all of the alloys tested are summarized in Table 22.

Comparison of the binary-alloy data shows that additions of titanium through 10.5 a/o have no strengthening effect on niobium at $1500 \mathrm{~F}$. While the addition of $2.2 \mathrm{a} / \mathrm{o}$ zirconium results in moderate strengthening, this alloy and each of the three ternary alloys containing zirconium are characterized by extremely low tensile ductilities at $1500 \mathrm{~F}$. This undesirable effect is thus apparently carried over into vanadium-base ternary alloys where the effect of zirconium, at 5 a/o vanadium, is far more severe than the effect of interstitial contaminants (e.g., carbon and oxygen).

As illustrated in Figure 24, vanadium additions through 12.6 a/o result in almost linearly increasing the $1500 \mathrm{~F}$ strength of niobium. As pointed out previously, the higher tensile elongations at $1500 \mathrm{~F}$ for alloys containing vanadium additions up through about 8 a/o apparently results from partial recovery of these alloys at this temperature.

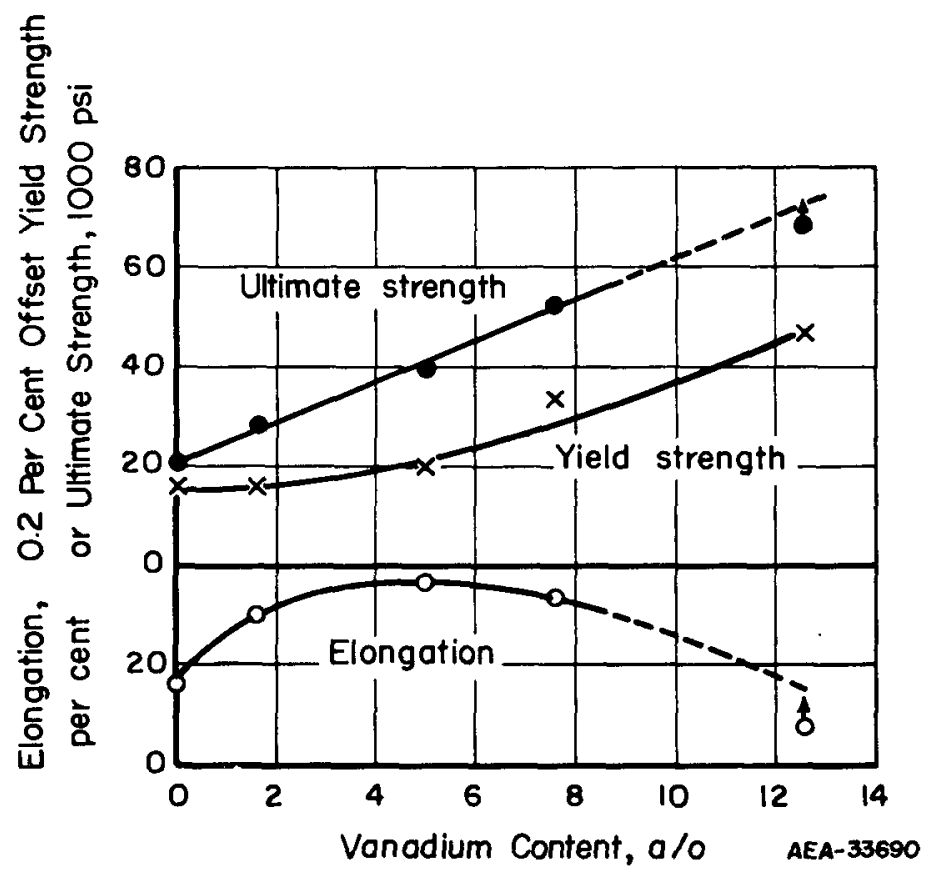

FIGURE 24. EFFECT OF VANADIUM ON THE TENSILE PROPERTIES OF NIOBIUM AT $1500 \mathrm{~F}$

At vanadium levels from 2 to 7.5 a/o, additions of 2.5 a/o titanium or molybdenum are about equivalent in strengthening effect. However, neither titanium nor molybdenum is as effective in improving the hot tensile strength of the niobium-vanadium base as are smaller additions of iron, nickel, nitrogen, or carbon.

In an attempt to correlate the elevated-temperature tensile properties and hardnesses of all the alloys tested, these data were cross plotted with the results shown in Figure 25. As indicated, while the scatter is quite large, the ultimate and yield strengths of niobium alloys at temperatures through $1500 \mathrm{~F}$ may be roughly approximated from hot-hardness data through use of the following relationships:

$$
\begin{gathered}
\operatorname{UTS}_{(\mathrm{psi})}=400 \mathrm{VHN} \\
\mathrm{YS}_{(\mathrm{psi})}=333(\mathrm{VHN}-10) .
\end{gathered}
$$


TABLE 22. SUMMARIZED $1500 \mathrm{~F}$ TENSILE PROPERTIES OF NIOBIUM-BASE ALLOYS

\begin{tabular}{|c|c|c|c|c|c|}
\hline \multirow[b]{2}{*}{ Alloy } & \multirow[b]{2}{*}{$\begin{array}{c}\text { Alloy Content } \\
\text { (Balance Niobium), a/o }\end{array}$} & \multirow[b]{2}{*}{$\begin{array}{c}\text { Annealing } \\
\text { Temperature, } \\
\text { F }\end{array}$} & \multicolumn{3}{|c|}{ Tensile Properties } \\
\hline & & & $\begin{array}{l}0.2 \text { Per Cent } \\
\text { Offset Yield } \\
\text { Strength, } \\
1000 \mathrm{psi}\end{array}$ & $\begin{array}{l}\text { Ultimate } \\
\text { Strength, } \\
1000 \text { psi }\end{array}$ & $\begin{array}{l}\text { Elongation in } \\
1 \text { In. } \\
\text { per cent }\end{array}$ \\
\hline $\mathrm{N} 40$ & $100 \mathrm{Nb}$ & 2190 & 16 & 21 & 18 \\
\hline N57 & $1 \mathrm{Ce}^{(\mathrm{a})}$ & 2190 & 8 & 15 & 30 \\
\hline N3 & $2.2 \mathrm{Zr}$ & 2190 & 30 & 32 & 5 \\
\hline $\mathrm{N} 11$ & $3.2 \mathrm{Ti}$ & 2190 & 14 & 17 & 11 \\
\hline $\mathrm{N} 12$ & $10.5 \mathrm{Ti}$ & 2190 & 12 & 20 & 12 \\
\hline N16 & $1.6 \mathrm{~V}$ & 2190 & 16.5 & 28.5 & 30 \\
\hline N53 & $1.8 \mathrm{~V}-<0.02 \mathrm{Cr}$ & 2190 & 17 & 31 & 51 \\
\hline N54 & $1.8 \mathrm{~V}-0.14 \mathrm{~A} 1$ & 2190 & 16 & 30 & 38 \\
\hline N49 & $2 \mathrm{~V}-2.5 \mathrm{Ti}$ & 2190 & 19 & 35 & 18 \\
\hline N50 & $2 \mathrm{~V}-2.3 \mathrm{Mo}$ & 2190 & 21 & 34 & 29 \\
\hline N51 & $2.2 \mathrm{~V}-0.54 \mathrm{Fe}$ & 2190 & 25 & 43 & 31 \\
\hline N52 & $2.2 \mathrm{~V}-0.87 \mathrm{Ni}$ & 2190 & 38 & 47 & 52 \\
\hline N55 & $2.5 \mathrm{~V}-2.5 \mathrm{Zr}^{(\mathrm{a})}$ & 2190 & -- & 38 & 1 \\
\hline N17 & $4 \mathrm{~V}-2.3 \mathrm{Zr}$ & 2190 & 30 & 46 & 9 \\
\hline N81 & $5 \mathrm{~V}^{(a)}$ & 2190 & 20 & 40 & 37 \\
\hline N65 & $5 \mathrm{~V}-2.5 \mathrm{Ti}^{(\mathrm{a})}$ & 2190 & 23 & 44 & 29 \\
\hline N66 & $5 \mathrm{~V}-2.5 \mathrm{Mo}(\mathrm{a})$ & 2190 & 24 & 43 & $9(b)$ \\
\hline N72 & $5 \mathrm{~V}-0.5 \mathrm{C}^{(\mathrm{a})}$ & 2190 & 30 & 48 & 32 \\
\hline N78 & $5 \mathrm{~V}-0.5 \mathrm{Ti}-0.5 \mathrm{C}^{(\mathrm{a})}$ & 2190 & 26 & 47 & 42 \\
\hline N74 & $5 \mathrm{~V}-0.25 \mathrm{Ti}-0.5 \mathrm{O}^{(\mathrm{a})}$ & 2190 & 35 & 51.5 & 28 \\
\hline NL-11 & $7.6 \mathrm{~V}$ & 2190 & 34 & 53 & 34 \\
\hline NL -12 & $8.7 \mathrm{~V}-0.26 \mathrm{~N}$ & 2190 & 42 & 60 & 26 \\
\hline$N L-13$ & $7.3 \mathrm{~V}-2.4 \mathrm{Ti}$ & 2190 & 34 & 53.5 & 23 \\
\hline$N L-14$ & $7.6 \mathrm{~V}-2.3 \mathrm{Mo}$ & 2190 & 34 & 55 & 28 \\
\hline $\mathrm{NL}-2$ & $12.6 \mathrm{~V}$ & 2730 & 47 & $>69(c)$ & $>8^{(c)}$ \\
\hline $\mathrm{NL}-21$ & $10.9 \mathrm{Zr}-5.1 \mathrm{Ti}$ & 2730 & 34 & 37 & 2 \\
\hline
\end{tabular}

(a) Nominal composition.

(b) Ruptured at pin in shoulder.

(c) Pin in shoulde of tensile sample ruptured. 


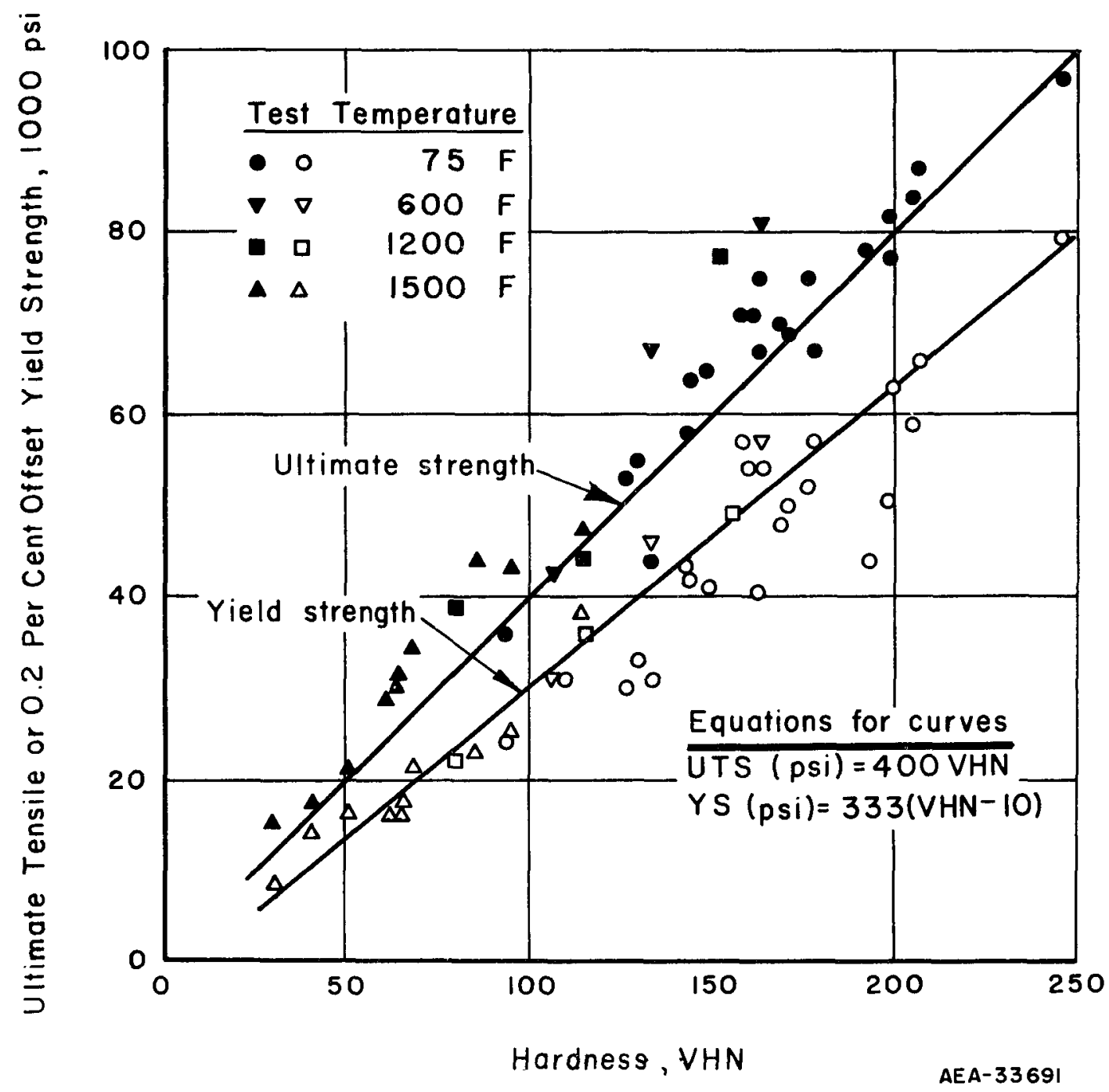

FIGURE 25. CORRELATION OF HOT HARDNESSES TO TENSILE AND YIELD STRENGTHS FOR NIOBIUM-BASE ALLOYS 


\section{Creep Properties}

Creep tests were conducted on each of the fabricable scaleup alloys at 1200 and/or $1380 \mathrm{~F}$. The creep-deformation and -rupture data from all tests are detailed in Table 23 and summarized in Table 24. Typical creep-deformation curves are illustrated in Figure 26.

Stressing the unalloyed niobium base to $6000 \mathrm{psi}$ at $1200 \mathrm{~F}$ resulted in a continuously decreasing rate of creep, even though the total deformation approached 6 per cent in $265 \mathrm{hr}$. At the time this test was discontinued $(265 \mathrm{hr})$, the creep rate had reached a minimum value of 0.0018 per cent per hr even though this sample was apparently still in first-stage creep. Increasing the stress level to 8000 psi resulted in an appreciable increase in the rate of deformation and rupture occurred in about $18 \mathrm{hr}$. As shown by the log-log plot of these data in Figure 27, the stress-rupture curve for unalloyed niobium is very flat.

Generally, the resistance to creep of all of the alloys tested at $1200 \mathrm{~F}$ and stresses to 20,000 psi was excellent. None of these alloys had a minimum creep rate greater than 0.0002 per cent per $\mathrm{hr}$. Indeed, four of the alloys $(12.6 \mathrm{a} / \mathrm{o}$ vanadium, 7.2 a/o molybdenum, 7.6 a/o vanadium- 2.3 a/o molybdenum, and 7.3 a/o vanadium$2.4 \mathrm{a} / \mathrm{o}$ titanium) showed no measurable creep after exposure periods up to $500 \mathrm{hr}$. Further, six of these seven alloys showed 0.2 per cent or less total plastic strain as a result of the creep exposures.

Similarly, of the six alloys tested at $30,000 \mathrm{psi}$ and $1200 \mathrm{~F}$, excellent resistance to creep was shown by all excepting the 46.8 a/o zirconium-5. 1 a/o titanium alloy. This alloy, which showed a superior ultimate tensile strength to the 12.6 a/o vanadium alloy at $1200 \mathrm{~F}$ (Table 20), ruptured with 3 per cent elongation after a 68-hr exposure to 30,000 psi while the vanadium alloy had a total deformation of only 0.2 per cent after a 500-hr exposure. The poor creep strength of this alloy appears attributable to its high zirconium content; i.e., at $1200 \mathrm{~F}$, the alloy behaves much like a zirconium-base alloy.

The creep resistance of the two ternary alloys containing titanium was excellent although both of these alloys showed tendencies to undergo more pronounced deformation on loading than any of the other alloys tested (note the creep-deformation curve for the 7.3 a/o vanadium-2.4 a/o titanium alloy in Figure 26 ). In one instance, a sample of the 11.2 a/o titanium- 3.2 a/o molybdenum alloy was inadvertently loaded to $8000 \mathrm{psi}$ over its 22,000-psi yield strength at $1200 \mathrm{~F}$. Although this sample elongated 2. 4 per cent on loading, no measurable creep subsequently occurred in a period of $210 \mathrm{hr}$. This suggested that the creep resistance of this alloy would be quite amenable to strengthening by cold working. As proof of this hypothesis, another sample of this alloy was exposed to the same stress (30,000 psi) at $1200 \mathrm{~F}$ after an 18 per cent cold reduction. As indicated in Table 23, the cold-worked sample underwent a total plastic strain of less than 0.1 per cent and had an estimated minimum creep rate of 0.00003 per cent per $h r$ after a 138-hr exposure.

Of all of the alloys tested, the most outstanding resistance to creep deformation was shown by the 12.6 a/o vanadium alloy. This is evident from comparison of the data in Table 24, which shows good creep strength is retained in this alloy at temperatures to $1380 \mathrm{~F}$ and stresses to $40,000 \mathrm{psi}$. 
TABLE 23. CREEP-DEFORMATION AND -RUPTURE

\begin{tabular}{|c|c|c|c|c|c|c|c|c|}
\hline \multirow[b]{3}{*}{ Alloy } & \multirow{3}{*}{$\begin{array}{c}\text { Alloy Content } \\
\text { (Balance Niobium), } \\
\text { a/o }\end{array}$} & \multirow[b]{3}{*}{$\begin{array}{c}\text { Temperature, } \\
\text { F }\end{array}$} & \multirow[b]{3}{*}{$\begin{array}{c}\text { Stress, } \\
\text { psi }\end{array}$} & \multirow{3}{*}{$\begin{array}{c}\text { Elongation } \\
\text { on Loading, } \\
\text { per cent }\end{array}$} & \multicolumn{4}{|c|}{ Deformation Properties } \\
\hline & & & & & \multicolumn{2}{|c|}{$\begin{array}{c}\text { Total } \\
\text { Deformation }\end{array}$} & \multicolumn{2}{|c|}{$\begin{array}{c}\text { Creep } \\
\text { Deformation(b) } \\
\end{array}$} \\
\hline & & & & & Per Cent & $\begin{array}{c}\text { Time, } \\
\text { hr }\end{array}$ & Per Cent & $\begin{array}{c}\text { Time, } \\
\text { hr }\end{array}$ \\
\hline \multirow[t]{12}{*}{$T P-37$} & $100 \mathrm{Nb}$ & 1200 & 6,000 & 0.15 & 1 & 0.38 & 0.1 & 0.02 \\
\hline & & & & & 2 & 3.9 & 0.2 & 0.05 \\
\hline & & & & & 5 & 90 & 0.5 & 0.12 \\
\hline & & & & & 5.8 & 265 & 0.75 & 0.30 \\
\hline & & & & & & & 1.0 & 0.56 \\
\hline & & 1200 & 8,000 & 0.5 & 1 & 0.12 & 0.1 & 0.02 \\
\hline & & & & & 2 & 0.44 & 0.2 & 0.04 \\
\hline & & & & & 5 & 1.3 & 0.5 & 0.12 \\
\hline & & & & & & & 0.75 & 0.20 \\
\hline & & & & & & & 1.0 & 0.28 \\
\hline & & & & & & $\cdot$ & 2.0 & 0.60 \\
\hline & & & & & & & 5.0 & 1.40 \\
\hline \multirow[t]{12}{*}{ NL-2 } & $12.6 \mathrm{~V}$ & 1200 & 20,000 & 0.12 & 0.15 & 0.35 & 0.03 & 0.35 \\
\hline & & & & & 0.16 & 0.4 & 0.04 & 0.4 \\
\hline & & & & & 0.16 & 500 & 0.04 & 500 \\
\hline & & & 30,000 & 0.24 & 0.24 & 0.1 & 0.0 & 1 \\
\hline & & & & & 0.25 & 100 & 0.005 & 100 \\
\hline & & 1200 & 30,000 & 0.20 & 0.21 & 1 & 0.01 & 1 \\
\hline & & & & & 0.21 & 500 & 0.01 & 500 \\
\hline & & 1380 & 40,000 & 0.35 & 0.35 & 1 & 0.05 & 21 \\
\hline & & & & & 0.38 & 10 & 0.1 & 41 \\
\hline & & & & & 0.59 & 100 & 0.2 & 84 \\
\hline & & & & & 0.78 & 200 & 0.5 & 248 \\
\hline & & & & & 0.94 & 307 & 0.59 & 307 \\
\hline \multirow[t]{6}{*}{ NL-11 } & $7.6 \mathrm{~V}$ & 1200 & 20,000 & 0.28 & 0.30 & 1 & 0.05 & 92 \\
\hline & & & & & 0.32 & 10 & 0.07 & 254 \\
\hline & & & & & 0.33 & 100 & 0.08 & 303.9 \\
\hline & & & & & 0.34 & 200 & & \\
\hline & & & & & 0.36 & 300 & & \\
\hline & & & & & 0.36 & 303.9 & & \\
\hline \multirow[t]{9}{*}{ NL -12} & $8.7 \mathrm{~V}-0.26 \mathrm{~N}$ & 1200 & 20,000 & 0.27 & 0.30 & 1 & 0.05 & 120 \\
\hline & & & & & 0.30 & 10 & 0.07 & 168 \\
\hline & & & & & 0.31 & 100 & 0.08 & 256.4 \\
\hline & & & & & 0.34 & 200 & & \\
\hline & & & & & 0.35 & 256.4 & & \\
\hline & & 1200 & 30,000 & 0.48 & 0.50 & 1 & 0.05 & 6 \\
\hline & & & & & 0.54 & 10 & 0.10 & 130 \\
\hline & & & & & 0.57 & 100 & 0.12 & 142.2 \\
\hline & & & & & 0.58 & 142.2 & & \\
\hline \multirow[t]{4}{*}{ NL-13 } & $7.3 \mathrm{~V}-2.4 \mathrm{Ti}$ & 1200 & 20,000 & 0.60 & 0.80 & 1 & 0.10 & 0.1 \\
\hline & & & & & 0.86 & 10 & 0.20 & 0.5 \\
\hline & & & & & 0.86 & 220.4 & 0.26 & 3 \\
\hline & & & & & & & 0.26 & 220.4 \\
\hline
\end{tabular}


PROPERTIES OF SELECTED NIOBIUM-BASE ALLOYS(a)

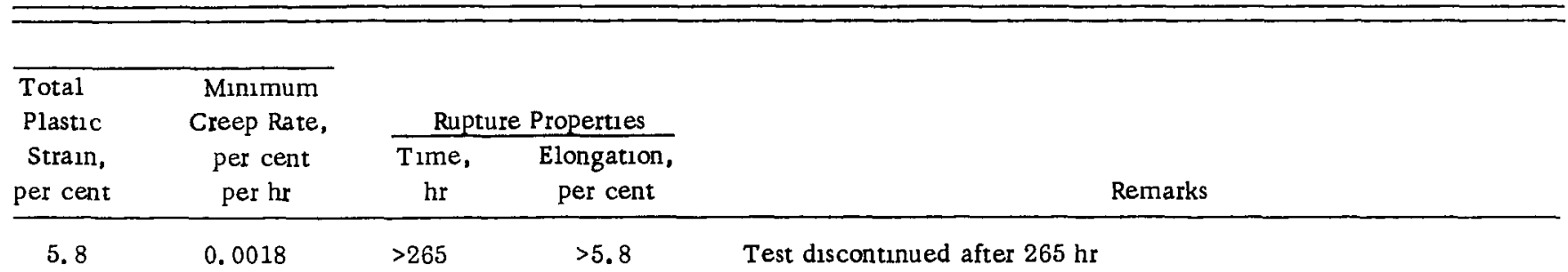

$\begin{array}{llll}17.9 & 3.0 & 10.1 & 17.9\end{array}$

\begin{tabular}{|c|c|c|c|c|}
\hline 0.04 & N11 & $>500$ & -- & Stress increased to $30,000 \mathrm{psi}$ after $500 \mathrm{hr}$ \\
\hline 0.1 & 0.00005 & $>100$ & -- & $\begin{array}{l}\text { Stress increased to } 40,000 \text { psi after } 100 \mathrm{hr} \text { and held for an additional } \\
145 \mathrm{hr} \text {, giving a total deformation of } 0.3 \text { per cent in } 745 \mathrm{hr}\end{array}$ \\
\hline 0.03 & $\mathrm{~N}$ ll & $>500$ & -- & Test dıscontinued after $500 \mathrm{hr}$ \\
\hline 0.7 & 0.0016 & $>307$ & - & Test discontunued after $307 \mathrm{hr}$ \\
\hline
\end{tabular}

$\begin{array}{lllll}0.24 & 0.00021 & >303.9 & - & \text { Test discontinued after } 303.9 \mathrm{hr}\end{array}$

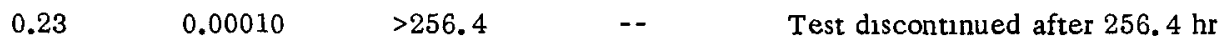

$0.40 \quad 0.00022 \quad>142.2 \quad--\quad$ Test discontınued $142.2 \mathrm{hr}$
0.74
Nil
$>220.4$
Test discontinued after $220.4 \mathrm{hr}$ 
TABLE 23.

\begin{tabular}{|c|c|c|c|c|c|c|c|c|}
\hline \multirow[b]{3}{*}{ Alloy } & \multirow{3}{*}{$\begin{array}{c}\text { Alloy Content } \\
\text { (Balance Niobium), } \\
\text { a/o }\end{array}$} & \multirow[b]{3}{*}{$\begin{array}{c}\text { Temperature, } \\
\text { F }\end{array}$} & \multirow[b]{3}{*}{$\begin{array}{c}\text { Stress, } \\
\text { psi }\end{array}$} & \multirow{3}{*}{$\begin{array}{l}\text { Elongation } \\
\text { on Loading, } \\
\text { per cent }\end{array}$} & \multicolumn{4}{|c|}{ Deformation Properties } \\
\hline & & & & & \multicolumn{2}{|c|}{$\begin{array}{c}\text { Total } \\
\text { Deformation } \\
\end{array}$} & \multicolumn{2}{|c|}{$\begin{array}{c}\text { Creep } \\
\text { Deformation(b) }\end{array}$} \\
\hline & & & & & Per Cent & $\begin{array}{c}\text { Time, } \\
\text { hr }\end{array}$ & Per Cent & $\begin{array}{c}\text { Time, } \\
\mathrm{hr}\end{array}$ \\
\hline \multirow[t]{8}{*}{ NL-14 } & $7.6 \mathrm{~V}-2.3 \mathrm{Mo}$ & 1200 & 20,000 & 0.13 & 0.14 & 1 & 0.05 & 200 \\
\hline & & & & & 0.15 & 10 & 0.05 & 261.6 \\
\hline & & & & & 0.17 & 100 & & \\
\hline & & & & & 0.18 & 261.6 & & \\
\hline & & 1200 & 30,000 & 0.26 & 0.27 & 1 & 0.05 & $40^{\circ}$ \\
\hline & & & & & 0.29 & 10 & 0.05 & 117.3 \\
\hline & & & & & 0.31 & 45 & & \\
\hline & & & & . & 0.31 & 117.3 & & \\
\hline \multirow[t]{20}{*}{ NL-3 } & $7.2 \mathrm{Mo}$ & 1200 & 20,000 & 0.12 & 0.12 & 1 & 0 & 1 \\
\hline & & & & & 0.12 & 500 & 0 & 500 \\
\hline & & & 30,000 & 0.25 & 0.25 & 1 & 0.01 & 4 \\
\hline & & & & & 0.30 & 56 & 0.02 & 11 \\
\hline & & & & & 0.30 & 172 & 0.05 & 56 \\
\hline & & & & & & & 0.05 & 172 \\
\hline & & 1200 & 30,000 & 0.19 & 0.19 & 1 & 0.01 & 5 \\
\hline & & & & & 0.21 & 10 & 0.02 & 10 \\
\hline & & & & & 0.30 & 100 & 0.05 & 33 \\
\hline & & & & & 0.35 & 200 & 0.10 & 88 \\
\hline & & & & & 0.39 & 300 & 0.20 & 300 \\
\hline & & & & & 0.41 & 400 & 0.23 & 432 \\
\hline & & & & & 0.42 & 432 & & \\
\hline & & 1380 & 30,000 & 0.24 & 0.4 & 1 & 0.2 & 1.5 \\
\hline & & & & & 0.5 & 2 & 0.5 & 5.8 \\
\hline & & & & & 1 & 9.2 & 1 & 12.8 \\
\hline & & & & & 2 & 23.2 & 2 & 26.7 \\
\hline & & & & & 5 & 65.6 & 5 & 69 \\
\hline & & & & & 7.6 & 100 & 10 & 134 \\
\hline & & & & & 10 & 131 & & \\
\hline \multirow[t]{14}{*}{ NL -7} & $11.2 \mathrm{Ti}-3.2 \mathrm{Mo}$ & 1200 & 20,000 & 0.25 & 0.25 & 1 & 0.01 & 10 \\
\hline & & & & & 0.26 & 10 & 0.02 & 73 \\
\hline & & & & & 0.28 & 100 & 0.05 & 267 \\
\hline & & & & & 0.30 & 200 & 0.08 & 500 \\
\hline & & & & & 0.31 & 300 & • & \\
\hline & & & & & 0.32 & 400 & & \\
\hline & & & & & 0.33 & 500 & & \\
\hline & & 1200 & 30,000 & 2.41 & 2.41 & 1 & 0 & 1 \\
\hline & & & & & 2.41 & 210 & 0 & 210 \\
\hline & & & 35,000 & 3.82 & -- & - & -- & - \\
\hline & & 1200 & 30,000 & 0.17 & 0.20 & 1 & 0.01 & 0.5 \\
\hline & . & & & & 0.22 & 40 & 0.02 & 1 \\
\hline & & & & & 0.22 & 138 & 0.05 & 40 \\
\hline & & & & & & & 0.05 & 138 \\
\hline
\end{tabular}


(Continued)

\begin{tabular}{|c|c|c|c|c|}
\hline \multirow{2}{*}{$\begin{array}{l}\text { Total } \\
\text { Plastic } \\
\text { Strain, } \\
\text { per cent }\end{array}$} & \multirow{2}{*}{$\begin{array}{l}\text { Minımum } \\
\text { Creep Rate, } \\
\text { per cent } \\
\text { per hr }\end{array}$} & \multicolumn{2}{|c|}{ Rupture Properties } & \multirow[b]{2}{*}{ Remarks } \\
\hline & & $\begin{array}{c}\text { Time } \\
\text { hr }\end{array}$ & $\begin{array}{l}\text { Elongation, } \\
\text { per cent }\end{array}$ & \\
\hline 0.06 & Nıl & $>261.6$ & -- & Test discontinued after $261.6 \mathrm{hr}$ \\
\hline 0.13 & N11 & $>117.3$ & -- & Test discontınued after $117.3 \mathrm{hr}$ \\
\hline 0 & Nil & $>500$ & -- & Stressed increased to $30,000 \mathrm{ps} 1$ after $500 \mathrm{hr}$ \\
\hline 0.12 & $\mathrm{~N} 11$ & $>172$ & -- & $\begin{array}{l}\text { Test discontinued after total time of } 672 \mathrm{hr} \text { with a total deformation } \\
\text { of } 0.3 \text { per cent }\end{array}$ \\
\hline 0.24 & 0.00012 & $>432$ & -- & Test discontınued after $432 \mathrm{hr}$ \\
\hline 23 & 0.066 & 177.3 & 23 & \\
\hline 0.21 & 0.00010 & $>500$ & -- & Test discontinued after $500 \mathrm{hr}$ \\
\hline 2.2 & Nil & $>210$ & -- & $\begin{array}{l}\text { Stress increased to } 35,000 \text { psi after } 210 \mathrm{hr} \text { and held for an additional } \\
120 \mathrm{hr} \text { giving a total deformation of } 3.8 \text { per cent }\end{array}$ \\
\hline 3.6 & -- & $>210$ & & \\
\hline 0.05 & 0.00003 & $>138$ & -- & $\begin{array}{l}\text { Sample initially cold rolled to an } 18 \text { per cent reduction; test discon- } \\
\text { tinued after } 138 \mathrm{hr}\end{array}$ \\
\hline
\end{tabular}


TABLE 23.

\begin{tabular}{|c|c|c|c|c|c|c|c|c|}
\hline \multirow[b]{3}{*}{ Alloy } & \multirow{3}{*}{$\begin{array}{c}\text { Alloy Content } \\
\text { (Balance Niobium), } \\
\text { a/o }\end{array}$} & \multirow[b]{3}{*}{$\begin{array}{c}\text { Temperature, } \\
\text { F }\end{array}$} & \multirow[b]{3}{*}{$\begin{array}{l}\text { Stress, } \\
\text { psi }\end{array}$} & \multirow{3}{*}{$\begin{array}{l}\text { Elongation } \\
\text { on Loading, } \\
\text { per cent }\end{array}$} & \multicolumn{4}{|c|}{ Deformation Properties } \\
\hline & & & & & \multicolumn{2}{|c|}{$\begin{array}{c}\text { Total } \\
\text { Deformation }\end{array}$} & \multicolumn{2}{|c|}{$\begin{array}{c}\text { Creep } \\
\text { Deformation(b) } \\
\end{array}$} \\
\hline & & & & & Per Cent & $\begin{array}{c}\text { Time, } \\
\text { hr }\end{array}$ & Per Cent & $\begin{array}{c}\text { Time, } \\
\text { hr }\end{array}$ \\
\hline \multirow[t]{10}{*}{$\mathrm{NL}-4$} & $46.8 \mathrm{Zr}-5.1 \mathrm{Ti}$ & 1200 & 30,000 & 0.26 & 0.3 & 1 & 0.05 & 7.5 \\
\hline & & & & & 0.3 & 5 & 0.10 & 19.6 \\
\hline & & & & & 0.5 & 42.9 & 0.20 & 37.6 \\
\hline & & & & & 0.75 & 56.5 & 0.50 & 56.9 \\
\hline & & & & & 1.0 & 62.9 & 0.75 & 63.1 \\
\hline & & & & & & & 1.0 & 68.0 \\
\hline & & 1200 & 40,000 & 0.37 & 0.37 & 0.1 & 0.05 & 3.1 \\
\hline & & & & & 0.38 & 1 & 0.10 & 5.9 \\
\hline & & & & & 0.40 & 2 & & \\
\hline & & & & & 0.50 & 7.7 & & \\
\hline
\end{tabular}

(a) All alloys initially vacuum annealed $1 \mathrm{hr}$ at $2730 \mathrm{~F}$ excepting alloys $\mathrm{NL}-11$ through $\mathrm{NL}-14$, which were annealed at $2190 \mathrm{~F}$. (b) Creep deformation defined as total deformation minus elongation on loading. 
(Contınued)

\begin{tabular}{|c|c|c|c|c|}
\hline \multirow{2}{*}{$\begin{array}{l}\text { Total } \\
\text { Plastic } \\
\text { Strain, } \\
\text { per cent }\end{array}$} & \multirow{2}{*}{$\begin{array}{c}\text { Minımum } \\
\text { Creep Rate, } \\
\text { per cent } \\
\text { per hr }\end{array}$} & \multicolumn{2}{|c|}{ Rupture Propertıes } & \multirow[b]{2}{*}{ Remarks } \\
\hline & & $\begin{array}{c}\text { Time, } \\
\text { hr }\end{array}$ & $\begin{array}{c}\text { Elongation, } \\
\text { per cent }\end{array}$ & \\
\hline 3 & 0.0035 & 68.3 & 3 & \\
\hline 0.5 & 0.18 & -- & -- & Falled in grips after $7.7 \mathrm{hr}$ with total deformation of 0.5 per cent \\
\hline
\end{tabular}


T ABLE 24. COMPARISON OF CREEP-DEFORMATION PROPERTIES OF NIOBIUM ALLOYS

\begin{tabular}{|c|c|c|c|c|c|}
\hline \multirow[b]{2}{*}{ Alloy } & \multirow[b]{2}{*}{$\begin{array}{c}\text { Alloy Content } \\
\text { (Balance Niobium), } \\
\text { a/o }\end{array}$} & \multirow{2}{*}{$\begin{array}{c}\text { Total } \\
\text { Deformation } \\
\text { in } 100 \mathrm{Hr} \\
\text { per cent }\end{array}$} & \multicolumn{2}{|c|}{ Total Plastic Strain } & \multirow[b]{2}{*}{$\begin{array}{c}\text { Minimum } \\
\text { Creep Rate, } \\
\text { per cent per hr }\end{array}$} \\
\hline & & & $\begin{array}{c}\text { Time of } \\
\text { Test, } \\
\text { hr }\end{array}$ & $\begin{array}{c}\text { Strain, } \\
\text { per cent }\end{array}$ & \\
\hline \multicolumn{6}{|c|}{$1200 \mathrm{~F}, 20,000 \mathrm{PSI}$} \\
\hline NL-3 & $7.2 \mathrm{Mo}$ & 0.1 & 500 & $<0.1$ & Nil \\
\hline NL-2 & $12.6 \mathrm{~V}$ & 0.2 & 500 & $<0.1$ & Nil \\
\hline NL-14 & $7.6 \mathrm{~V}, 2.3 \mathrm{Mo}$ & 0.2 & 262 & $<0.1$ & Nil \\
\hline NL-7 & $11.2 \mathrm{Ti}, 3.2 \mathrm{Mo}$ & 0.3 & 500 & 0.2 & 0.0001 \\
\hline NL-12 & $8.7 \mathrm{~V}, 0.26 \mathrm{~N}$ & 0.3 & 256 & 0.2 & 0.0001 \\
\hline NL-11 & $7.6 \mathrm{~V}$ & 0.3 & 304 & 0.2 & 0.0002 \\
\hline NL-13 & $7.3 \mathrm{~V}, 2.4 \mathrm{Ti}$ & 0.9 & 220 & 0.7 & Nil \\
\hline \multicolumn{6}{|c|}{$\underline{1200 \mathrm{~F}, 30,000 \mathrm{PSI}}$} \\
\hline $\mathrm{NL}-2$ & $12.6 \mathrm{~V}$ & 0.2 & 500 & $<0.1$ & Nil \\
\hline$N L-3$ & $7.2 \mathrm{Mo}$ & 0.3 & 432 & 0.2 & 0.0001 \\
\hline NL-14 & $7.6 \mathrm{~V}, 2.3 \mathrm{Mo}$ & 0.3 & 117 & 0.1 & Nil \\
\hline NL-12 & $8.7 \mathrm{~V}, 0.26 \mathrm{~N}$ & 0.6 & 142 & 0.4 & 0.0002 \\
\hline NL-7 & $11.2 \mathrm{Ti}, 3.2 \mathrm{Mo}$ & 2.4 & 210 & 2.2 & Nil \\
\hline NL-4 & $46.8 \mathrm{Zr}, 5.1 \mathrm{Ti}$ & $>3$ & 68 & 3 & $0.18^{(a)}$ \\
\hline \multicolumn{6}{|c|}{$1380 \mathrm{~F}, 30,000 \mathrm{PSI}$} \\
\hline NL-3 & $7.2 \mathrm{Mo}$ & 7.6 & 177 & 23 & $0.066^{(b)}$ \\
\hline \multicolumn{6}{|c|}{$1380 \mathrm{~F}, 40,000 \mathrm{PSI}$} \\
\hline NL-2 & $12.6 \mathrm{~V}$ & 0.6 & 307 & 0.7 & 0.0016 \\
\hline
\end{tabular}

(a) Ruptured in $68 \mathrm{hr}$.

(b) Ruptured in $177 \mathrm{hr}$. 


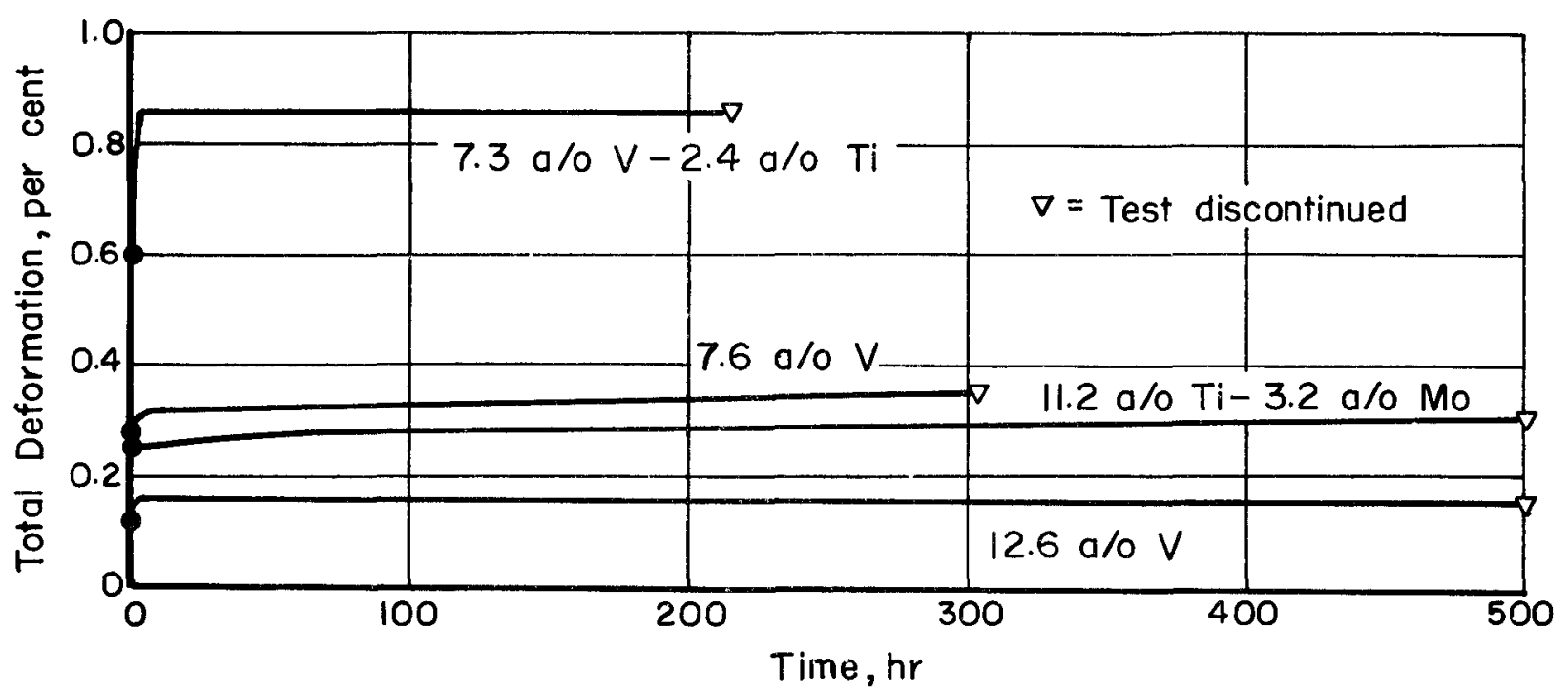

a. Tested at 20,000 PSI

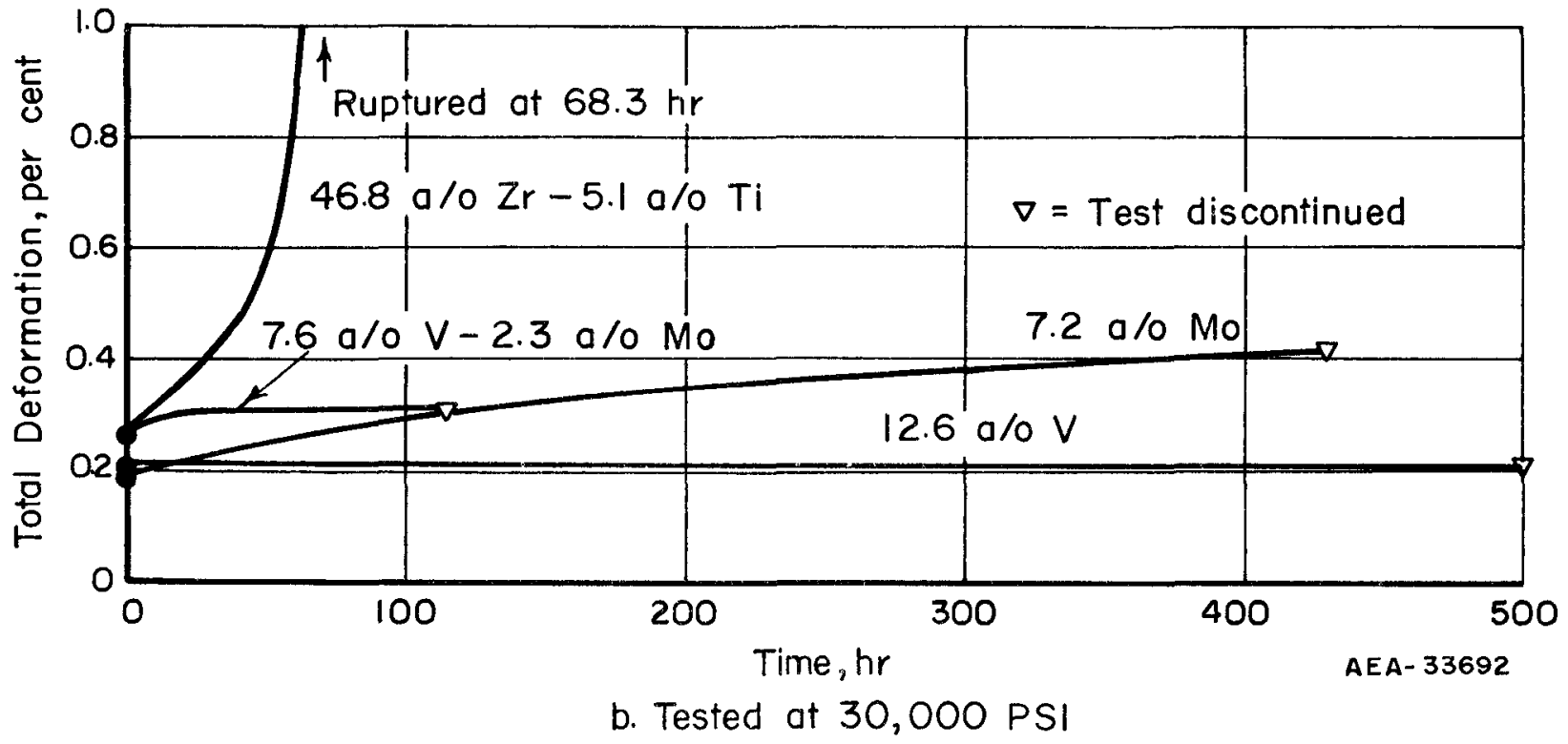

FIGURE 26. CREEP-DEFORMATION CURVES OF VARIOUS NIOBIUM-BASE ALLOYS AT $1200 \mathrm{~F}$ 


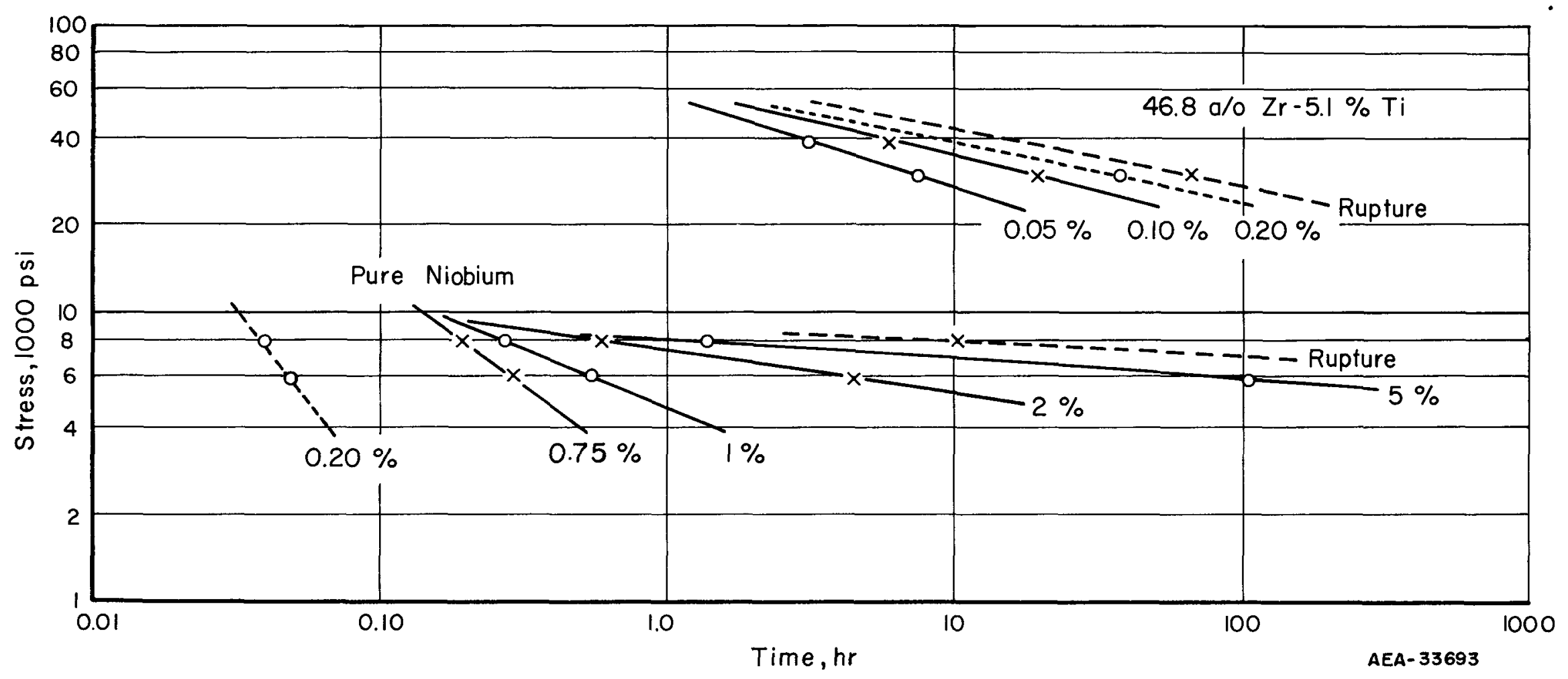

FIGURE 27. CREEP DEFORMATION OF RECRYSTALLIZED NIOBIUM AND NIOBIUM-46.8 a/o ZIRCONIUM-5. 1 a/o TITANIUM ALLOY AT $1200 \mathrm{~F}$ 
TABLE 25. EFFECT OF CREEP EXPOSURE ON THE ROOM-TEMPERAT URE TENSILE PROPERTIES OF SELECTED NIOBIUM-BASE ALLOYS

\begin{tabular}{|c|c|c|c|c|c|}
\hline \multirow[b]{2}{*}{ Alloy } & \multirow[b]{2}{*}{$\begin{array}{c}\text { Alloy Content } \\
\text { (Balance Niobium), } \\
\text { a/o }\end{array}$} & \multirow[b]{2}{*}{ History of Material(a) } & \multicolumn{3}{|c|}{ Room-Temperature Tensile Properties } \\
\hline & & & $\begin{array}{l}0.2 \text { Per Cent Offset } \\
\text { Yield Strength, } \\
1000 \mathrm{psi}\end{array}$ & $\begin{array}{l}\text { Ultimate } \\
\text { Strength, } \\
1000 \mathrm{psi}\end{array}$ & $\begin{array}{l}\text { Elongation } \\
\text { in } 1 \text { In. , } \\
\text { per cent }\end{array}$ \\
\hline \multirow[t]{3}{*}{$\mathrm{TP}-37$} & $100 \mathrm{Nb}$ & Annealed $1 \mathrm{hr}$ at $2730 \mathrm{~F}$ & 20.5 & 26 & 28 \\
\hline & & Strained 5.8 per cent in $265 \mathrm{hr}$ at $1200 \mathrm{~F}$ under & & & \\
\hline & & $6,000 \mathrm{psi} ;$ annealed $1 \mathrm{hr}$ at $2190 \mathrm{~F}$ & 24 & 29 & 23 \\
\hline \multirow[t]{7}{*}{ NL-2 } & $12.6 \mathrm{~V}$ & Annealed $1 \mathrm{hr}$ at $2730 \mathrm{~F}$ & 79 & 97 & 24 \\
\hline & & Strained 0.3 per cent in $745 \mathrm{hr}$ at $1200 \mathrm{~F}$ under & & & \\
\hline & & $40,000 \mathrm{psi}$; annealed $1 \mathrm{hr}$ at $2190 \mathrm{~F}$ & 81 & 100 & 31 \\
\hline & & Strained 0.2 per cent in $500 \mathrm{hr}$ at $1200 \mathrm{~F}$ under & & & \\
\hline & & 30,000 psi & 75 & 81 & 1 \\
\hline & & Strained 0.9 per cent in $307 \mathrm{hr}$ at $1380 \mathrm{~F}$ under & & & \\
\hline & & $40,000 \mathrm{psi}$ & 80 & 82 & 1 \\
\hline \multirow[t]{4}{*}{ NL-3 } & $7.2 \mathrm{Mo}$ & Annealed $1 \mathrm{hr}$ at $2730 \mathrm{~F}$ & 63 & 77 & 20 \\
\hline & & Strained 0.3 per cent in $672 \mathrm{hr}$ at $1200 \mathrm{~F}$ under & & & \\
\hline & & $30,000 \mathrm{psi} ;$ annealed $1 \mathrm{hr}$ at $2190 \mathrm{~F}$ & 64 & 78 & 20 \\
\hline & & $\begin{array}{l}\text { Strained } 0.4 \text { per cent in } 432 \mathrm{hr} \text { at } 1200 \mathrm{~F} \text { under } \\
30,000 \mathrm{psi} \text {; surface ground to remove } 2 \text { mils } \\
\text { of metal }\end{array}$ & 57 & 69 & 18 \\
\hline \multirow[t]{5}{*}{ NL-7 } & $11.2 \mathrm{Ti}-3.2 \mathrm{Mo}$ & Annealed 1 hr at $2730 \mathrm{~F}$ & 57 & 67 & 35 \\
\hline & & Strained 0.3 per cent in $500 \mathrm{hr}$ at $1200 \mathrm{~F}$ under & & & \\
\hline & & $20,000 \mathrm{psi}$ & 58 & 60 & 1 \\
\hline & & Strained 3.8 per cent in $330 \mathrm{hr}$ at $1200 \mathrm{~F}$ under & & & \\
\hline & & 35,000 psi & -- & 68 & 1 \\
\hline
\end{tabular}

(a) Annealing treatments and creep exposure conducted in vacuum. 
Several of the discontinued creep test samples were tensile tested at room temperature to check the effect of creep exposure on the subsequent room-temperature behavior. When brittle behavior was observed in two each of the $12.6 \mathrm{a} / \mathrm{o}$ vanadium and 11.2 a/o titanium-3. 2 a/o molybdenum alloys tested "as-removed" from the creep apparatus, several experiments were performed to investigate this behavior. Hardness measurements on shoulder sections of the brittle room-temperature test samples were made and showed no increases indicative of gross contamination. Subsequently, additional room-temperature tensile tests were carried out on these and other alloy samples after (1) vacuum annealing at $2190 \mathrm{~F}$ to remove possible strain-hardening effects, or (2) simply surface grinding the creep test sample to remove 2 mils of metal. The results of all of these tests are summarized in Table 25.

As shown, in ail cases, either surface grinding or subsequent vacuum annealing restored the original room-temperature properties to the alloys. These data indicate that the embrittlement observed in the original samples resulted from contamination of a thin surface layer of the alloys during creep exposure. Removal of the layer (either by grinding or diffusing it into the base metal) resulted in no detriment to the tensile properties.

\section{CONCLUSIONS}

On the basis of this research, the following conclusions are offered regarding the potential usefulness of niobium and niobium alloys in pressurized-water thermal reactors:

(1) High-purity niobium offers more resistance to corrosion by 600 and $680 \mathrm{~F}$ water and $750 \mathrm{~F}$ steam than commercial-purity niobium. However, neither grade is as resistant to attack as zirconium. Hence, niobium must be alloyed in order to obtain adequate corrosion resistance and improved strength for pressurized-water applications.

(2) Binary and ternary additions of chromium, iron, molybdenum, titanium, vanadium, and zirconium significantly improve the corrosion resistance of niobium. In binary combinations, the effects of titanium, vanadium, and zirconium are most outstanding.

(3) The fabricability of the vanadium and titanium alloys, in the ranges required for good corrosion resistance, is good to excellent while that for the zirconium alloys is marginal.

(4) Many binary and ternary alloys show as low or lower weight changes, after comparable exposure times, in $680 \mathrm{~F}$ water and $750 \mathrm{~F}$ steam than Zircaloy-2. However, of these alloys, only a ternary 28.2 a/o titanium6.1 a/o chromium alloy and alloys containing 45 a/o or more zirconium develop a dense, adherent tarnish film.

(5) Base-metal purity does not appear to have a significant effect on the corrosion behavior of niobium alloys. 
(6) The effects of alloying additions on the behavior of niobium in hot water are similar to their effects on the behavior of niobium in hot air. Hence, oxidation appears to be the primary reaction involved in both media and the alloying mechanism for improving the resistance of niobium to both media appears similar.

(7) Most of the niobium-base alloys tested show strength far superior to that of zirconium and Zircaloy-2 at temperatures from 900 through $1200 \mathrm{~F}$.

(8) At temperatures through $1200 \mathrm{~F}$, the tensile strength and creep resistance of binary vanadium and molybdenum alloys, at levels down to about $7.5 \mathrm{a} / \mathrm{o}$, and ternary alloys of molybdenum, titanium, and vanadium are excellent. Comparably, at $1200 \mathrm{~F}$, the creep resistance of high-zirconium-content alloys is quite low.

(9) On the basis of thermal-neutron-absorption cross section, fabricability, corrosion resistance, and hot strength, vanadium offers the greatest advantages in improving the properties of niobium for pressurized-water thermal-reactor applications.

\section{REFERENCES}

(1) Griess, J. C., et al., Solution Corrosion Group Quarterly Report, for the period ending April 30, 1957, CF 57-455 (Unclassified).

(2) Ivanov, O., and Grigorovich, V., "Structure and Properties of Zirconium Alloys", Paper No. 2046 presented at the 2nd International Conference on the Peaceful Uses of Atomic Energy, Geneva, Switzerland (September 1-13, 1958).

(3) Klopp, W. D., Maykuth, D. J., Sims, C. T., and Jaffee, R. I. , "Oxidation and Contamination Reactions of Niobium and Niobium Alloys", Battelle Memorial Institute, Report No. BMI-1317 (February 3, 1959).

(4) Brauer, G., Z. anorg. u. allgem. Chem., 248, 1-31 (1941).

(5) Metallurgy of Zirconium, edited by B. Lustman and F. Kerze, McGraw-Hill Book Company, New York (1955), p 634.

(6) Ang, C. Y., "Activation Energies and Diffusion Coefficients of Oxygen and Nitrogen in Niobium and Tantalum", Acta Met., 1,123 (March, 1953).

(7) Laves, F., "Crystal Structure and Atomic Size", Theory of Alloy Phases, American Society for Metals, Cleveland (1956), p 124.

(8) Coughlin, J. P., "Contributions to the Data on Theoretical Metallurgy", U. S. Bur. Mines Bull. 542 (1954).

(9) Kubaschewski, O., and Hopkins, B. E., Oxidation of Metals and Alloys, Butterworths, London (1953). 